\title{
CRESCIMENTO E RECRUTAMENTO DE MACRO E MICRONUTRIENTES NO PERÍODO DE QUATRO ANOS \\ PELA Hevea brasiliensis CLONE Fx 3864 NA REGIÃO DE RIO BRANCO, AC
}

IRAE AMARAL GUERRINI

Orientador: HENRIQUE PAULO HAAG

Dissertação apresentada à Escola Superior de Agricultura "Luiz de Queiroz", da Universidade de São Paulo, para obtenção do título de Mestre em Agronomia. Área de Concentração: Solos $\theta$ Nutrição de Plantas.

PIRACICABA

Estado de São Paulo - Brasil

Setembro, 1983 
O FERE $\{0$ aos meus pais,

Rubens e Maria Anésia,

e aos meus irmãos,

Ivan, Ilmar, Ivail e Isis,

bênçãos de Deus na minha vida.

DEDICO a minha querida noiva, Ivana. 
- ao Eng? Agr? Dr. Heroldo Weber, do PLANALSUCAR - Campos, RJ, pe la grande ajuda na coleta de material;

- a todas as pessoas que conheci durante o Curso e que participaram direta ou indiretamente na minha formação e, em especial,aos amigos que ganhei;

- a Antonio Roberto Formaggio, MiZton Kanashiro e José Francisco Trevisan, amigos de inestimável valor;

- ao Pe. Vitório, de Campinas, SP, pela amizade, apoio espiritual e principal responsāvel pela minha saūde durante os ültimos anos:

- ao Colégio Salesiano Dom Bosco de Piracicaba; um dos responsäveis pela minha formação moral e espiritual e no qual passei bons momentos de minha vida;

- ao meu irmāo e amigo, Ivan Amaraz Guerrini, pelo apoio constante, sugestōes valiosas e por ter estado sempre disponível em co laborar neste trabalho. 


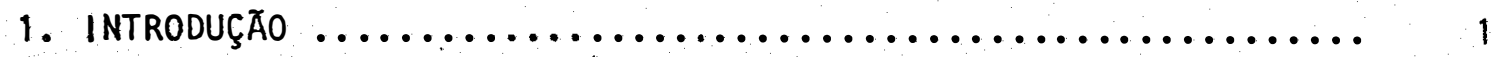

2. REVISÃO DE LITERATURA ............................ 3

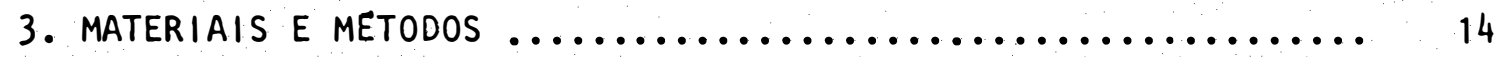

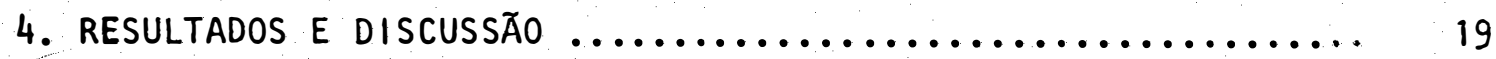

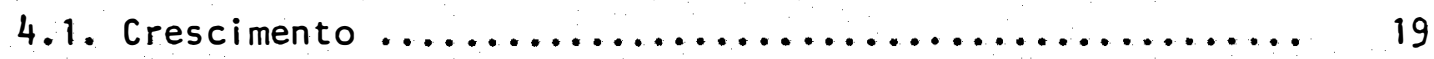

4.2. Extração de Macronutrientes $\ldots \ldots \ldots \ldots \ldots \ldots \ldots \ldots \ldots . \ldots \ldots$

4.2.1. Nitrogênio ............................ 24

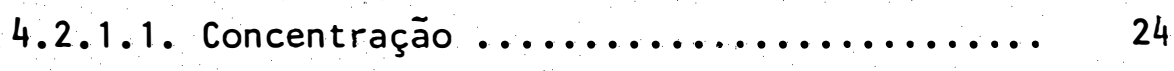

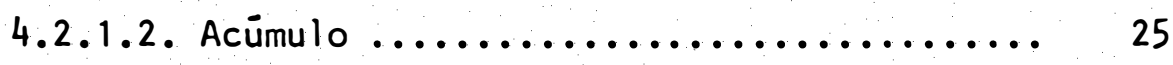

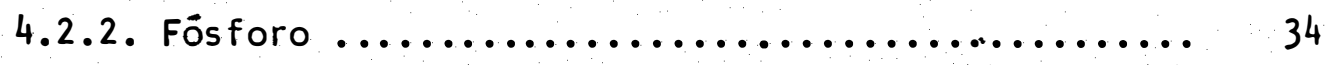

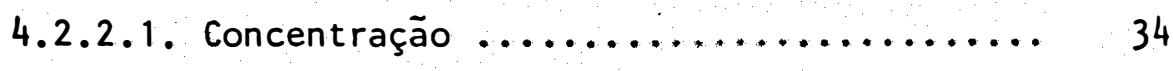

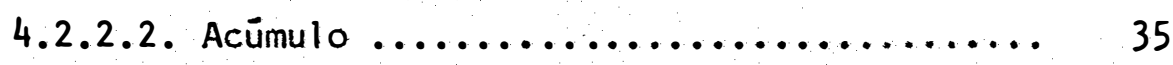

4.2.3. Potässio ......................... 39

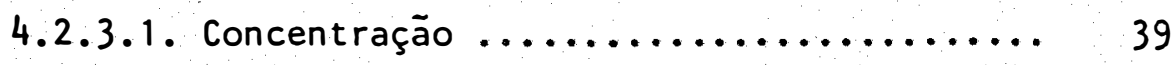

4.2.3.2. Acümulo .................... 40

4.2.4. Cálcio ........................... 45

4.2.4.1. Concentração ................... 45

4.2.4.2. Acümulo ...................... 46

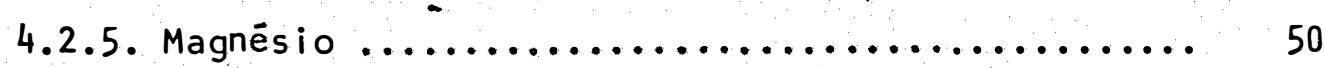

4.2.5.1. Concentração ............... 50

4.2.5.2. Acümulo ...................... 51

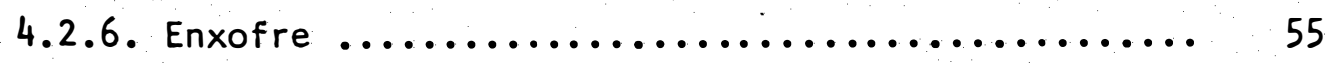

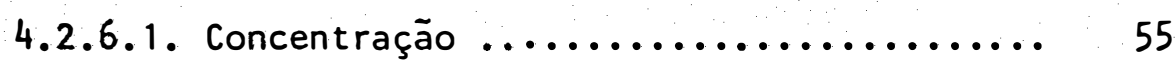

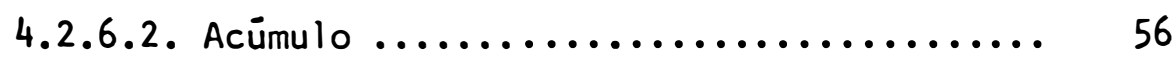


Pägina

4.3. Extração de Micronutrientes ................... 61

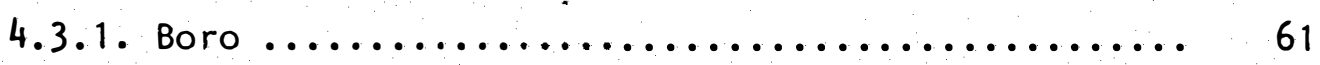

4.3.1.1. Concentração ................ 61

4.3.1.2. Acümulo .................... 62

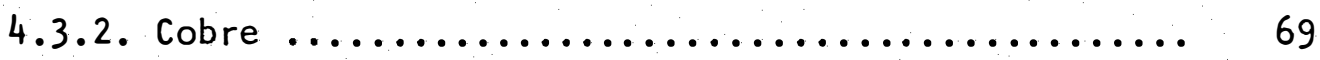

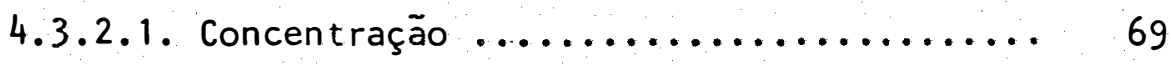

4.3.2.2. Acúmulo ...................... 70

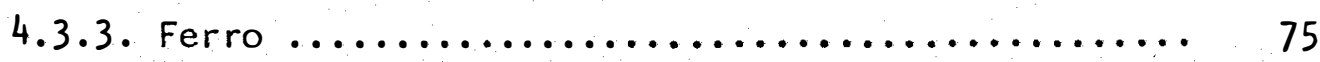

4.3.3.1. Concentração ................. 75

4.3.3.2. Acúmulo ...................... 76

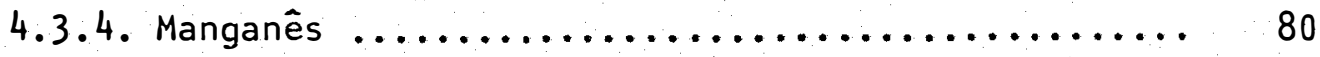

4.3.4.1. Concentração ................ 80

4.3.4.2. Acümulo $\ldots \ldots \ldots \ldots \ldots \ldots \ldots \ldots \ldots \ldots . . . \ldots 1$

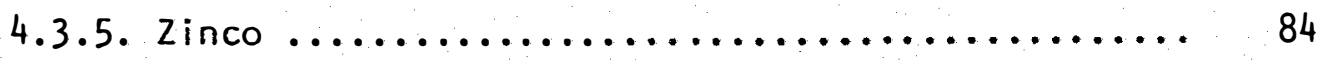

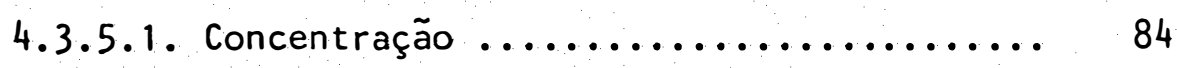

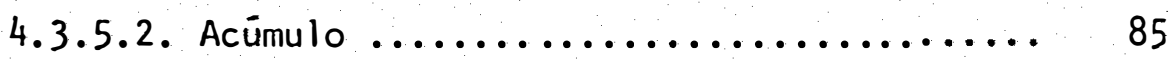

4.4. Extração de nutrientes pela cobertura verde e nutrientes contidos na cobertura morta ................. 89

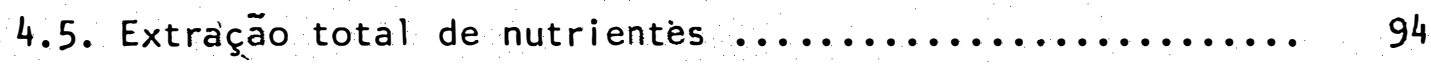

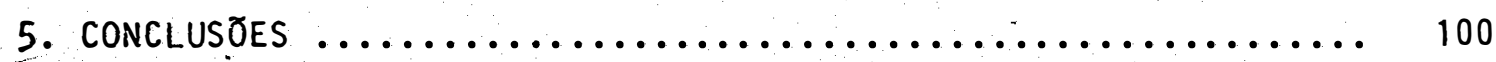

6. LITERATURA CITADA ............................ 103 


\section{CRESCIMENTO E RECRUTAMENTO DE MACRO E MICRONUTRIENTES \\ NO PERTODO DE QUATRO ANOS PELA Hevea brasiziensis \\ CLONE FX 3864 NA REGIĀO DE RIO BRANCO, AC}

IRAE AMARAL GUERRINI

ORIENTADOR: HENRIQUE PAULO HAAG

RESUMO

Com o objetivo de obter dados referentes ao crescimento e concentração e acúmulo de macro e micronutrientes em função dá idade da planta, foram coletadas amostras de folhas, galhos secos, ponta e base de galhos primärios, e ponta, meio e base do tronco de plantas de seringueira, clone $F \times 3864$ com 1,0 a 4,0 anos de idade em plantações situadas sobre Latossol Vermelho-Amarelotextura argilosa na ärea: da BONAL S/A, localizada na região de Rio Branco, AC. Coletou-se, também, amostras da leguminosa (Pueraria phaseoloides) e cobertura morta a fim de se avaliar a extração total e a ciclagem de nutrientes no sistema.

Os resultados obtidos mostraram que:

- O maior incremento no crescimento ocorreu a partir do terceiro ano.

- As maiores concentrações de nutrientes, exceto para o cobre, ocorreram nas folhas. 
- A extração de nutrientes pela seringueira, por hectare, no quarto ano, foi a seguinte: $\mathrm{N}-24,54 \mathrm{~kg}, \mathrm{P}-1,82 \mathrm{~kg}, \mathrm{~K}-18,29 \mathrm{~kg}$, $\mathrm{Ca}-11,07 \mathrm{~kg}, \mathrm{Mg}-5,29 \mathrm{~kg}, \mathrm{~S}-1,88 \mathrm{~kg}, \mathrm{~B}-29,4 \mathrm{~g}, \mathrm{Cu}-18,3 \mathrm{~g}, \mathrm{Fe}-$ $140,4 \mathrm{~g}, \mathrm{Mn}-436,7 \mathrm{~g}$ e $\mathrm{Zn}-52,2 \mathrm{~g}$.

- A extração de nutrientes pela leguminosa, por hectare, no quarto ano, foi a seguinte: $\mathrm{N}-43,32 \mathrm{~kg}, \mathrm{P}-4,14 \mathrm{~kg}, \mathrm{~K}-79,64 \mathrm{~kg}$, $\mathrm{Ca}-21,34 \mathrm{~kg}, \mathrm{Mg}-8,60 \mathrm{~kg}, \mathrm{~S}-3,19 \mathrm{~kg}, \mathrm{~B}-127,4 \mathrm{~g}, \mathrm{Cu}-60,5 \mathrm{~g}, \mathrm{Fe}-$ $3131,8 \mathrm{~g}, \mathrm{Mn}-1277,4 \mathrm{~g}$ e $\mathrm{Zn}-140,2 \mathrm{~g}$.

- A extração total de macronutrientes pelo sistema, em or dem decrescente, foi a seguinte: $\mathrm{N}>\mathrm{K}>\mathrm{Ca}>\mathrm{Mg}>\mathrm{S}>\mathrm{P}$, enquanto que para os micronutrientes foi: $\mathrm{Fe}>\mathrm{Mn}>\mathrm{Zn}>\mathrm{B}>\mathrm{Cu}$.

- A quantidade e porcentagem de nutrientes que será devol vida ao solo através da cobertura morta, é a seguinte: $\mathrm{N}-95,78 \mathrm{~kg}(58,5 \%)$, $\mathrm{P}-3,55 \mathrm{~kg}(37,3 \%), \mathrm{K}-27,20 \mathrm{~kg}(21,7 \%), \mathrm{Ca}-41,98 \mathrm{~kg}(56,4 \%), \mathrm{Mg}-$ $16,56 \mathrm{~kg}(54,4 \%), \mathrm{S}-5,32 \mathrm{~kg}(51,2 \%), \mathrm{B}-189,2 \mathrm{~g}(54,7 \%), \mathrm{Cu}-106,5 \mathrm{~g}$ $(57,5 \%), \mathrm{Fe}-31673,3 \mathrm{~g}(90,7 \%), \mathrm{Mn}-5007,9 \mathrm{~g}(74,5 \%)$ e $\mathrm{Zn}-207,0 \mathrm{~g}$ $(51,8 \%)$. 
GROWTH OF THE Hevea brasiziensis CLONE FX 3864

AND ABSORPTION OF MACRO AND MICRONUTRIENTS

IN A FOUR YEAR PERIODSATRIO BRANCO, AC, BRAZIL

IRAE AMARAL GUERRIN |

ADVISER: HENRIQUE PAULO HAAG

\section{SUMMARY}

Primary objective of this work was to study the growth, and concentration and accumulation of nutrients (macro and micro) on the Hevea brasiliensis plants, at various ages.

Leaves, stems and branches of Rubber Tree, clone

Fx 3864, from òne year up to four years old were collected from a plantation located at the BONAL S.A. farm at Rio Branco. The soil under the forest was classified as. a heavy texture Red-Yellow Latosol. Samples of the legume (Pueraria phaseoloides) and litter were also collected, in order to estimate total nutrient extracion and cycling in the system.

Results obtained showed that:

- Highest growth increment occured from the third year on.

- The leaves had the highest nutrient concentration, with the exception for the copper. 
- During the fourth year, nutrient extraction by Rubber Tree, per hectare, was: $\mathrm{N}-24.54 \mathrm{~kg}, \mathrm{P}-1.82 \mathrm{~kg}, \mathrm{~K}-18.29 \mathrm{~kg}$, Ca -11.07 $\mathrm{kg}, \mathrm{Mg}-5.29 \mathrm{~kg}, \mathrm{~S}-1.88 \mathrm{~kg}, \mathrm{~B}-29.4 \mathrm{~g}, \mathrm{Cu}-18.3 \mathrm{~g}, \mathrm{Fe}-140.4 \mathrm{~g}$, $M n-436.7 \mathrm{~g}$ and $\mathrm{Zn}-52.2 \mathrm{~g}$.

- During the fourth year, nutrient extraction by legume, per hectare, was: $\mathrm{N}-43.32 \mathrm{~kg}, \mathrm{P}-4.14 \mathrm{~kg}, \mathrm{~K}-79.64 \mathrm{~kg}, \mathrm{Ca}-21.34 \mathrm{~kg}$, $\mathrm{Mg}-8.60 \mathrm{~kg}, \mathrm{~S}-3.19 \mathrm{~kg}, \mathrm{~B}-127.4 \mathrm{~g}, \mathrm{Cu}-60.5 \mathrm{~g}, \mathrm{Fe}-3131.8 \mathrm{~g}, \mathrm{Mn}-$ $1277.4 \mathrm{~g}$ and $\mathrm{Zn}-140.2 \mathrm{~g}$.

- Total macronutrients were absorbed in the following decreasing order: $\mathrm{N}>\mathrm{K}>\mathrm{Ca}>\mathrm{Mg}>\mathrm{S}>\mathrm{P}$, while micronutrients had the following order: $\mathrm{Fe}>\mathrm{Mn}>\mathrm{Zn}>\mathrm{B}>\mathrm{Cu}$.

- Part of the nutrients absorbed by systems was recycled, with the following quantities and percentages returning to the soil: $\mathrm{N}-95.78 \mathrm{~kg}(58.5 \%), P-3.55 \mathrm{~kg}(37.3 \%), \mathrm{K}-27.20 \mathrm{~kg}(21.7 \%), \mathrm{Ca}-41.98$ $\mathrm{kg}(56.4 \%), \mathrm{Mg}-16.56 \mathrm{~kg}(54.4 \%), \mathrm{S}-5.32 \mathrm{~kg}(51.2 \%), \mathrm{B}-189.2 \mathrm{~g}(54.7 \%)$, $\mathrm{Cu}-106.5 \mathrm{~g}(57.5 \%), \mathrm{Fe}-31673.3 \mathrm{~g}(90.7 \%), \mathrm{Mn}-5007.9 \mathrm{~g}(74.5 \%)$ and $\mathrm{Zn}-207.0 \mathrm{~g}(51.8 \%)$. 


\section{INTRODUÇÃO}

A seringueira (Hevea brasiliensis), origināria da Amazônia, jā foi a cultura de maior interesse econômico para o Brasil, na épo ca em que nossopaís era o maior produtor mundial de borracha. Entretanto, com o decorrer do tempo, passou a ser importador do produto, apesar de possuir todas as condições para o bom desenvolvimento e expansão da cultura.

objetivo de tornar o País, novamente, auto-suficiente e, se possível, ex portador desse produto, o Brasil criou O PROBOR - Programa de Incentivo à Produção de Borracha Natural, o qual vem possibilitando o plantiode se ringueira em muitas regiões do nosso territörio.

Entretanto, a falta de maiores pesquisas sobre o desenvol vimento e nutrição da espécie para as nossas condições, tem levado ao aparecimento de problemas de ordem nutricional nos plantios, podendo, inclusive, afetar as metas propostas pelo governo. 
A marcha de absorção de nutrientes pela seringueira foi realizada com os seguintes objetivos:

- analisar o crescimento da planta através da produção de matéria seca e determinar o período de maior crescimen to;

- determinar a. concentração dos macro e micronutrientes, nas diversas partes da planta, em função das idades;

- determinar a quantidade de macro e micronutrientes extraída pela.planta, em função das idades;

- determinar a quantidade de macro e micronutrientes extraída pela leguminosa, em função das idades;

- determinar a quantidade de macro e micronutrientes con tida na cobertura morta, em função das idades. 


\section{REVISAOO DE LITERATURA}

A análise do crescimento e do conteüdo total de nutrientes de uma planta em seus diferentes estádios de crescimento è um requerimento básico para a resolução de problemas nutricionais. Apesar disso, esse tipo de estudo ainda não foi realizado para a seringueira aqui no Brasil, sendo que praticamente toda literatura conseguida é estrangeira.

Dick (1939), citado por SHORROCKS (1965a), publicou dados, embora sem detalhes, a respeito do conteūdo de nutrientes de uma ärvore de aproximadaìente trinta e cinco anos de idade, com um peso de matéria seca de cerca de $3590 \mathrm{~kg}$. Outros pesquisadores obtiveram dados do peso de matéria seca da seringueira, como Constable (1955) e Beaulfils e Nguyen (1957), citados por SHORROCKS (1965a), mas também não detalharam as análises químicas das árvores nas diferentes idades. OTOUL (1960) e Temple ton (1964), citado por SHORROCKS (1965a), realizaram trabalhos semelhan tes aos dos autores anteriores, analisando o peso seco de apenas uma ārvore, por idade. OTOUL (1960) obteve um peso de $24 \mathrm{~kg}$ ( 3 anos), $271 \mathrm{~kg}$ (6 anos), $619 \mathrm{~kg}(10$ anos) e. $1197 \mathrm{~kg}$ (22 anos), enquantoTempleton (1964) 
citado por SHORROCKS (1965a), obteve um peso total de $199 \mathrm{~kg}(5$ anos, clone $P R$ 107) e $239 \mathrm{~kg}(5,5$ anos, clone PR 107). No mesmo trabalho, OTOUL (1960), estudando o sistema radicular da seringueira em um Latossol Vermelho Amarelo contendo $30 \%$ de argila, em Yangambi (ex-Congo Belga), obte ve que esse $\vec{e}$ muito profundo, atingindo $3,75 \mathrm{~m}$ aos 6 anos de idade, alëm de explorar um grande volume de solo, com o comprimento lateral variando de 4,20 a 6,50 m na mesma idade.

SHORROCKS (1965a), fazendo uma anālise da distribuição de matēria verde e seca nos diferentes örgãos da planta em relação à idade para o clone RRIM 501 (445 plantas/ha), obteve os resultados constantes na Tabela 1. 0 autor mostra que a porcentagem de matéria seca das foIhas è de $8,8 \%$ no primeiro ano, atíngindo um mäximo de $13,1 \%$ no terceiro ano e caindo para $6,9 \%$ no quarto ano, ocorrendo um declínio gradual até atingir $3,8 \%$ aos 10 anos. A matéria seca para os outros órgãos foi assim distribuída, do primeiro ao quarto ano: 12,7 a $7,0 \%$ nos galhos jovens,ze ro a $41,7 \%$ nos galhos velhos com casca, 43,0 a $28,7 \%$ no tronco, com o peso da casca variando de 9 a $13 \%$ do peso total do tronco (em qualquer idade), e 35,6 a $15,8 \%$ nas raízes. Para as árvores de quatro a oi to anos de idade, as raízes apresentaram um peso de cerca de $15 \%$ do peso seco to tal da ārvore, sendo que Dyck (1939), citado por SHORROCKS (1965a), obte ve resultados semelhantes $(15,2 \%)$. As raízes das ārvores com idade acima de oito anos não foram pesadas; nestes casos, SHORROCKS (1965a) estimou os pesos verde e seco da parte aérea acima do solo como sendo $85 \%$ do peso total da ārvore (com raíz).

LIM (1977), num trabalho equivalente ao de SHORROCKS (1965a), 


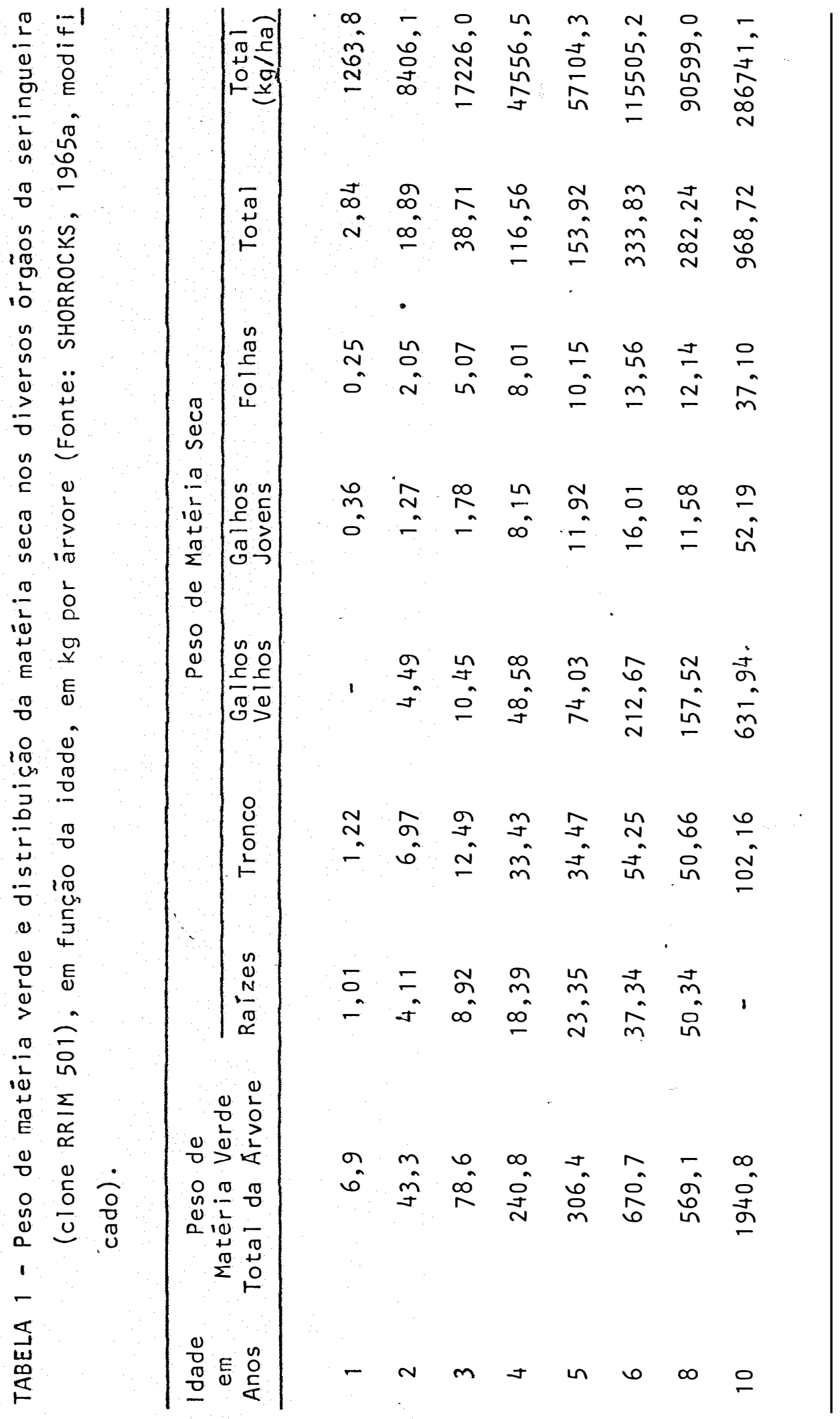


esţudou a produção de matēria seca pelo clone RRIM 600, em dois tipos di ferentes de solo, com uma densidade de 380 plantas/ha, no decorrer dos a nos. Ele verificou que para a série de solo Munchong, a produção de matēria seca foi inicialmente baixa, mas aumentou progressivamente a partir do oitavo ano. A produção total de matēria seca, em 15 anos, foi es timada em $230000 \mathrm{~kg}$ para a sērie Munchong e somente $180000 \mathrm{~kg}$ para a série Rengam. A taxa média dessa produção foi de $15600 \mathrm{~kg} / \mathrm{ha} / \mathrm{ano}$ para a sērie Munchong e $12600 \mathrm{~kg} / \mathrm{ha} / \mathrm{ano}$ para a sērie Rengam.

As principais regiões que cultivam a seringueira em nosso País possuem solos relativamente pobres em nutrientes. Segundo MALAVOLTA et alii (1974), a seringueira é uma planta que se adapta a solos relativamente pobres e, apesar disso, responde bem à aplicação de fertilizan tes e extrai quantidades elevadas de nutrientes. E possível que essa planta consiga suprir as suas deficiencias nesses solos emvirtude de pos suir um sistema radicular muito desenvolvido.

Dijkman (1961), citado por MALAVOLTA et alii (1974), encontrou que, àlém do älto consumo de nutrientes destinados à formação dos diferentes örgãos, $1000 \mathrm{~kg}$ de borracha seca (látex desidratado) contêm $7,5 \mathrm{~kg}$ de $\mathrm{N}, 3,0 \mathrm{~kg}$ de $\mathrm{P}_{2} \mathrm{O}_{5}$ e $6,0 \mathrm{~kg}$ de $\mathrm{K}_{2} 0$. Segundo $\mathrm{O}$ autor,essas quantidades são baixíssimas quando comparadas com as que são consumidas para a formação dos diferentes órgãos vegetais. Nair (1957), citado por MALAVOLTA et alii. (1974), comprova essa afirmação apresentando o consumo acumulado de N, P e K extraídos pela seringueira em dois países diferentes. Na Java Ocidental, o consumo de nutrientes pelas seringueiras adul tas ē de $2497 \mathrm{~kg} / \mathrm{ha}$ de $\mathrm{N}, 3745 \mathrm{~kg} / \mathrm{ha}$ de $\mathrm{P}_{2} \mathrm{O}_{5}$ e $2996 \mathrm{~kg} / \mathrm{ha}$ de $\mathrm{K}_{2} \mathrm{O}$, e na 
Maläsia, o consumo è de $2334 \mathrm{~kg} / \mathrm{ha}$ de $\mathrm{N}, 733 \mathrm{~kg} / \mathrm{ha}$ de $\mathrm{P}_{2} \mathrm{O}_{5}$ e $2634 \mathrm{~kg} / \mathrm{ha}$ de $\mathrm{K}_{2} \mathrm{O}$.

HOELZ et alii (s.d.) compararam a extração de nutrientes entre a seringueira e algumas culturas e notaram que as necessidades minerais da seringueira, na maturidade, são praticamente 10 vezes menores do que as do dendê e muito menores que as de outras culturas tropicais. Mainstone (1963), citado por MALAVOLTA et alii (1974), também obteve resultados que indicam ser muito baixo o consumo de nutrientes necessários para produzir $1000 \mathrm{~kg}$ de borracha seca por ano.

Estudando a absorção de nutrientes pela seringueira, em fun ção da idade, para uma densidade de 445 plantas/ha do clone RRIM 501 , SHORROCKS (1965a) obteve os resultados constantes da Tabela 2 . Como se pode notar, há uma grande absorção de cälcio pela seringueira, perdendo apenas para o nitrogênio a partir do quinto ano. Segundo o autor, cerca de 30 a $50 \%$ dessa quantidade estão depositados na casca do tronco e galhos, e é possível que nem todo cälcio absorvido seja essencial para o crescimento da ārvore, havendo necesisidade de mais estudos com relação a esse nutriente. Com respeito aos micronutrientes, o conteüdo destes é mui to baixo. Aquele que aparece em maior quantidade é o manganês, seguido do ferro, zinco, cobre, boro e, finalmente, o molibdênio, que contribui com apenas alguns gramas.

No mesmo trabalho, SHORROCKS (1965a) apresenta a concentração mëdia de nutrientes no tronco, galhos, galhos verdes folhas e raí zes, e os resultados encontram-se na Tabela 3. 0 autor afirma que não hou ve relação entre as concentrações de nutrientes nos diversos örgãos e a $i$ 


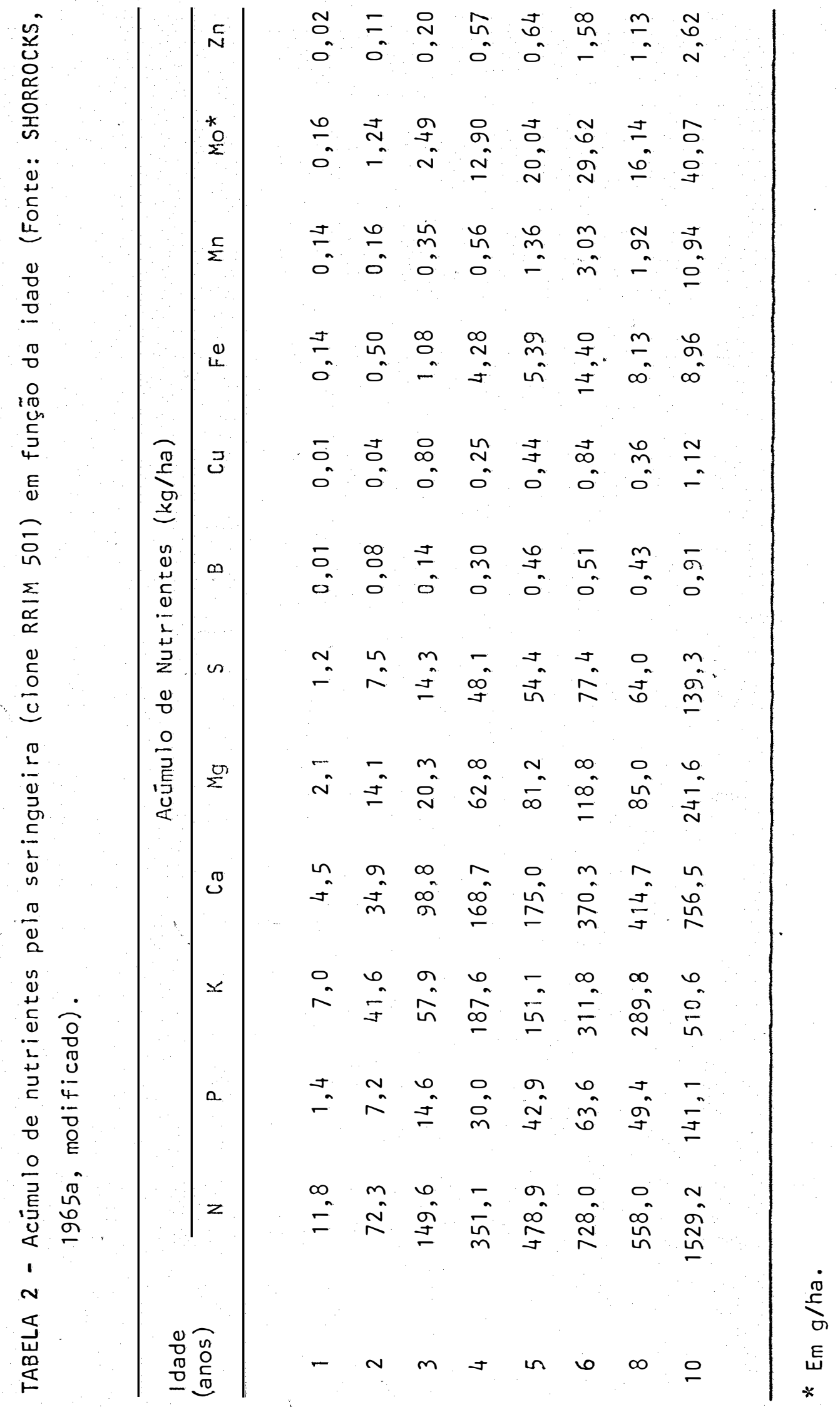


TABELA 3 - Mëdias das concentrações de nutrientes nos diversos órgãos da seringueira. (Fonte: SHORROCKS, 1965a, modificado).

\begin{tabular}{|c|c|c|c|c|c|}
\hline $\begin{array}{l}\text { Elemento } \\
\text { Nutriente }\end{array}$ & Raizes & Tronco & Galhos & Galhos Verdes & Folthas \\
\hline $\mathrm{N} \%$ & 0,62 & 0,45 & 0,45 & 0,93 & 2,79 \\
\hline $\mathrm{P} \%$ & 0,09 & $0,0.0$ & 0,05 & 0,11 & 0,18 \\
\hline $\mathrm{K} \%$ & 0,31 & 0,25 & 0,27 & 0,63 & 0,90 \\
\hline $\mathrm{Mg} \%$ & 0,15 & 0,12 & 0,09 & 0,12 & 0,24 \\
\hline $\mathrm{Ca} \%$ & 0,31 & 0,33 & 0,30 & 0,82 & 0,86 \\
\hline $\mathrm{S} \%$ & 0,06 & 0,06 & 0,06 & 0,12 & 0,22 \\
\hline Mn ppm & 17 & 25 & 26 & 90 & 211 \\
\hline Fe ppm & 233 & 30 & 37 & 71 & 182 \\
\hline B ppm & 4 & 4 & 3 & 6 & 29 \\
\hline $\mathrm{Zn} \mathrm{ppm}$ & 15 & 16 & 8 & 12 & 23 \\
\hline $\mathrm{Cu} \mathrm{ppm}$ & 4 & 3 & 4 & 11 & 11 \\
\hline Mo ppm & 0,20 & 0,20 & 0,14 & 0,16 & 0,17 \\
\hline
\end{tabular}


dade da planta. As concentrações dos vărios nutrientes nos galhos verdes foram maiores que as dos galhos restantes e tronco. As concentrações de nutrientes nas folhas também excederam as dos galhos restantes e tron co. Concentrações muito altas de ferro foram encontradas nas raízes, e segundo o autor, possivelmente isso é devido à imobilização desse elemen to e também à superfície contaminada que não foi removida pela água.

PUSHPARAJAH (1977), fazendo um estudo com plantas jovens de seringueira, crescidas em casa-de-vegetação e sob doses altas de adubo nitrogenado, obteve, entre outras, as seguintes concentrações mëdias de nitrogênio nas folhas: 4,22\% para o clone GL $1, \quad 3,83 \%$ para o clone RRIM 701 e 3,59\% para o clone PB 86. Nesse mesmo trabalho, o autor estü dou a interação clone-nutriente em ärvores maduras plantadas sob a sērie de solo Rengam (um típico Paleudult), obtendo as seguintes concentrações médias de nutrientes nas folhas: fósforo $(0,211 \%$ para os clones AVROS, 0,194\% para os clones PR e $0,226 \%$ para os clones RRIM), potássio $(1,14 \%$ para os clones AVROS, 1,12\% para os clones PR e 1,15\% para os clones RRIM), cálcio $(0,75 \%$ para os clones AVROS, $0,76 \%$ para os clones PR e $0,78 \%$ para.os clones RRIM) e magnésio (0,246\% para os clones AVROS, $0,241 \%$ para os clones PR e $0,214 \%$ para os clones RRIM).

LIM (1977), num trabalho equivalente ao de SHORROCKS (1965a), estudou a absorção de nutrientes pelo clone RRIM-600 nas séries de solo Rengam e Munchong, com uma densidade de 380 plantas/ha, com o decorrer dos anos. As taxas de absorção de nutrientes durante os seis primeiros anos de crescimento foram: 80 a $90 \mathrm{~kg} / \mathrm{ha} / \mathrm{ano}$ de nitrogênio, 8 a $11 \mathrm{~kg} /$ ha/ano de fósforo, 53 a $73 \mathrm{~kg} / \mathrm{ha} /$ ano de potássio, 70 a $75 \mathrm{~kg} / \mathrm{ha} / \mathrm{ano}$ de 
călcio, 12 a $15 \mathrm{~kg} / \mathrm{ha} / \mathrm{ano}$ de magnésio e 4 a $5 \mathrm{~kg} / \mathrm{ha} / \mathrm{ano}$ de enxofre. Nos dez anos subsequentes, às taxas de imobilização foram: 14 a $16 \mathrm{~kg} / \mathrm{ha} / \mathrm{ano}$ de nitrogênio, 6 a 8 kg/ha/ano de fósforo, 53 a 74 kg/ha/ano de potās sio, 77 a $87 \mathrm{~kg} / \mathrm{ha} / a n o$ de cälcio, 7 a $20 \mathrm{~kg} / \mathrm{ha} / a n o$ de magnēsio e 5 a 6 $\mathrm{kg} / \mathrm{ha} / \mathrm{ano}$ de enxofre.

Para os dois tipos de solo, de acordo com o autor, houve poucas diferenças no conteúdo total de nitrogênio, fósforo, cálcio e en xofre acumulado na ārvore. Entretanto, os conteúdos totais de potássio e magnēsio foram bem diferentes. As ärvores plantadas na série Munchong imobilizaram maiores quantidades de potāssio e magnésio do que as plantadas na série Rengam.

Com relação aos micronutrientes, as ärvores na série Mun chong apresentaram uma maior quantidade de manganês, zinco, cobre e boro do que as plantadas na série Rengam.

No mesmo trabalho, LIM (1977) estudou a distribuição de nu trientes nos diferentes órgãos da planta, obtendo que cerca de 30 a $65 \%$ de nitrogênio, 44 a $68 \%$ de fösforo, 52 a $65 \%$ de potássio, 46 a $60 \%$ de cāl cio e 38 a $48 \%$ de magnésio estão localizados nos galhos. Exceto para as folhas, que tinham 21 a $42 \%$ de nitrogênio, as outras partes da ärvore apresentaram baixas proporções de nutrientes em relação aos galhos.

A distribuição desses nutrientes nos tecidos da casca e madeira dos galhos também foi estudada pelo autor. Exceto para o cálcio, a madeira apresentou uma alta proporção de nutrientes, ou seja, 30 a 50\% de nitrogênio, 50 a $70 \%$ de fósforo, 30 a $50 \%$ de potässioe 50 a $70 \%$ de mag 
nésio. Os tecidos da casca apresentaram um conteúdo excepcional de cälcio.

Embora essa grande quantidade de nutrientes absorvida pela seringueira esteja imobilizada na ärvore, TAN (1975) mostrou que esses nutrientes podem ser considerados como reservas armazenadas. Ele ve rificou que a concentração de nutrientes na casca e na madeira cai para cerca de 15 a $20 \%$ do valor original na ëpoca da refoliação anual, atingindo novamente o nível inicial apōs esse período. A diminuição de nutrientes nos tecidos da casca e raiz é seguida de um aumento na concen tração de nutrientes nos galhos verdes, mostrando um movimento de nutrientes das reservas da casca e madeira para tecidos em crescimento ativo. Geralmente, espera-se que a concentração de nutrientes nos tecidos da cas ca e madeira sejam maiores em ärvores bem adubadas. 0 autor também afi ma que uma quantidade considerável de nutrientes é armazenada nas folhas. Esses nutrientes retornam ao solo durante o ciclo anual de refoliação, mas a taxa de liberação pelas folhas é relativamente baixa, particularmente para o nitrogênio e fø̈sforo. Deste modo, a adição de nutrientes, atravês da queda das folhas do ano corrente, só estará disponível para absorção durante os anos subsequentes.

Diversos autores têm demonstrado que o nivel de nutrientes nas folhas podem ser afetados por diferentes fatores. Por exemplo, GUHA e NARAYANAN (1969) notaram que os conteúdos de nitrogênio, fósforo, e potăssio apresentam uma correlação linear negativa com a idade da foIha, enquanto que os conteúdos de cālcio e manganês mostraram uma cor- 
relação linear positiva. 0 conteüdo de magnésio não mostrou qualquer cor relação com a idade da folha. SHORROCKS (1965b) também obteve consideráveis variações de um mês para o outro nos conteūdos foliares de nitrogênio, cálcio e manganês, enquanto que as variações nos conteúdos de potás sio, magnésio e fósforo foram pequenas no período de agosto a dezembro (nas condições da Malásia). O autor obteve ainda que a quantidade de nu trientes na folha também depende da época de amostragem, indicando que essa prática deve ser realizada no periodo em que ocorre menores variações, ou seja, de agosto a dezembro, quando as folhas possuem cerca de 5 a 9 meses de idade. Resultados semelhantes foram obtidos por BOLLE JONES E RATNASINGAM (1.954) e BEAUFILS (1955). SHORROCKS (1962a e 1962b) mostrou que há diferença no conteüdo de nutrientes das folhas iluminadas e sombreadas, indicando as sombreadas como mais sensívèis e convenientes para serem amostradas, com fins de diagnose foliar.

PUSHPARAJAH (1977) obteve considerāveis diferenças no conteüdo de nutrientes das folhas para os diferentes clones, sugerindo como causa as variações no vigor, características de crescimento e látex removido.

Além de todos esses fatores de influência na quantidade de nutrientes das folhas, PUSHPARAJAH e TAN (1972) e PUSHPARAJAH (1977) citam diversos outros, como as propriedades químicas e físicas do solo, fatores de manejo do solo (tipo de cobertura, tipo e época de aplicação de fertilizante), produção e sistema de exploração e tipo de "cavalo" utilizado na enxertia. 


\section{MATERIAIS E METODOS.}

As plantas de seringueira (Hevea brasiliensis) utilizadas são do clone Fx 3864 (híbrido intraespecífico) e foram coletadas na propriedade do Seringal Bom Destino (BONAL S.A.), localizada no km 76 da Ro dovia BR-364, em Rio Branco, Estado do Acre.

Essa ărea foi levantada pelo Projeto RADAM (BRASIL, 1976) e enquadrada na Folha SC.19 Rio Branco, a qual é limitada pelos paralelos de $08^{\circ} 00^{\prime}$ e $11^{\circ} 00^{\prime} \mathrm{S}$ e meridianos de $66^{\circ} 00^{\prime}$ e $72^{\circ} 00^{\prime} \mathrm{WGr}$, abrangendo terras dos estados do Acre, Amazonas e Rondônia.

A ärea não apresenta grandes acidentes topogräficos, não alcançando cotas de $300 \mathrm{~m}$. 0 clima è quente e ümido. A elevada pluviosidade registrada é um dos fatores fortemente característicos dessa região que estā limitada pelas isoietas de $1750 \mathrm{~mm}$ e $2250 \mathrm{~mm}$. 0 período chuvoso praticamente se inicia em outubro, prolongando-se até abril ou maio. 0 primeiro trimestre do ano apresenta o maior acúmulo de chuvas. As temperaturas médias anuais apresentam variações limitadas pelas isotermas de $22^{\circ} \mathrm{C}$ e $26^{\circ} \mathrm{C}$. E frequente a ocorrência de ondas de frio no eixo 
sul-sudeste, com duração de 3 a 8 dias, onde a temperatura pode cair brus camente até $4^{\circ} \mathrm{C}$. 0 período mais quente fica compreendido entre os meses de agosto e outubro. A umidade relativa $\vec{e}$ bastante elevada e tem como li mites as isohigras de $85 \%$ e $90 \%$. 0 balanço hidrico acusa para a estação de Boca do Acre um mäximo de deficiência hídrica anual equivalente a $216 \mathrm{~mm}$ em solos arenosos na espessura de $0-60 \mathrm{~cm}$.

A ärea de cultivo da BONAL S.A. estä assentada primordial mente sobre um Latossol Vermelho Amarelo textura argilosa. As amostras de solo foram coletadas para as diferentes idades da planta e as suas características químicas estão apresentadas na Tabela 4.

0 clone utilizado foi o Fx 3864 , que tem como paternais os clo nes PB 86 e FB 38, e que, segundo a EMBRATER (1979), destaca-se em produtividade e desenvolvimento no sul da Bahia.

Foram coletadas plantas de 1 a 4 anos de idade, ao acaso, com seis repetiçães para cada idade (1 ärvore/repetição). As datas de plantio e de coleta são apresentadas na Tabela 5.

Essas plantas foram cultivadas num espaçamento de $8,0 \mathrm{~m} \times$ $2,8 \mathrm{~m}$, perfazendo um total de $446 \mathrm{plantas/ha,} \mathrm{e} \mathrm{receberam} \mathrm{adubação} \mathbb{N}-\mathrm{P}-\mathrm{K}$ atravēs da förmula 26-18-9, assim distribuída:

19. ano: $50 \mathrm{~g}$ da förmula com 3 aplicações $=150 \mathrm{~g} / \mathrm{planta}$

29 ano: $70 \mathrm{~g}$ da förmula com 3 aplicações $=210 \mathrm{~g} / \mathrm{planta}$

3ํ. ano: $100 \mathrm{~g}$ da förmula com 3 aplicaçües $=300 \mathrm{~g} / \mathrm{planta}$

4․ ano: $150 \mathrm{~g}$ da förmula com 3 aplicações $=450 \mathrm{~g} / \mathrm{planta}$ 
TABELA 4 - Anälise química do solo da ärea de cultivo da BONAL S.A.

\begin{tabular}{|c|c|c|c|c|}
\hline \multirow{2}{*}{ Características } & \multicolumn{4}{|c|}{ Solo correspondente a ärvores com idade de } \\
\hline & $\begin{array}{c}1 \text { ano } \\
\text { Bloco SW 29B }\end{array}$ & $\begin{array}{c}2 \text { anos } \\
\text { Bloco NW } 25\end{array}$ & $\begin{array}{l}3 \text { anos } \\
\text { Bloco SW } 17\end{array}$ & $\begin{array}{c}4 \text { anos } \\
\text { Bloco SW } 13\end{array}$ \\
\hline $\mathrm{pH}\left(1: 1\right.$ em $\left.\mathrm{H}_{2} 0\right)$ & 4,6 & 6,4 & 4,4 & 4,5 \\
\hline$C \%$ & 0,90 & 0,90 & 1,14 & 0,75 \\
\hline V\% & 31,60 & 85,33 & 22,86 & 24,52 \\
\hline & $-\cdots-\cdots$ & -.. emg / 1 & $\begin{array}{lllll} & 0 & g & \cdots\end{array}$ & 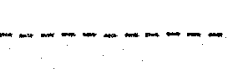 \\
\hline $\mathrm{PO}_{4}^{-3}$ & 0,02 & 0,23 & 0,06 & 0,01 \\
\hline$k^{+}$ & 0,36 & 0,56 & 0,28 & 0,13 \\
\hline $\mathrm{Ca}^{++}$ & 1,12 & 8,20 & 1,04 & 0,70 \\
\hline $\mathrm{Mg}^{++}$ & 0,96 & 1,95 & 0,72 & 0,73 \\
\hline $\mathrm{Al}^{+++}$ & 1,52 & 0,08 & $2, \grave{40}$ & 1,69 \\
\hline $\mathrm{H}^{+}$ & 5,20 & 1,84 & 6,88 & 4,80 \\
\hline $\mathrm{Na}^{+}$ & 0,02 & 0,07 & 0,03 & 0,01 \\
\hline CTC & 7,72 & 12,55 & 8,92 & 6,36 \\
\hline
\end{tabular}

(๘) $\mathrm{H}_{2} \mathrm{SO}_{4} 0,05 \mathrm{~N}$

TABELA 5 - Datas de plantio è de coleta para cada idade do clone Fx 3864.

\begin{tabular}{llll}
\hline Idade & Plantio & Quadra & Coleta \\
\hline 19 ano & março/80 & Bloco SW 29B & janeiro/81 \\
29 ano & janeiro/79 & Bloco NW 25 & janeiro/81 \\
3: ano & março/78 & Bloco SW 17 & janeiro/81 \\
4: ano & janeiro/77 & Bloco SW 13 & janeiro/81
\end{tabular}


Além dessa aplicação, as plantas do terceiro e quarto ano receberam $1 \mathrm{~kg}$ de hiperfosfato/planta.

Em 1980, todas as idades receberam $5 \mathrm{~g} / \mathrm{planta}$ de sulfa to de manganês.

A coleta das plantas foi realizada da seguinte maneira: cortou-se a planta na sua base, separando-se o "cavalo"; a parte aérea restante foi subdividida em:

1? ano: folha, tronco-ponta, tronco-meio, tronco-base

2. ano: folha, tronco-ponta, tronco-meio, tronco-base

3? ano: folha, galho, tronco-ponia, tronco-meio, tronco-base

4․ ano: folha, galho-seco ${ }^{(*)}$, galho primário-ponta, galho primärio base, tronco-ponta, tronco-meio, tronco-base.

Coletaram-se, tambëm, amostras do terceiro e quarto anos, correspondente à leguminosa e cobertura morta existente sobre o solo.

Foram retiradas amostras representativas de caud mate rial, sendo enviadas para determinação da matēria seca e anālise quîmica.

As amostras foram lavadas e pesadas em laboratörio, de acordo com as recomendações de SARRUGE e HAAG (1974), e colocadas para se car em estufa a $70-75^{\circ} \mathrm{C}$.

Após peso constante ${ }^{(* *)}$, o material foi moído em moinho

(*) refere-se a galho desfolhado.

(**) utilizou-se peso, em vez de massa, apenas por ser mais comum. 
tipo Willey e analisado para N (Micro-Kjeldahl), P (Colorimetria), K (Fotometria de Chama), Ca, Mg e S (Absorção Atômica), B (Colorimetria),Cu, Fe, Mn e Zn (Absorção Atômica). Esses mëtodos estão descritos em SARRUGE e HAAG (1974). Os dados obtidos foram analisados estatisticamente através do Método "Experimentos Intei ramente Casualizados", como pode ser notado pela forma de coleta, para a concentração de cada nutriente na folha e pa ra a quantidade total de cada nutriente na planta inteira. 


\section{RESULTADOS E DISCUSSAO}

\subsection{Crescimento}

A anālise de crescimento, avaliada atravēs do acúmulo de matéria seca nas diversas partes da planta e na planta inteira, em fun ção das idades, encontra-se na Tabela 6. A anălise estatistica è apresentada na Tabela 7, estando baseada apenas no peso total da planta. Nota-se que o incremento de matéria seca do primeiro para o segundo ano não foi significativo, mostrando um crescimento lento inicialmente. Porém, a partir do terceiro ano, o crescimento foi estimulado, com o incremento de matëria seca quase triplicando em relação ao ano anterior, o mesmo acontecendo no quarto ano em relação ao terceiro.

Comparando-se esses resultados com os obtidos por SHORROCKS (1965a) e LIM (1977), nota-se que o crescimento da seringueira na Maläsia foi bem mais intenso. Enquanto no primeiro ano, no Acre, o peso da matéria seca total atinge $242 \mathrm{~kg} / \mathrm{ha}$, com um incremento para o segundo ano de 1,4 vezes, na Malásia chega a $1200 \mathrm{~kg} / \mathrm{ha}$, com um incremento de 6,7 
vezes. Uma possível explicação para essa grande diferença de crescimento é a utilização de clones diferentes.

A equação de regressão que mais se ajustou a esse tipo de crescimento foi a quadrática, assinalada, juntamente com a curva correspondente, na Figura 1.

Analisando-se ainda a Tabela 6 , observa-se que a matéria se ca das folhas foi praticamente a mesma nos dois primeiros anos, aumentan do 2,5 vezes do segundo para o terceiro ano e 2,2 vezes do terceiro para o quarto ano. Isso pode ser explicado pelo fato da seringueira não trocar de folhas no primeiroe segundo anos e, sim, a partir de 3-4 anos de idade. Já os galhos apresentaram um aumento de 8,0 vezes do terceiro parao quarto ano, mostrando um desenvolvimento intenso desse örgão nesse período, sen do que a base dos galhos primärios apresentaramomaior acúmulo de matéria seca no quarto ano. Quanto ao tronco, todas as suas partes mostraram pouco desenvolvimento do primeiro parao segundo ano, com a ponta apresentando o maior aumento do segundo para terceiro ano $(4,2$ vezes) e a base do terceiro para o quarto ano $(2,6$ vezes $)$.

A porcentagem de matēria seca referente a cada órgão da planta é apresentada pela figura 2. A variação da matēria seca do primeiro ao quarto ano foi de: 28,0 a $17,9 \%$ nas folhas; 9,3 (terceiro ano) a $26,7 \%$ nos ga Ihos e 72,0 a 55,5\% no tronco. Nota-se que como passar do tempo, houve um aumento na porcentagem de matēria seca dos galhos, ocorrendo uma diminuição para folhas e tronco. Observa-se tambēm que, proporcionalmente, a porcentagem de.matēria seca das folhas em relação ao total è bem al ta, um fato mui to importante no caso da ciclagem de nutrientes, pois como a seringueira troca de folhas num determinado período do ano, haverá uma devolução de nutrientes ao solo. 


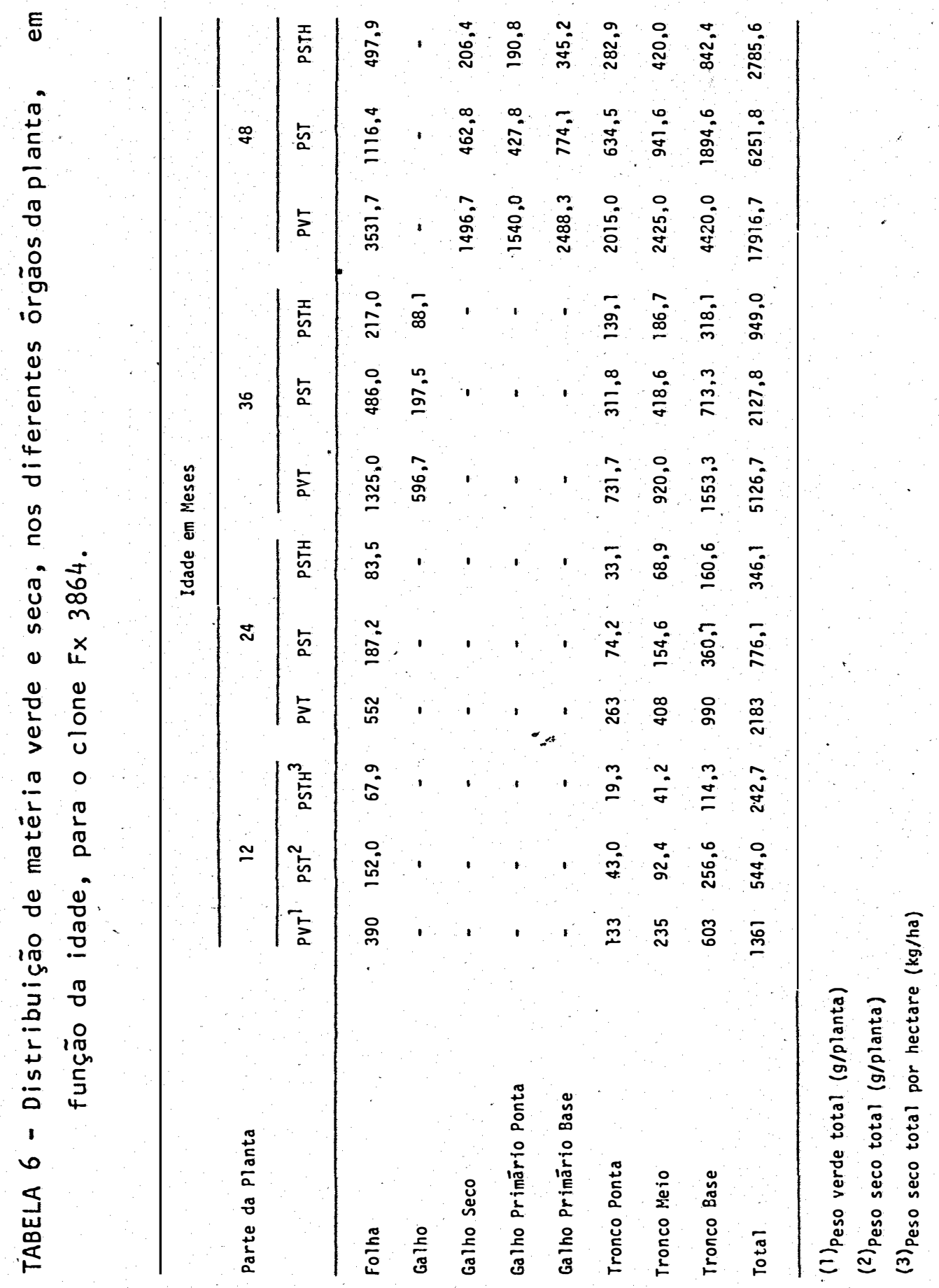




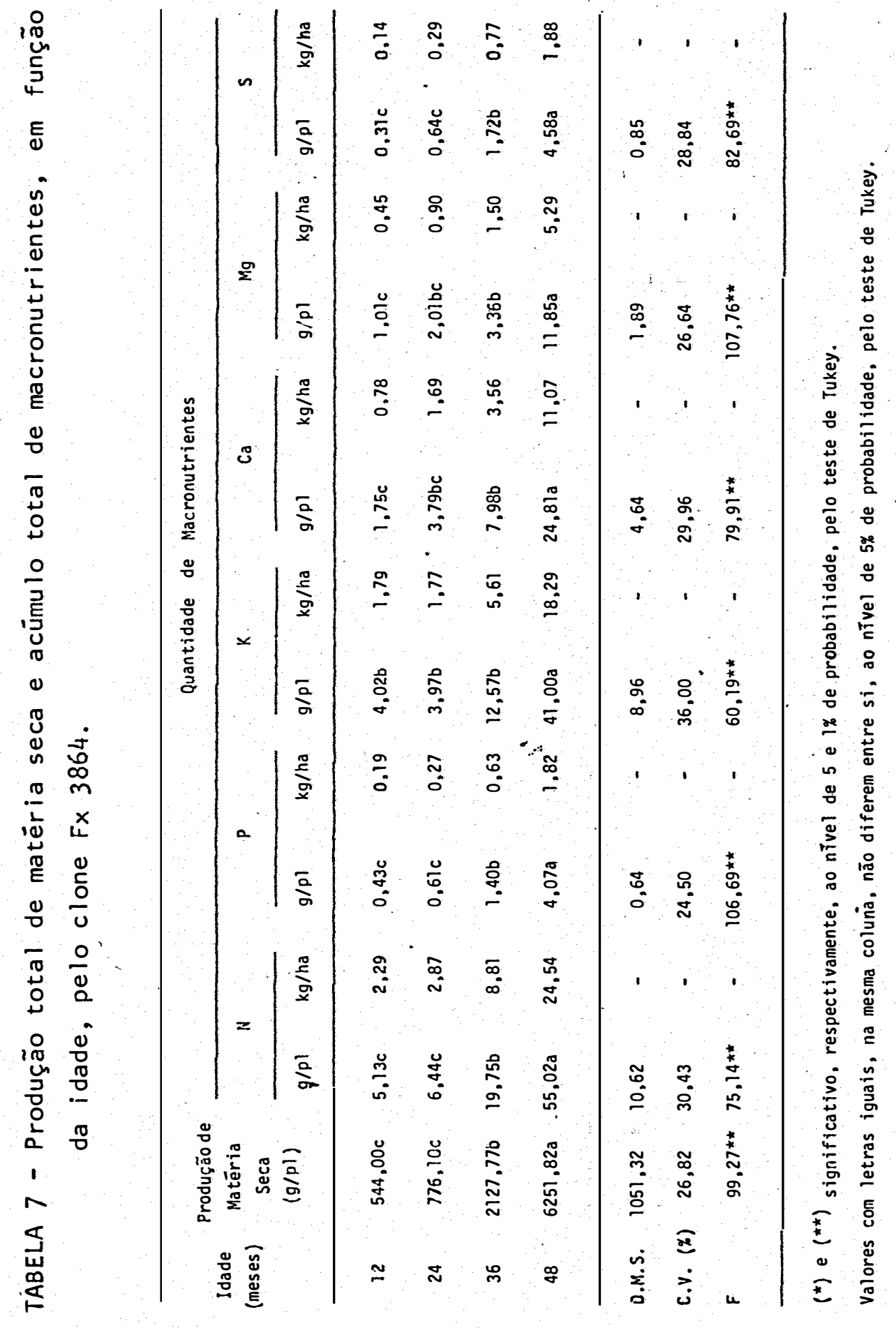




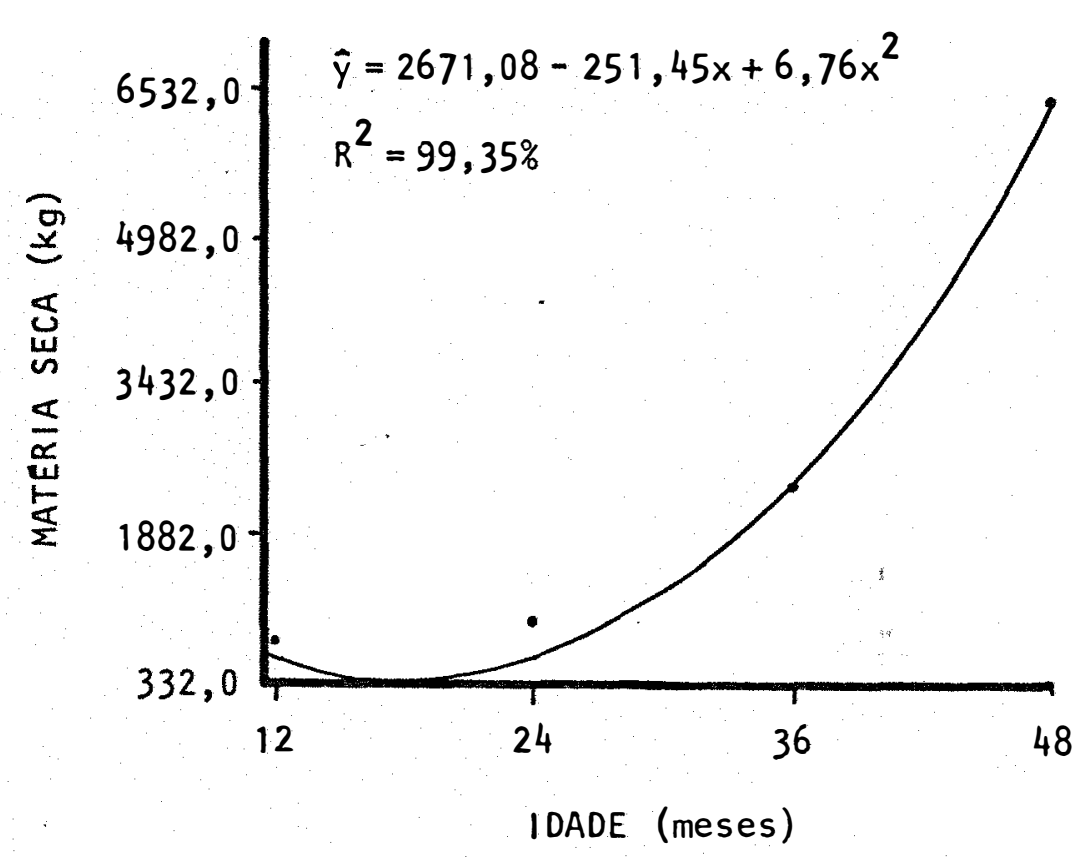

FIGURA 1 - Produção total de matēria seca, em função da idade ( $\hat{y}=$ peso de matéría seca; $x=i d a d e)$.

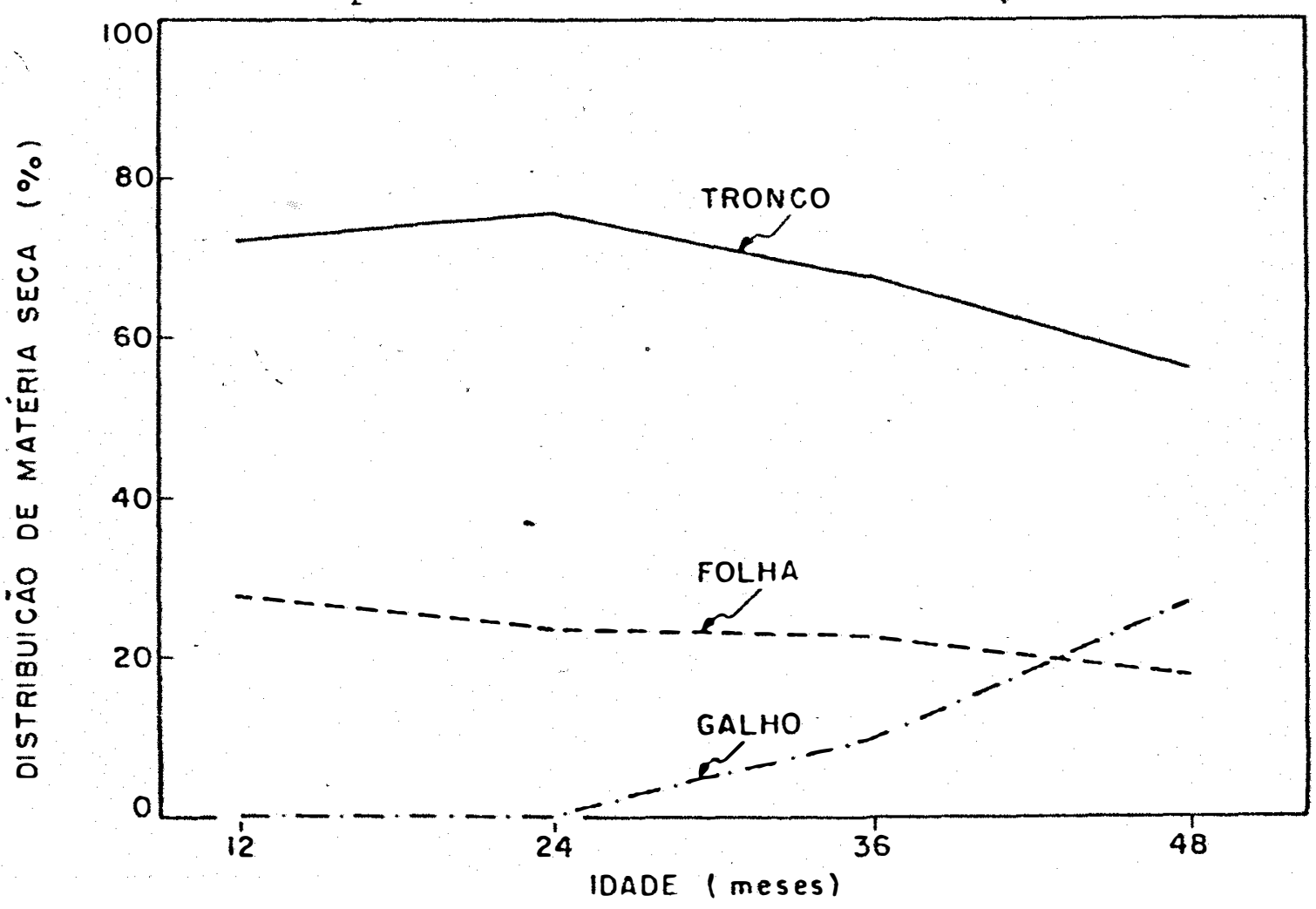

FIGURA 2 - Distribuição da matēria seca entre folhas, tronco e galhos, em função da idade. 


\subsection{Extração de Macronutrientes}

\subsubsection{Nitrogênio \\ 4.2.1.1. Concentração}

A concentração de nitrogênio nas folhas, com base no peso da matéria seca, em função da idade, é apresentada na Tabela 8 . Nota-se que não houve variação na concentração durantẹ os três primeiros anos, ocorrendo um aumento significativo apenas no quarto ano. Ajustou-se regressão quadrática para esse tipo de variação, sendo apresentada, juntamente com a curva correspondente, na Figura 3. Essa curva apresenta um ponto de mínimo de $2,15 \%$ aos 22 meses de idade. Esses dados não concor dam com os obtidos por SHORROCKS (1965a), pois houve uma variação entre a concentração de nitrogềnio na folha e a idade da plạnta. No quarto ano, a concentração desse elemento na folha $(2,77 \%)$ foi praticamente igual à média apresentada pelo autor anterior $(2,79 \%)$, embora esteja bem abaixo dos níveis médios obtidos em casa de vegetação por PUSHPARAJAH (1977), ou seja, 4,22\% para o clone GL 1, 3,83\% para o clone RRIM 701 , 3,67\% para o c्lone RRIM 501 e 3,59\% para o clone PB 86 . Essa grande diferença de concentração pode ser devido às diferenças clonais, assim como aos diversos fatores citados por PUSHPARAJAH (1977) e PUSHPARAJAH e TAN (1972).

A Tabela 9, que apresenta a concentração de nitrogênio nas diversas partes do tronco em função da idade, mostra que a concentração desse elemento na ponta e no meio do tronco diminuiu com a idade, ocorrendo o contrário para sua base. Nos três primeiros anos, a ponta do tron co apresentou as maiores concentrações, sendo ultrapassada pela base no 
quarto ano. Nesse ültimo ano, a concentração obtida para a base do tron co $(0,43 \%)$ è quase a mesma que a obtida por SHORROCKS (1965a) em ärvores adultas $(0,45 \%)$.

A concentração de nitrogênio nas diversas partes dos gaIhos em função da idade, observada na Tabela 10, indica que a concentração desse elemento diminuiu do terceiro para o quarto ano, sendo que nesse ültimo ano, os galhos secos apresentaram concentrações superiores a ponta dos galhos primärios, e que por sua vez, apresentaram maiores concentraçōes em relação à sua base. Essa maior concentração de ni trogênio na ponta em relação à base dos galhos primários é devido a essa região a presentar um crescimento mais intenso e, portanto, necessitar demaior con centração de nutrientes. As concentrações obtidas no quarto ano $(0,74 \%$ para galhos secos e uma média de $0,50 \%$ para os galhos primários) foram bem diferentes das obtidas por SHORROCKS (1965a) emärvores adultas $(0,93 \%$ para galhos verdes e $0,45 \%$ para os galhos restantes), podendo ser resultado da utilização de clones diferentes.

\subsubsection{Acümulo}

A variação na quantidade total de nitrogênio na planta em função da idade é apresentada na Tabela 7. Obšerva-se que a absorção de nitrogênio pelas plantas foi baixa inicialmente, quase não variando do primeiro para o segundo ano, correspondendo a um pequeno desenvolvimento da planta nesse período, mas tendo um aumento significativo no terceiro e, principalmente, no quarto ano. Esse resultado è conträrio àque le apresentado por SHORROCKS (1965a), que obteve um grande aumento 
na absorção de nitrogênio do primeiro para o segundo ano, diminuindo em relação ao terceiro. Também observa-se que as quantida des de nitrogênio extraídas pela seringueira, obtidas pelo referido autor, são bem maiores quando comparadas com as obtidas neste trabalho. Enquanto na Màäsia a planta retirou $11,8 \mathrm{~kg} / \mathrm{ha}$ no pri meiro ano, chegando a atingir $351,1 \mathrm{~kg} / \mathrm{ha}$ no quarto ano, nas con dições do Acre, a planta retirou apenas $2,3 \mathrm{~kg} / \mathrm{ha}$ no primeiro ano, atingindo $24,5 \mathrm{~kg} / \mathrm{ha}$ no quarto ano. Uma das possiveis causas dessa grande diferença no acümulo de nitrogênio è a utilização de clones diferentes.

A equação de regressão que melhor se ajustou à variação da quantidade total de nitrogênio em relação à idade foi a quadrātica, assinalada, juntamente com a curva correspondente, na Figura 4.

A Tabela 8 apresenta as variações da quantidade de $\mathrm{n}$ trogênio nas folhas em função da idade da planta. Nota-se que a quantidade dešse elemento quase não variou do primeiro para o segundo ano, aumentando 2,7 vezes do segundo para o terceiro ano e 2,8 vezes do terceiro para o quarto ano. No ültimo ano, as folhas a presentaram uma quantidade estimada de nitrogênio de quase $14 \mathrm{~kg} / \mathrm{ha}$, o que mostra o grande acúmulo desse elemento nesse órgão.

Quanto à variação da quantidade de nitrogênio no tronco, apresentada na Tabela 9, observa-se que houve um aumento na quantidade de nitrogênio de 1,4 vezes do primeiro para o segundo ano, triplicando 
do segundo para o terceiro ano e apresentando um aumento de 2,1 vezes do terceiro para o quarto ano. Durante os quatro anos, a distribuição da quantidade desse elemento nas diversas partes do tronco foi sempre a seguinte: base > meio > ponta. No ültimo ano, o tronco apresentou uma quan tidade total estimada de nitrogênio de $6,3 \mathrm{~kg} / \mathrm{ha}$, ou seja, menos da meta de da quantidade acumulada pelas folhas.

Atravēs da Tabela 10, que apresenta a variação da quantidade de nitrogênio nos galhos, observa-se que houve um aumento do tercei ro para o quarto ano de 2,5 vezes. Nesse ültimo ano, os galhos secos e a base dos galhos primários mostraram praticamente a mesma quantidade de nitrogênio, superando a existente na ponta dos galhos primärios. 0 maior acúmulo na base é devido a esta possuir maior peso de matéria seca do que a ponta. A quantidade total estimada desse elemento nesse ano, apresentada pelos galhos, foi de $4,4 \mathrm{~kg} / \mathrm{ha}$.

Considerando a quantidade total de nitrogênio na planta como sendo igual a 100\%, a distribuição porcentual desse elemento em cada órgão è apresentada na Figura 5. As folhas apresentaram as maiores quantidades desse elemento, decrescendo de $66,8 \%$ no primei ro ano até $56,4 \%$ no quarto ano, mostrando, pòrtanto, que mais da metade do nitrogênio absorvido pela planta estā concentrado nas folhas. Como a seringueira é uma planta caducifólia, a queda das folhas devolverā essa grande quantidade de nitrogênio ao solo, sendo esse um processo muito importante para o aumento da fertilidade do solo, além da grande importância para o ciclo de nutrientes. Esses dädos não concordam com os obtidos por LIM (1977), para o qual o nitrogênio se acumula em maiores proporções nos 
galhos. A distribuição desse elemento no tronco varia de $33,2 \%$ no primeiro ano até $25,7 \%$ no quarto ano. Observa-se que hä um pequeno aumento no segundo ano, caindo no terceiro e quarto anos. Essa queda è devido ao aumento na distribuição do elemento nos galhos, não podendo-se prever se nos anos seguintes irä ultrapassar as quantidades apresentadas pelo tron co e folhas. 


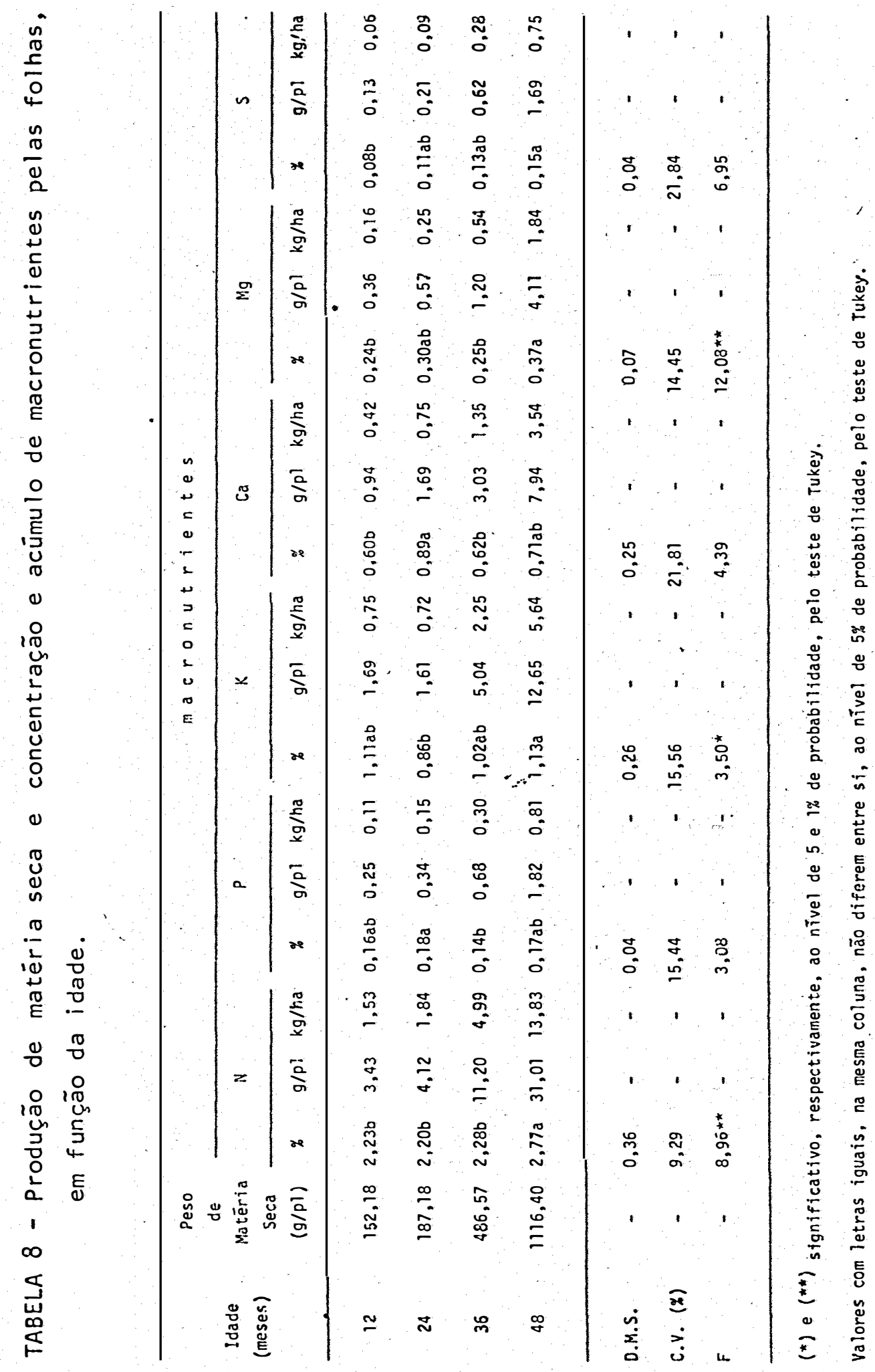




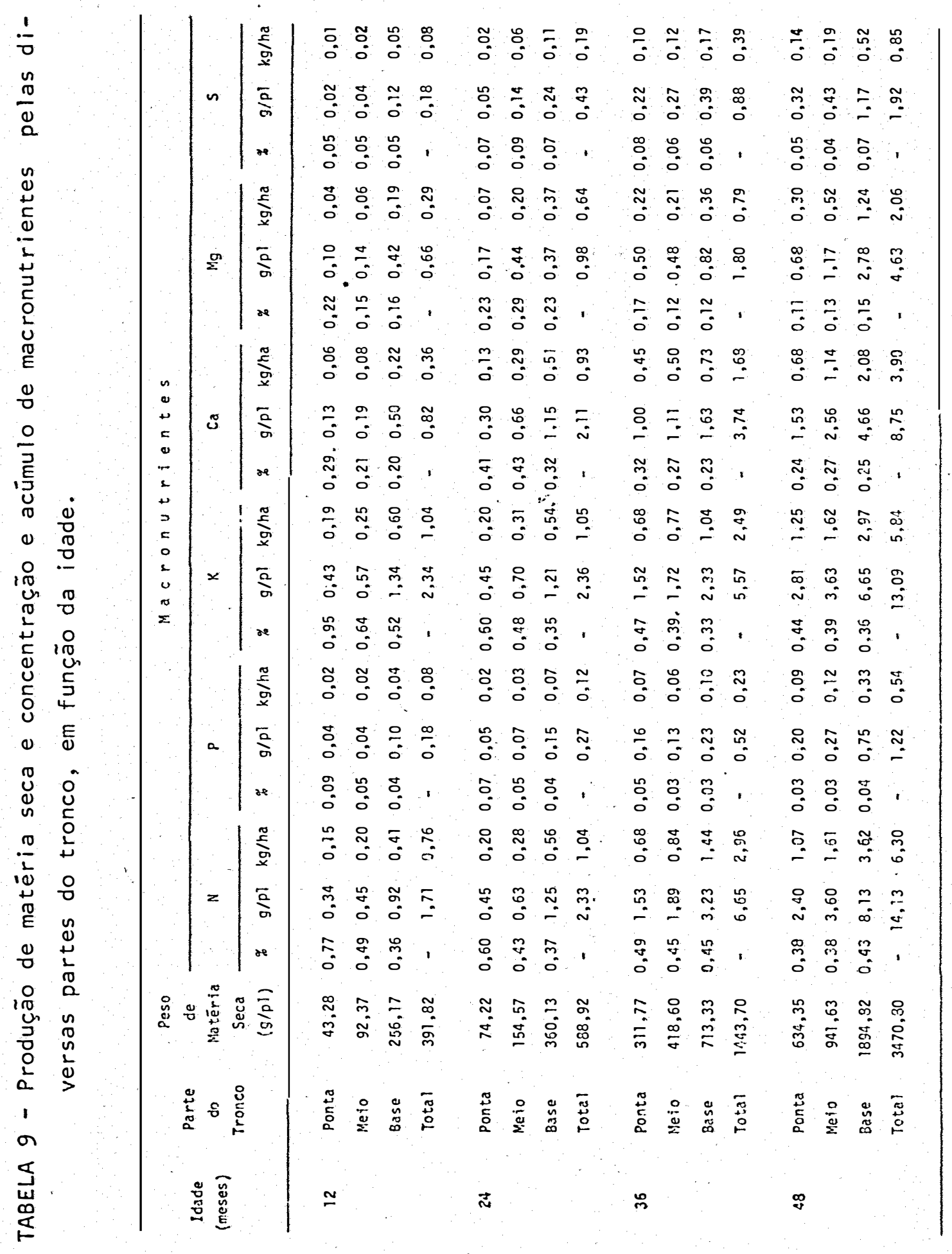




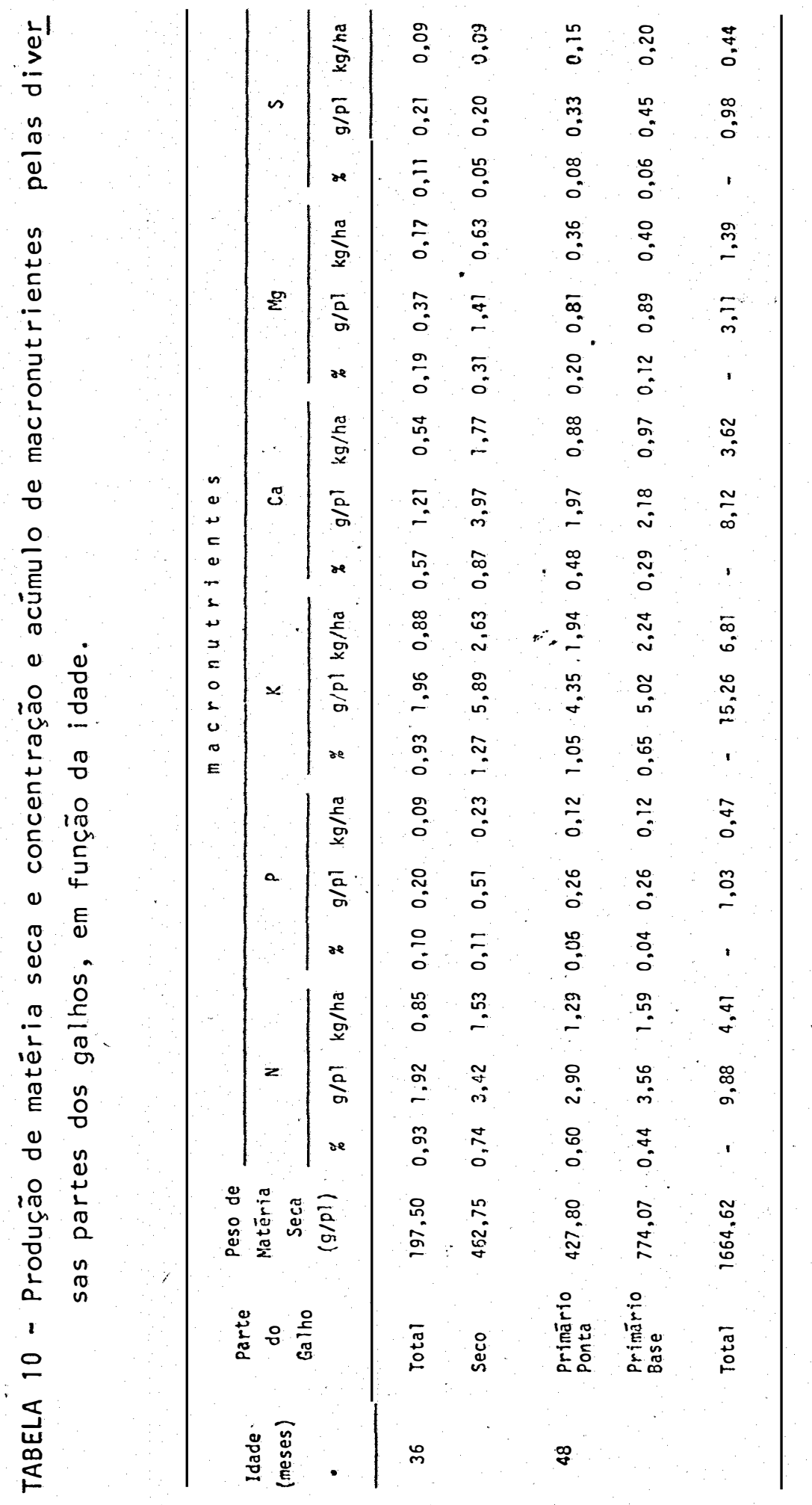




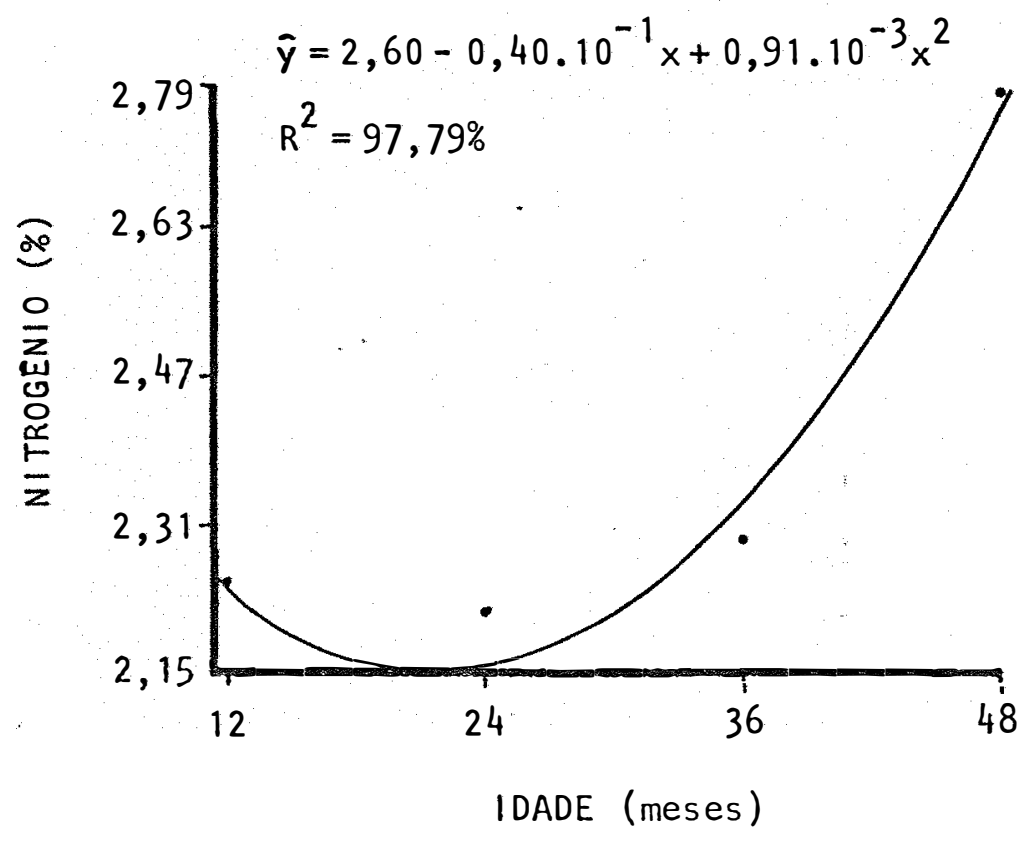

FIGURA 3 - Concentração de nitrogênio nas folhas, em função da idade ( $\hat{y}=$ concentração de nitrogênio; $x=$ idade).

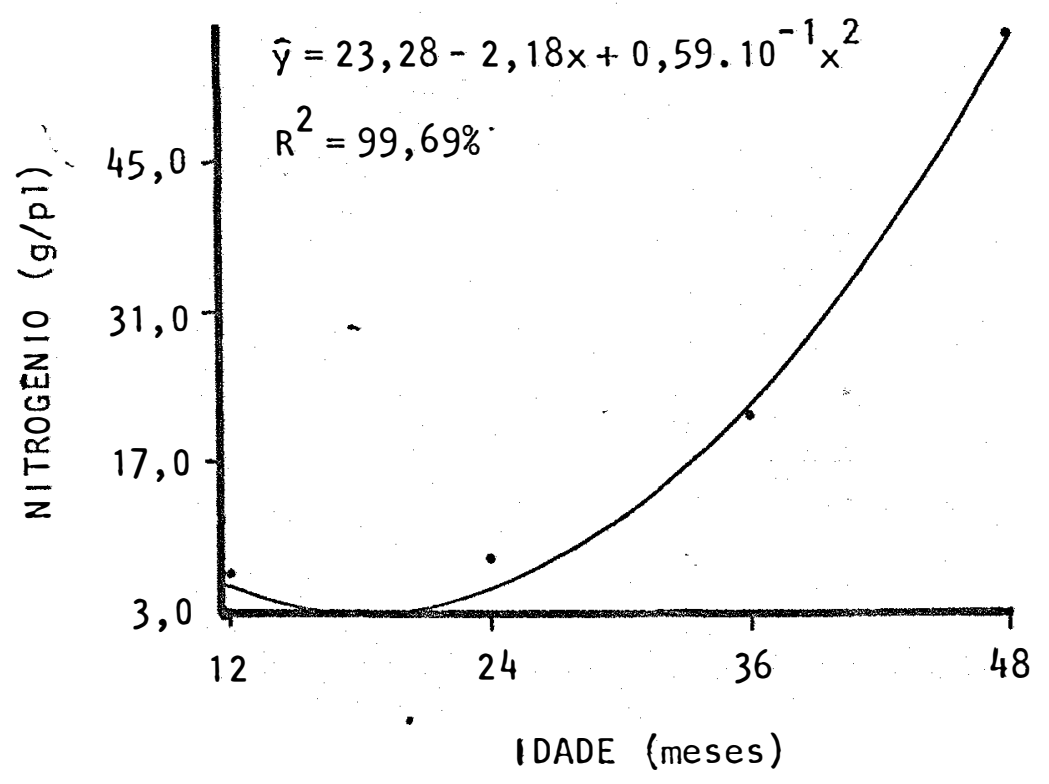

FIGURA 4 - Acúmulo total de nitrogênio na planta, em função da idade ( $\hat{y}=$ acúmulo de nitrogênio; $x=$ idade). 


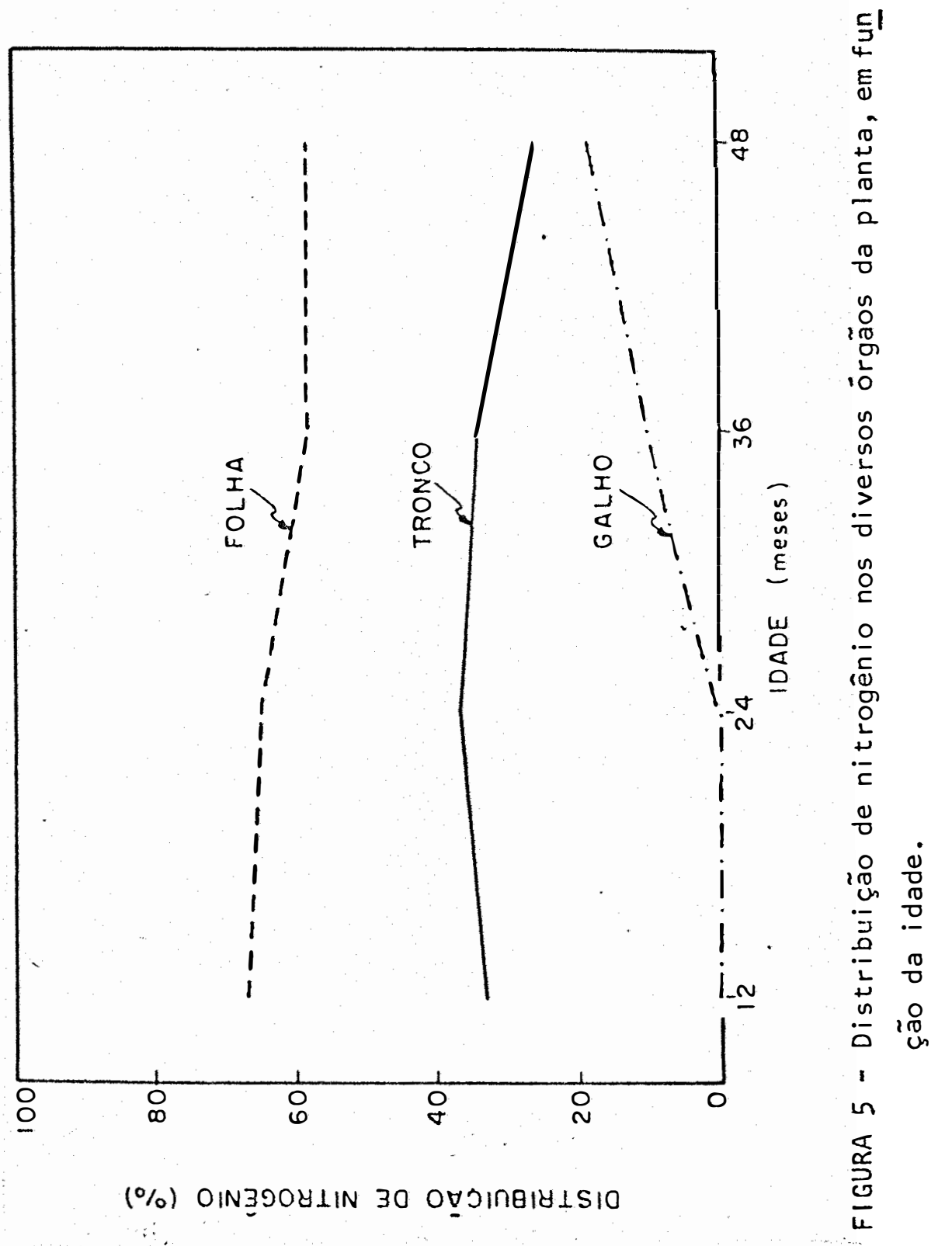




\subsubsection{Fösforo}

\subsubsection{Concentração}

Os dados analíticos referentes à concentração de fösforo nas folhas com base no peso de matéria seca, em função da idade, são apresentados na Tabela 8. Não se ajustou nenhuma regressão para es se tipo de variação, pois não houve diferenças significativas nas concentrações de fōsforo do primeiro, segundo e quarto anos, ocorrendo um decréscimo significativo no terceiro ano em relação ao segundo.

A concintração desse elemento na folha $(0,17 \%)$, obtida no quarto ano, foi praticamente igual à média apresentada por SHORROCKS (1965a), em àrvores adultas, que obteve $0,18 \%$, estando abaixo das concentrações médias obtidas por PUSHPARAJAH (1977), também em ärvores adultas $(0,211 \%$ para os clones AVROS, $0,194 \%$ para os clones PR e $0,226 \%$ para os clones RRIM).

Atravēs da Tabela 9, que apresenta a concentração de fósforo nas diversas partes do tronco em função da idade, observa-se que essa concentração diminuiu com o aumento da idade devido ao seu decréscimo no meio e na ponta do tronco,enquanto que a base apresentou a mesma concentração durante os quatro anos. A concentração obtida no quarto ano, $0,04 \%$ para a base do tronco,quase iguala-se à média apresentada por SHORROCKS (1965a) em ärvores adultas $(0,05 \%)$.

Com relação à concentração de fösforo nas diversas par tes dos galhos em função da idade, observada na Tabela 10, nota-se que 
a concentração desse elemento no terceiro ano foi equivalente a dos ga Ihos secos no quarto ano, a qual superou a concentração da ponta e base dos galhos primários. Quanto a estes, a ponta apresentou concentra ções superiores à sua base por ser uma região de crescimento mais intenso e, portanto, necessitar de uma maior concentração de nutrientes. Nesse ültimo ano, as concentrações obtidas para galhos secos $(0,11 \%)$ e galhos primários (cerca de $0,05 \%$ ) foram bem diferentes em relação às obtidas por SHORROCKS (1965a) em ärvores adultas, ou seja, $0,11 \%$ para galhos verdes e $0,05 \%$ para os galhos restantes,podendo ter sido causada pela utilização de clones diferentes nos dois experimentos.

\subsubsection{Acümulo}

A Tabela 7 apresenta a quantidade total de fósforo acu mulada na planta em função da idade. Nota-se que nos dois primeiros anos, a absorção de fósforo quase não variou, coincidindo com o pequeno desenvolvimento da planta nesse período, enquanto que no terceiro ano houve um aumento significativo em relação ao segundo, o mesmo ocorrendo para o quarto ano, onde a quantidade absorvida quase triplicou quan do comparada com a do ano anterior. Esses resultados não concordam com os obtidos por SHORROCKS (1965a), que obteve um grande incremento na absorção de fösforo no segundo ano,diminuindo no terceiro. Além disso, fazendo-se uma comparação entre as quantidades extraídas pela se ringueira, observa-se que enquanto SHORROCKS (1965a) obteve $1,4 \mathrm{~kg} / \mathrm{ha}$ no primeiro ano e $30,0 \mathrm{~kg} / \mathrm{ha}$ no quarto ano, nas condições do Acre foi obtido $0,2 \mathrm{~kg} / \mathrm{ha}$ no primeiro ano e $1,8 \mathrm{~kg} / \mathrm{ha}$ no quarto ano. Essa dife 
rença pode ter sido causada, possivelmente, pela utilização de clones diferentes.

A curva correspondente à variação de quantidade de fösforo em relação à idade è apresentada na Figura 6, juntamente com a equação de regressão quadrātica, que foi aquela que mais se ajustou a esse tipo de variação.

A variação da quantidade de fösforo nas folhas em função da idade da planta é apresentada na Tabela 8. Observa-se que o acúmulo de fósforo pelas folhas aumentou muito pouco do primeiro para o segundo ano, duplicando do segundo para o terceiro ano e aumentando cerca de 2,7 vezes no ültimo ano, quando apresentou o acūmulo de $0,81 \mathrm{~kg} / \mathrm{ha}$ de fösforo, quantidade pequena mas importante, pois deverä ser devolvida ao solo.

Quanto à variação na quantidade de fösforo no tronco, apresentada na Tabela 9, nota-se que ocorreram aumentos crescentes na absorção desse elemento com o passar do tempo, com cerca de 1,5 vezes do primeiro para o segundo ano, 1,9 vezes do segundo para o terceiro ano e 2,3 vezes do terceiro para o quarto ano. Durante os quatro anos a base do tronco apresentou quantidades superiores ao meio e à ponta, sendo que no ültimo ano a quantidade total de fósforo acumulada pelo tronco foi de $0,54 \mathrm{~kg} / \mathrm{ha}$, quantidade bem inferior àquela acumulada pelas folhas.

A Tabela 10, que apresenta a variação na quantidade de fösforo nos galhos, mostra que houve um aumento no acūmulo desse ele- 
mento de 5,2 vezes do terceiro para o quarto ano, sendo que no ültimo ano os galhos secos apresentaram quantidades superiores à base e à ponta dos galhos primärios. Nesse ano, a quantidade total de fósforo acumulada pelos galhos foi de $0,47 \mathrm{~kg} / \mathrm{ha}$.

A distribuição porcentual de fósforo em cada örgão da planta, considerando a quantidade total desse elemento na planta como sendo igual a $100 \%$, é apresentada na Figura 7 . 0 fósforo acumulouse em maiores quantidades nas folhas, atingindo um valor māximo no primeiro ano $(44,7 \%)$, e diminuindo com o aumento da idade. Esses dados contradizem os obtidos por LIM (1977), para o qual há maior acúmulo de fósforo nos galhos. No tronco, a porcentagem desse elemento variou de $42,2 \%$ no primeiro ano at ${ }^{-}$e $29,9 \%$ no quarto, notando-se um pequeno aumen to no segundo ano e uma elevada queda no terceiro e quarto anos. Ao mesmo tempo em que ocorreu essa queda no tronco e nas folhas, houve um grande aumento na quantidade de fósforo dos galhos, quase atingindo no quarto ano, a quantidade apresentada pelo tronco. Neste caso permanece a dúvida do que ocorreră nos anos seguintes. 


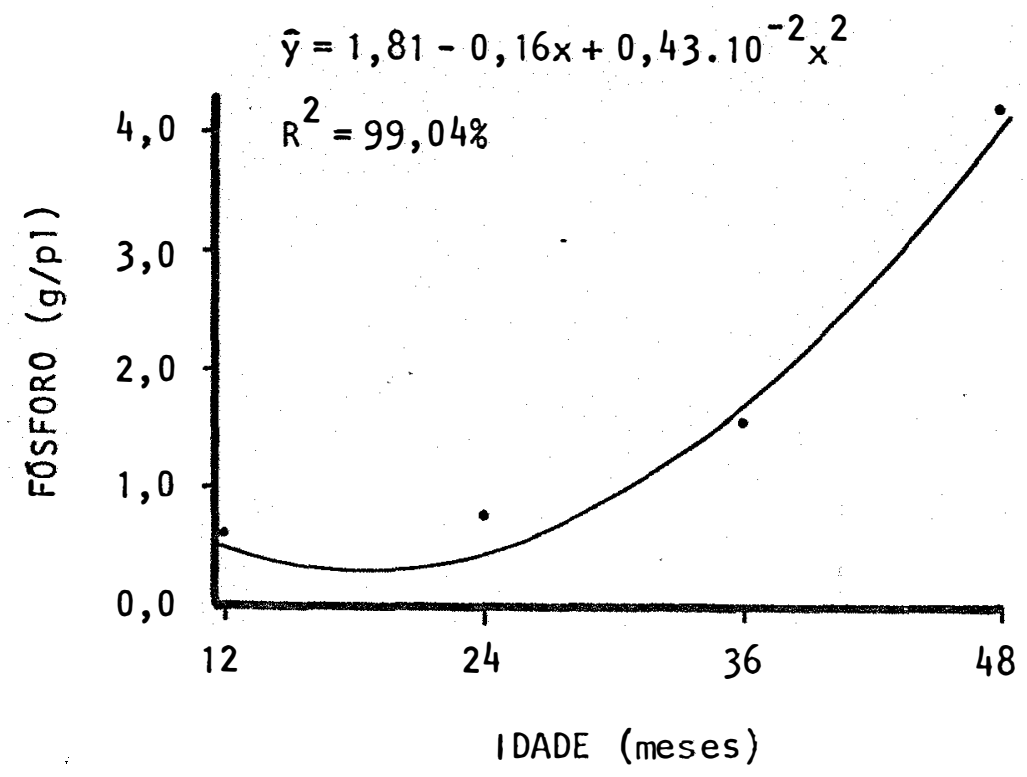

FIGURA 6 - Acúmulo total de fósforo na planta, em função da idade.

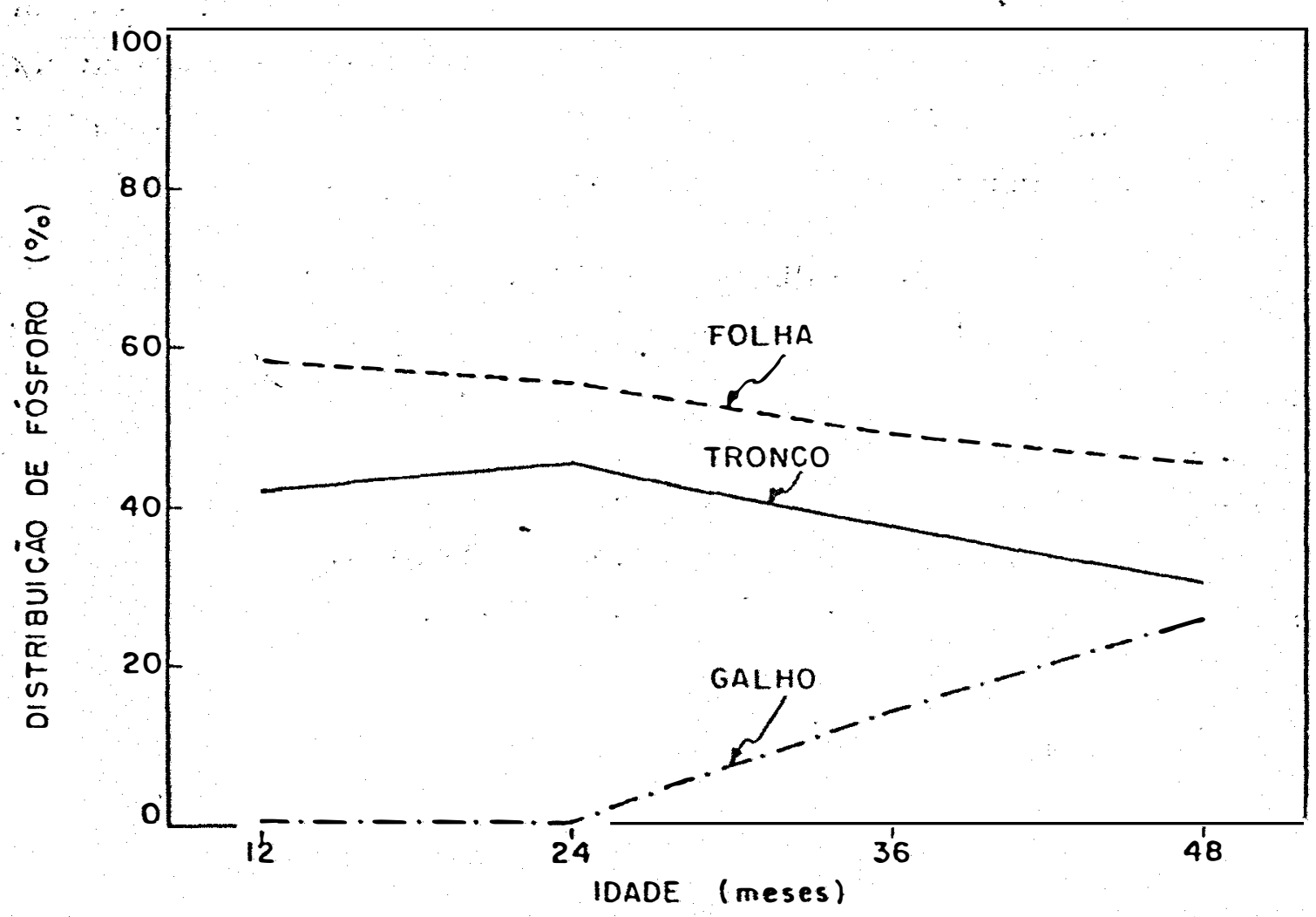

FIGURA 7 - Distribuição de fósforo nos diversos órgãos da planta, em função da idade. 


\subsubsection{Potāssio}

\subsubsection{Concentração}

Os valores da concentração de potássio nas folhas, com base no peso da matēria seca, em função da idade,estão apresentados na Tabela 8. Não houve diferenças na concentração de potāsssio durante os três primeiros anos, ocorrendo um aumento significativo no quarto ano em relação ao segundo. Ajustou-se regressão quadrática para esse tipo de variação,estando apresentada, juntamente com a curva correspondente, na Figura 8 .

No ültimo ano, a concentração de potássio na folha (1,13\%) foi superior à média apresentada por SHORROCKS (1965a) em ärvores adultas $(0,90 \%)$ e muito parecida com as médias obtidas por PUSHPARAJAH (1977), tambēm em árvores adultas $(1,14 \%$ para os clones AVROS, 1,12\% para os clones PR e $1,15 \%$ para os clones RRIM).

Atravēs da Tabela 9, observa-se que a concentração de potássio nas diversas partes do tronco diminuiu com o aumento da idade, sendo que a ponta do tronco sempre apresentou concentrações superiores ao meio e à base. No último ano, a ponta do tronco apresentou uma con centração de $0,44 \%$, superior à apresentada por SHORROCKS (1965a) em ärvores adultas $(0,35 \%)$.

A concentração de potássio nas diversas partes dos gaIhos, como pode ser observado pela Tabela 10, variou do terceiro para o quarto ano, aumentando para os galhos secos e ponta dos galhos primá 
rios e diminuindo para a base dos galhos primários. No quarto ano, os galhos secos apresentaram concentrações superiores às das ponta dos galhos primários, e que por sua vez, apresentaram maiores concentrações em relação à sua base, devido à maior intensidade de crescimento existente na ponta. Comparando-se os resultados obtidos no ültimo ano com os obtidos por SHORROCKS (1965a), em árvores adultas, nota-se que são bem diferentes, pois enquanto esse autor citta uma concentração mēdia de potássio de $0,63 \%$ nos galhos verdes e $0,27 \%$ nos galhos restantes na região da Malásia, nas condições do Acre obteve-se 1,27\% nos ga Ihos secos e 1,05 e 0,65\% na ponta e base dos galhos primários, respectivamente. Essa diferença pode ser resultado da "tilização de clo nes diferentes nos dois experimentos.

\subsubsection{Acümulo}

A quantidade total de potássio acumulada na planta em função da idade encontra-se na Tabela 7. A absorção desse elemento pelas plantas não variou significativamente nos três primeiros anos, ao conträrio de SHORROCKS (1965a) que obteve um aumento de 6 vezes do pri meiro para o segundo ano. Entretanto, a absorção no quarto ano apresentou um aumento significativo em relação aos anos anteriores. Obser va-se tambēm, comparando-se os dois trabalhos, que as quantidades citadas por SHORROCKS (1965a) são bem maiores que as obtidas neste traba1ho. Enquanto o autor obteve $7,0 \mathrm{~kg} / \mathrm{ha}$ no primeiro ano e $187,6 \mathrm{~kg} / \mathrm{ha}$ no quarto ano, nas condições do Acre a seringueira absorveu $1,8 \mathrm{~kg} / \mathrm{ha}$ no primeiro ano e $18,3 \mathrm{~kg} / \mathrm{ha}$ no quarto ano, sendo esta ültima quantida 
de cerca de 10 vezes menor que a verificada nos paises asiáticos. E provável que um dos fatores responsáveis por essa discrepância de resultados seja a utilização de-diferentes clones nos dois expe rimentos.

A equação de regressão que melhor se ajustou à va riação da quantidade total de potássio em relação à idade foi a quadrática, apresentada na Figura 9, juntamente com a curva cor respondente.

A quantidade de potássio acumulada pelas folhas, observada na Tabela 8, permaneceu a mesma do primeiro para o segundo ano, triplicando do segundo para o terceiro ano e apresentando um aumento de cerca de 2,5 vezes do terceiro para ò quarto ano. 0 potássio foi o segundo elemento mais acumulado pelas folhas, as quais apresentaram $5,64 \mathrm{~kg} / \mathrm{ha}$ no quarto ano, cuja quantidade deverä ser devolvida ao solo atravēs da queda das folhas, fechando o ciclo de nutrientes.

Quanto à variação da quantidade de potássio no tronco, mostrada pela Tabela 9, nota-se que não houve variação do primeiro para o segundo ano, aumentando 2,4 vezes de segundo para o terceiro ano, e- apresentando esse mesmo aumento do terceiro para o quarto ano. A distribuição da quantidade desse elemento pelo tronco mostrou que houve uma diminuição do teor no sentido base-ponta, provavelmente devido ao peso de matëria seca da base ser maior que a do meio e ponta. No ültimo ano, a quantidade total acumulada pelo tronco foi de $5,84 \mathrm{~kg} / \mathrm{ha}$, a 
qual iguala-se, praticamente, àquela acumulada pelas folhas, nesse mes mo período.

A Tabela 10 apresenta o acúmulo de potássio nos galhos em função da idade. Houve um aumento excepcional de 7,8 vezes do terceiro para o quarto ano, ocorrendo um acúmulo de $6,81 \mathrm{~kg} / \mathrm{ha}$ nesse ülti mo ano, quantidade superior à das folhas e do tronco. Os galhos secos apresentaram quantidades superiores a da base dos galhos primários, e estes em relação à sua ponta, devido à base possuir maior peso de maté ria seca do que a ponta.

Considerando a quantidade total de potássio na planta como sendo igual a $100 \%$, a distribuição porcentual desse elemento em cada örgão è apresentada na Figura 10. O tronco acumủlou as maiores quantidades de potássio, variando de $58,0 \%$ no primeiro ano atē $\quad 31,9 \%$ no quarto ano, sendo que neste ültimo ano o tronco é superado pelos ga lhos, que apresentam $37,2 \%$ de potássio. As follhas apresentaram sempre menores quantidades que o tronco, o que não ocorreu no caso do nitrogênio e do fósforo. A tendência da quantidade existente nos galhos superar a do tronco e das folhas, observada para os dois nutrientes anteriores, è confirmada no quarto ano para o potássio. Enquanto ocorreu um decréscimo no tronco e nas folhas, houve um aumento acentua do nos galhos, concordando com os resultados obtidos por LIM (1977). 


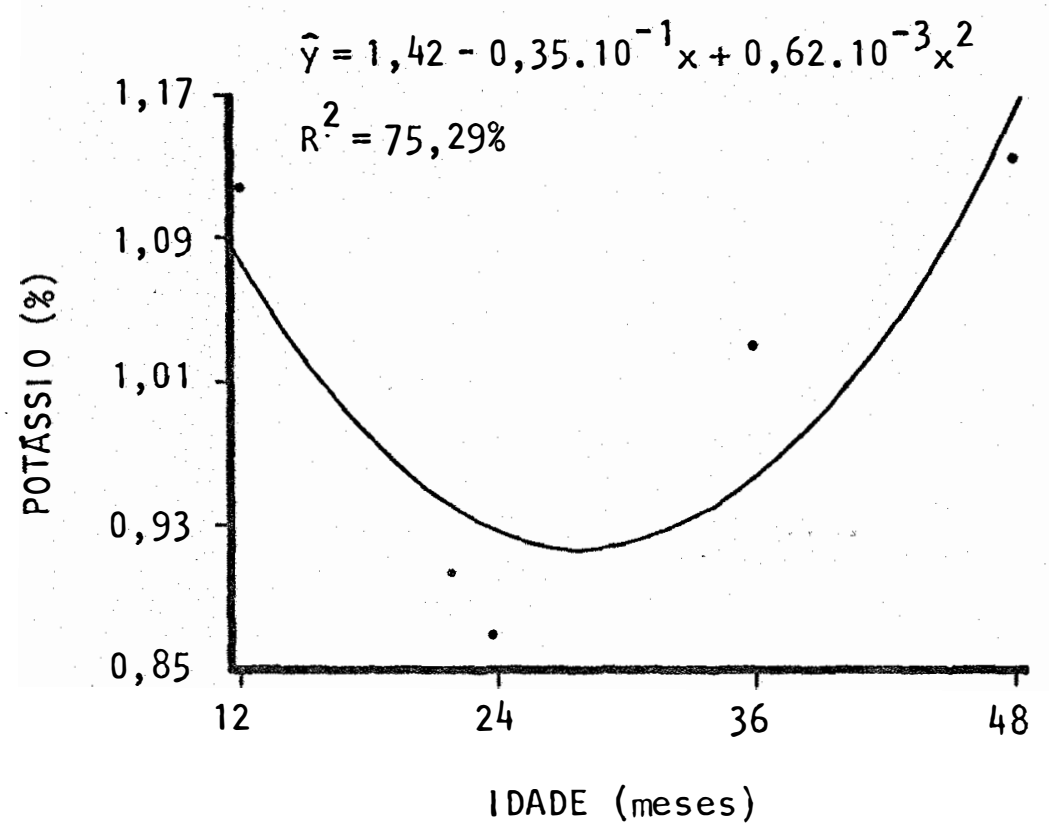

FIGURA 8 - Concentração de potássio nas folhas, em função da idade.

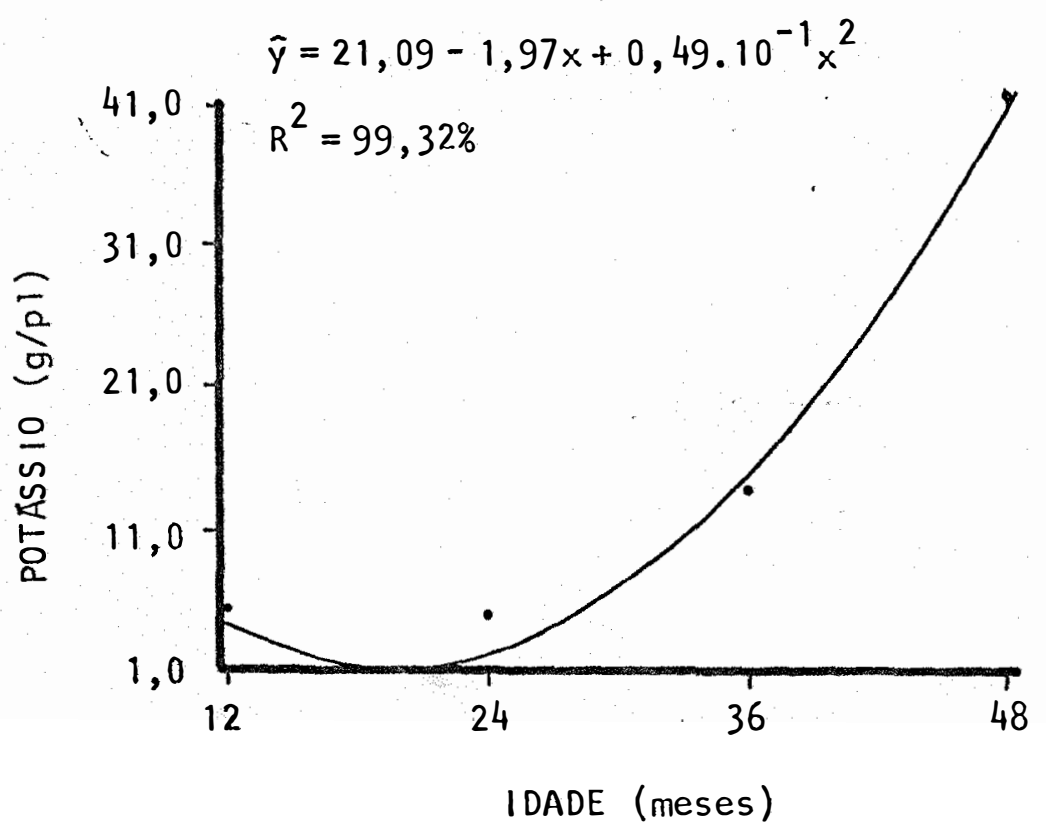

FIgURA 9 - Acūmulo total de potássio na planta, em função da idade. 


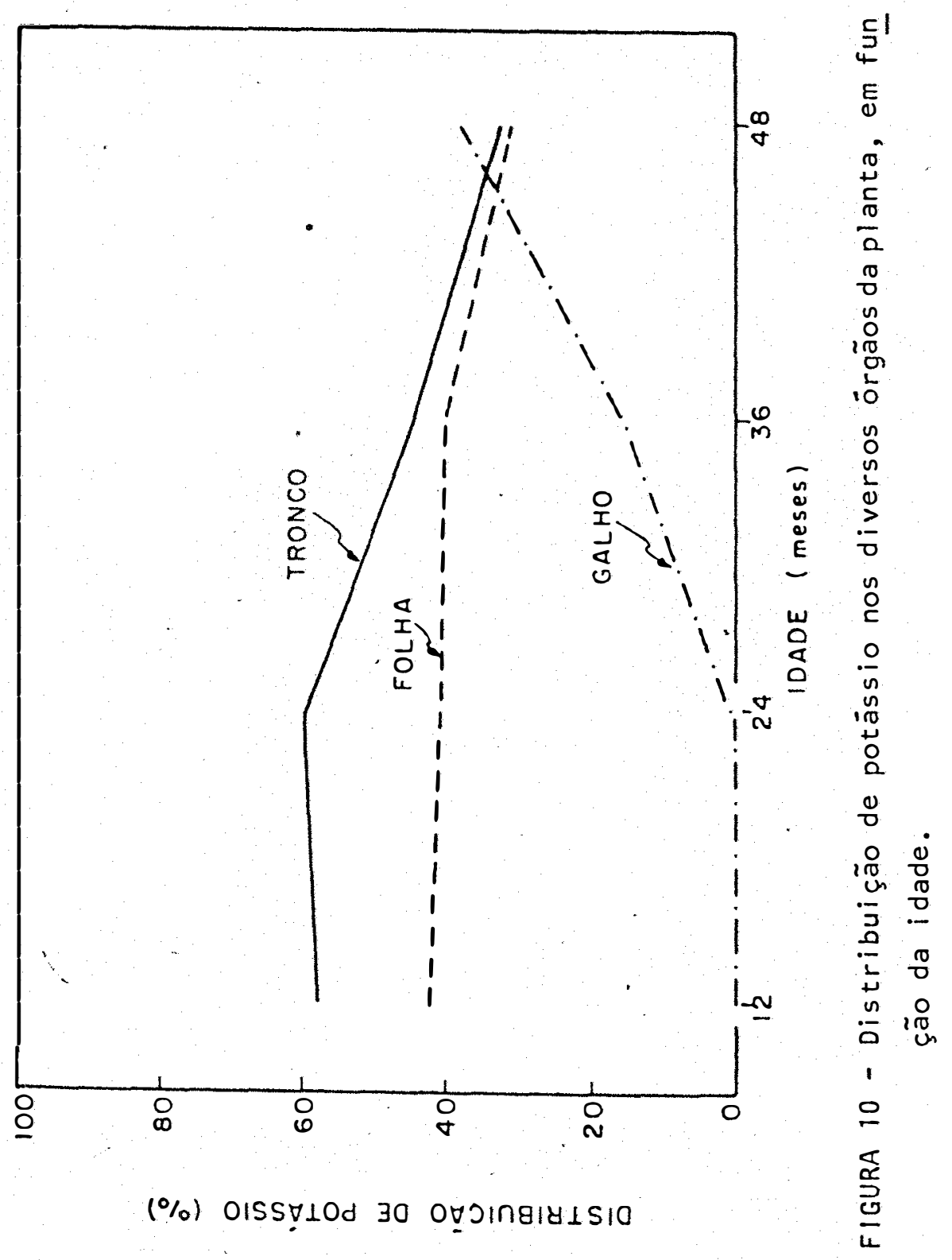




\subsubsection{Cálcio}

\subsubsection{Concentração}

A concentração de cálcio nas folhas, com base no peso de matéria seca, em função da idade, è apresentada na Tabela 8. Não se ajustou nenhuma equação de regressão para esse tipo de variação, pois apenas o segundo ano apresentou uma concentração significativamente sü perior à dos outros três, podendo ter sido causada pela alta quantidade de cálcio existente no solo onde estão assentados as ärvores desse ano.

0 quarto ano apresentou uma concentração de cálcio na folha de 0,71\%, inferior à média apresentada por SHORROCKS (1965a) em arvores adultas $(0,86 \%)$, mas muito próxima das médias obtidas por PUSHPARAJAH (1977), também em ärvores adultas ( $0,75 \%$ para os clones AVROS, $0,76 \%$ para os clones PR e $0,78 \%$ para os clones RRIM).

A concentração de cālcio nas diversas partes do tronco, mostrada pela Tabela 9, não apresentou uma tendência regular com o aumento da idade, sendo que o segundo ano apresentou a mais alta concentração, provavelmente devido ao alto teor de cálcio existente no solo que sustenta as árvores desse ano. A concentração obtida no quarto ano, $0,27 \%$ para o meio do tronco,foi inferior à média apresentada por SHORROCKS (1965a) em àrvores adultas, ou seja, 0,33\%.

A Tabela 10, que apresenta a concentração de cālcio nas diversas partes dos galhos em função da idade,mostra que ocorreu 
uma variação nessa concentração do terceiro para o quarto ano, aumentando para os galhos secos e diminuindo para a ponta e base dos galhos primärios. Os galhos secos apresentaram concentrações superiores à ponta e base dos galhos primärios, sendo que a da ponta foi superior à da base, provavelmente devido à maior intensidade de crescimento existente nessa parte dos galhos. As concentrações obtidas no quar to ano ( $0,87 \%$ para galhos secos e 0,48 e $0,29 \%$ para ponta e base dos galhos primärios, respectivamente) foram bem diferentes das obtidas por SHORROCKS (1965a) em árvores adultas $(0,82 \%$ para galhos verdes e $0,30 \%$ para os galhos restantes), podendo ser resultado da utilização de clones diferentes.

\subsubsection{Acúmulo}

A variação do acúmulo total de cálcio na planta em função da idade è apresentada na Tabela 7. A absorção desse elemento foi baixa inicialmente, quase não variando do primeiro para o segundo ano e com o terceiro ano apresentando um aumento signific ativo apenas em relação ao primeiro. No quarto ano, entretanto, a quantidade triplicou em relação ao ano anterior. Comparando-se esses resultados com os obtidos por SHORROCKS (1965a), nota-se que há uma grande diferença, pois esse autor obteve, nas condições da Malásia, um aumento de 7,0 vezes na absorção de cālcio do primeiro para o segundo ano, com incrementos menores nos anos subsequentes. As quantidades extraídas pela seringueira tambēm foram bem diferentes nos dois experimentos. Enquanto SHORROCKS (1965a) obteve um acúmulo de $4,5 \mathrm{~kg} /$ ha no primeiro ano e 
$168,7 \mathrm{~kg} / \mathrm{ha}$ no quarto ano, na região do Acre houve um acúmulo de $0,8 \mathrm{~kg} /$ ha no primeiro e $11,1 \mathrm{~kg} / \mathrm{ha}$ no quarto ano. Uma possível expli cação para essa grande diferença nos resultados é a utilização de clones diferentes.

A curva correspondente à variação da quantidade de cálcio em relação à idade é apresentada na Figura 11, juntamente com a equação de regressão quadrática, que foi aquela que mais se a justou a esse tipo de variação.

Através da Tabela 8, que apresenta a variação da quantidade de cálcio nas folhas, observa-se que houve um aumen to nessa quantidade de 1,8 vezes, tanto do primeiro para o segundo ano, como deste para o terceiro ano, e de cerca de 2,6 vezes do terceiro para o quarto ano. No ültimo ano, as folhas apresentaram uma quantidade estimada de cálcio de $3,54 \mathrm{~kg} / \mathrm{ha}$.

- Com relação à vảriação da quantidade de cálcio no tronco, apresentada na Tabela 9, observa-se que houve um aumento de 2,6 vezes do primeiro para o segundo ano, de 1,8 vezes do segundo para o terceiro ano e de 2,3 vezes do terceiro parao quarto ano. Durante os quatro anos, a distribuição da quantidade desse elemento nas partes do tronco foi sempre a seguinte: base $>$ meio > ponta, sendo que no quarto ano, o tronco apresentou um acúmulo estimado de $3,90 \mathrm{~kg} / \mathrm{ha}$, superior ao acumulado pe las folhas. 
A Tabela 10 apresenta as variações da quantidade de cál cio nos galhos em função da idade. Houve um grande aumento do terceiro para o quarto ano, com cerca de 6,7 vezes, ocorrendo um acúmulo de $3,62 \mathrm{~kg} / \mathrm{ha}$ nesse ūltimo ano, quantidade tambëm superior à acumulada pe. las folhas. Os galhos secos apresentaram quantidades superiores à da base dos galhos primārios, e estes em relação à sua ponta,devido à base possuir maior peso de matēria seca em relação à ponta.

A distribuição porcentual de cālcio em cada órgão da planta, considerando a quantidade total desse elemento na planta como sendo igual a 100\%, ē apresentada na Figura 12. As folhas apresentaram as maiores quantidades de cālcio no primeiro ano $(53,6 \%)$, sendo superadas pelo tronco nos anos seguintes. A porcentagem no tronco variou de $46,4 \%$ no primeiro ano, atingiu um mäximo de $55,6 \%$ no segundo e decresceu para $35,3 \%$ no quarto ano. Os galhos apresentaram um por centual de $32,7 \%$ no quarto ano, quase se igualando à quantidade existente no tronco. Se essa tendência for mantida, os galhos superarão o tronco nos anos seguintes, concordando com os resultados obtidos por LIM (1977), para o qual hā um maior acūmulo de cắlcio nos galhos. 


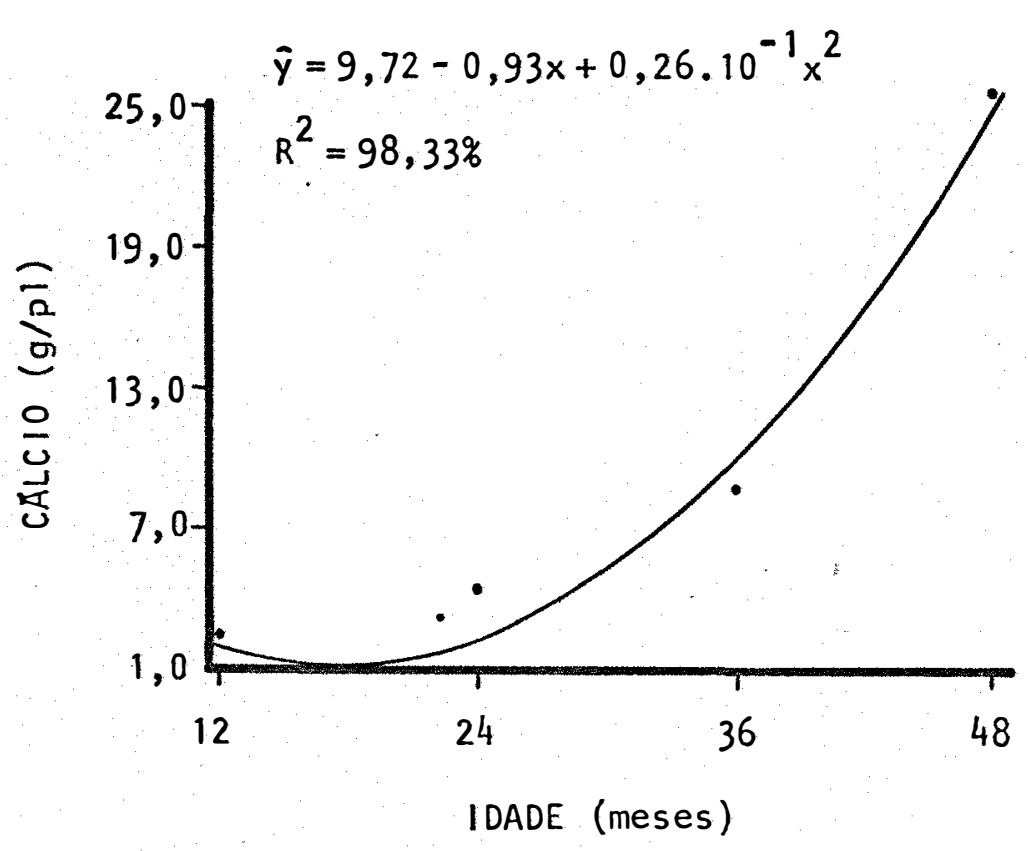

FIGURA 11 - Acümulo total de cālcio na planta, em função da idade.

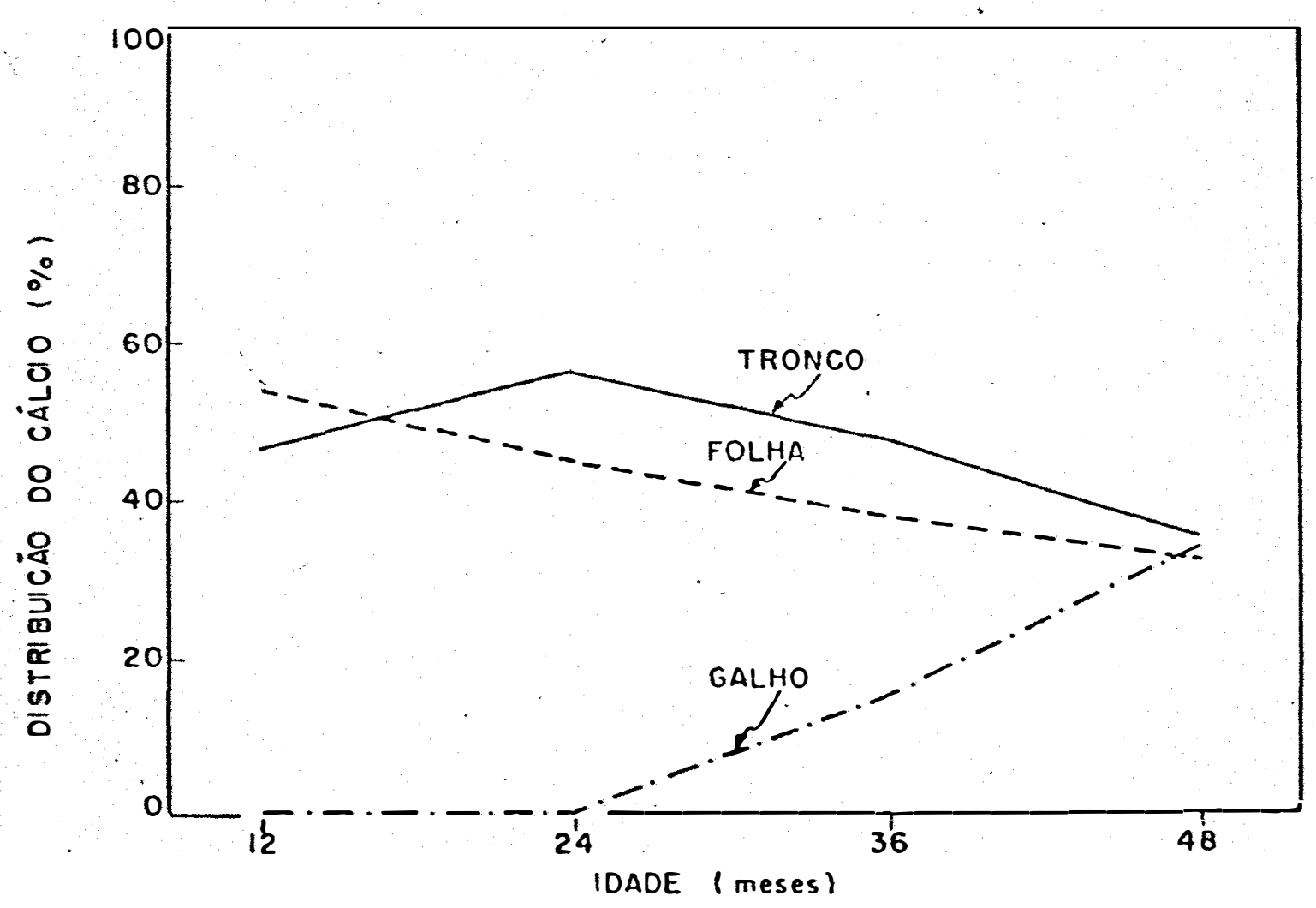

FIGURA 12 - Distribuição de cālcionos diversos órgãos da planta, em função da idade. 


\subsubsection{Magnësio}

\subsubsection{Concentração.}

Os dados analíticos referentes à concentração de magnésio nas folhas com base no peso de matéria seca, em função da idade, são apresentados na Tabela 8. Não se ajustou nenhuma equação de regres são para esse tipo de variação, pois não houve diferenças na concentração de magnésio durante os três primeiros anos, ocorrendo um aumento significativo no quarto ano, embora não diferindo da concentração do se gundo ano.

A concentração de magnésio na folha $(0,37 \%)$, obtida no quarto ano, foi superior à média apresentada por SHORROCKS (1965a) em ärvores adultas, que obteve $0,24 \%$, e também superior às con centrações médias apresentadas por PUSHPARAJAH (1977) em ärvores adultas $(0,246 \%$ para os clones AVROS, $0,241 \%$ para os clones PR; e $0,24 \%$ para os clones RRIM).

A Tabela 9, que apresenta a concentração de magnésio nas diversas partes do tronco em função da idade, mostra que não houve uma variação regular entre essas duas variāveis. A concentração obtida no quarto ano, $0,15 \%$ para a base do tronco, foi quase igual à apre sentada por SHORROCKS (1965a) em ärvores adultas, ou seja, 0,12\%.

A concentração de magnésio nas diversas partes dos gaThos, observada na Tabela 10, variou do terceiro para o quarto ano, aumentando nos galhos secos, permanecendo a mesma na ponta dos galhos pri 
mários e diminuindo na sua base. No quarto ano, os galhos secos apresentaram concentrações superiores às da ponta dos galhos primärios, que por sua vez, apresentaram maiores concentrações em relação à sua base, devido à maior intensidade de crescimento existente na ponta. As concentrações obtidas no ültimo ano $(0,31 \%$ para galhos secos e 0,20 e $0,12 \%$ para ponta e base dos galhos primärios, respectivamente) foram diferentes das obtidas por SHORROCKS (1965a) em ärvores adultas $(0,12 \%$ para galhos verdes e $0,09 \%$ para os galhos restantes), podendo ser resul tado da utilização de clones diferentes.

\subsubsection{Acümulo}

A Tabela 7 apresenta a quantidade total de magnésio acu mulada pela planta em função da idade. Nota-se que a planta acumulou quantidades crescentes desse elemento, com o quarto ano apresentando o maior aumento. Os resultados obtidos por SHORROCKS (1965a) são apenas parcialmente equivalentes a estes, pois esse autor obteve aumento na absorção de quase 7 vezes do primeiro para o segundo ano, bem diferente do obtido nas condições do Acre. A diferença nas quantidades acumuladas também são grandes, pois enquanto esse autor obteve um acūmulo de $2,1 \mathrm{~kg} / \mathrm{ha}$ no primeiro ano e $62,8 \mathrm{~kg} / \mathrm{ha}$ no quarto ano, neste tra balho foi obtido $0,5 \mathrm{~kg} / \mathrm{ha}$ no primeiro ano e $5,3 \mathrm{~kg} / \mathrm{ha}$ no quarto ano. Uma das possiveis causas dessa grande diferença no acūmulo de magnésio è a utilização de clones diferentes.

A equação de regressão que melhor se ajustou à varia- 
ção da quantidade total de magnēsio em relação à idade foi a quadrātica, apresentada na Figura 13, juntamente com a curva correspondente.

A variação da quantidade de magnēsio nas folhas em função da idade é apresentada na Tabela 8. A absorção de magnē sio pelas folhas aumentou muito pouco do primeiro para o segundo ano, duplicando do segundo para o terceiro ano e aumentando cerca de 3,4 vezes no ültimo ano, quando apresentou 0 a cūmulo de $1,84 \mathrm{~kg} / \mathrm{ha}$ de magnésio.

Quanto à variação da quantidade de magnēsio no tronco, apresentada na Tabela 9, nota-se que ocorreram aumentos crescen tes no acümulo desse elemento com o passar do. tempo, com cer ca de 1,5 vezes do primeiro para o segundo ano, 1,8 vezes do segundo para o terceiro ano, e 2,6 vezes do terceiro para o quar to ano. A base do tronco apresentou quantidades sempre superiores ao meio e à ponta, sendo que no ültimo ano a quantidade total de magnésio acumulada pelo tronco foi de $2,06 \mathrm{~kg} / \mathrm{ha}$, quan tidade acima daquela acumulada pelas folhas.

Através da Tabela 10, que apresenta a variação da quantidade de magnésio nos galhos, observa-se que houve um grande aumento do tercei ro parao quarto ano, com cerca de 8,4 vezes. No ültimo ano, os galhos secos apresentaram quantidades superioresà ponta e base dos galhos primários, sendo que a quantidade total de magnésio acumulada nesse ano foi de $1,39 \mathrm{~kg} / \mathrm{ha}$, inferior às acumuladas pelas folhas e tronco. 
Considerando a quantidade total de magnésio na planta como sendo igual a $100 \%$, a distribuição porcentual desse elemento em cada örgã̃o é apresentada na Figura 14. 0 magnésio acumulou-se em maio res quantidades no tronco, apresentando $62,6 \%$ no primeiro ano, atingindo um valor māximo de $71,7 \%$ no segundo e decrescendo rapidamente para $39,0 \%$ no quarto ano. Esses resultados contradizem os obtidos por LIM (1977), para o qual hä maior acümulo de magnésio nos galhos. Nas fo lhas, a quantidade de magnésio variou $37,4 \%$ no primeiro ano até $34,7 \%$ no quarto ano, enquanto que os galhos apresentaram um porcentual de $26,3 \%$ no ültimo ano. Neste caso, tambēm nota-se uma tendência do acūmulo nos galhos ultrapassar o das folhas e tronco. 


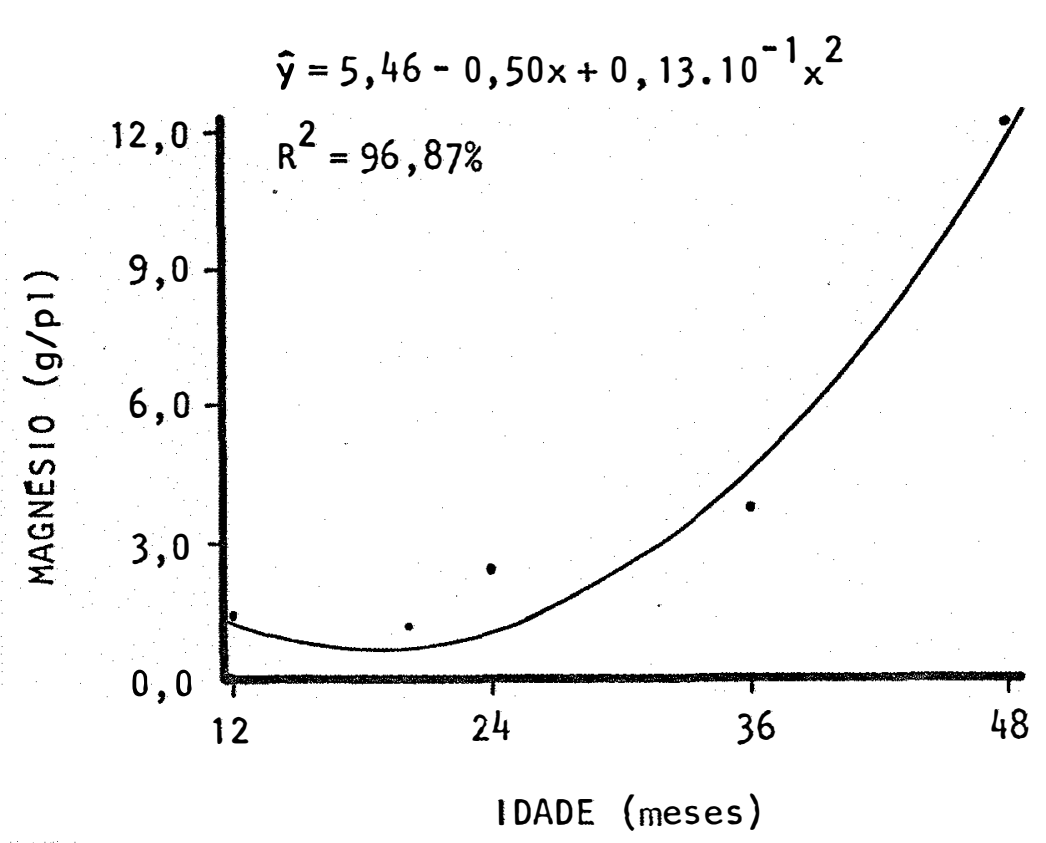

FIGURA 13 - Acūmulo total de magnésio na planta, em função da idade.

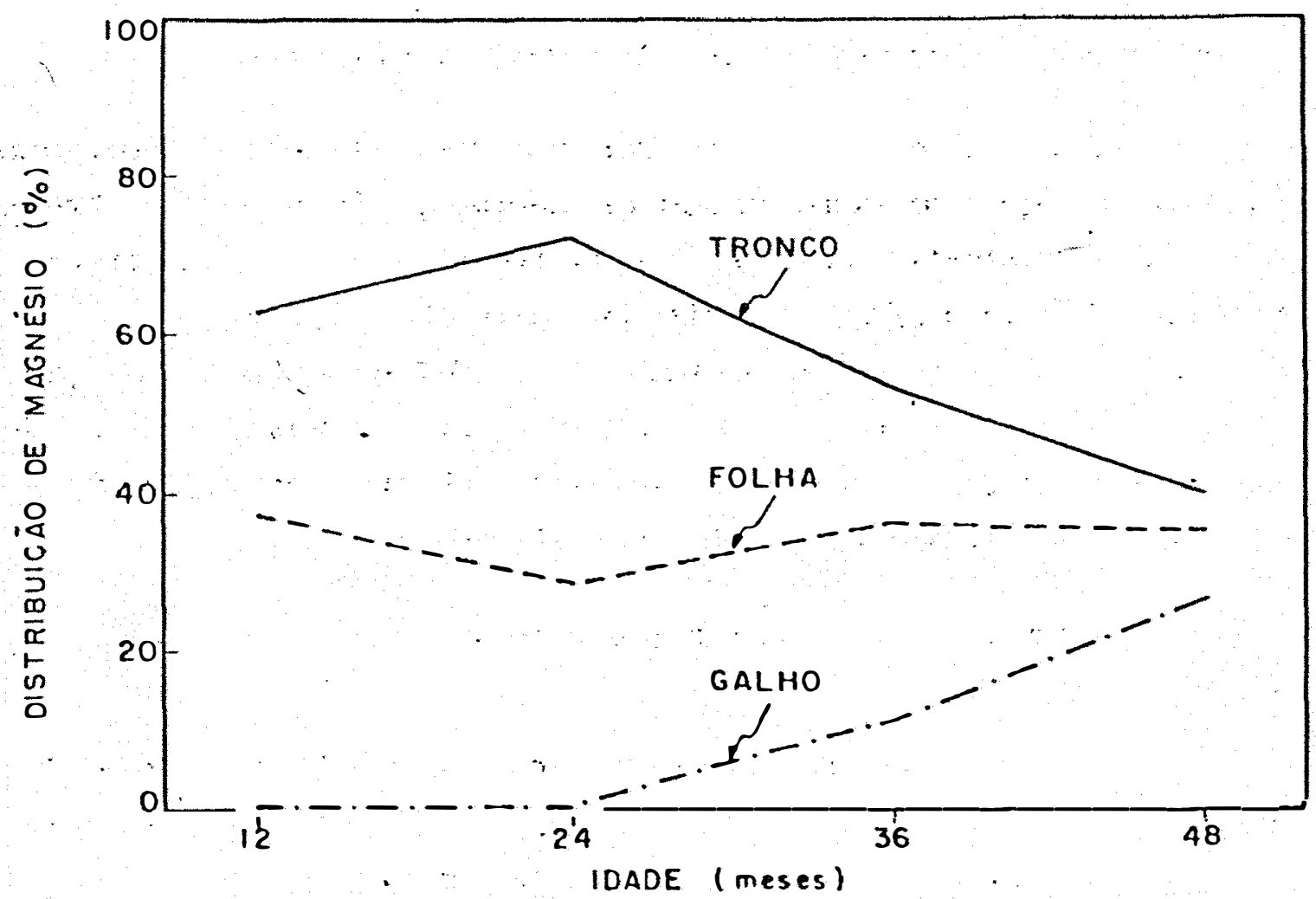

FIGURA 14 - Distribuição de magnēsio nos diversos órgãos da planta, em função da idade. 


\subsubsection{Enxofre}

\subsubsection{Concentração}

Os valores da concentração de enxofre nas folhas em fun ção da idade estão apresentados na Tabela 8. Não houve diferenças na concentração de enxofre durante os três primeiros anos, ocorrendo um au mento significativo no quarto ano em relação ao primeiro. Ajustou-se regressão linear para esse tipo de variação, estando apresentada, junta mente com a reta correspondente, na Figura 15 .

No ültimo ano, a concentração de enxcfre na folha $(0,15 \%)$ foi inferior à média apresentada por SHORROCKS(1965a) em árvores adultas $(0,22 \%)$.

Atravēs da Tabela 9, observa-se que a concentração de enxofre nas diversas partes do tronco não apresentou uma tendência regular com o aumento da idade, sendo que no quarto ano a base do tronco apresentou uma concentração de $0,07 \%$, praticamente igual à obtida por SHORROCKS (1965a) em ārvores adultas $(0,06 \%)$.

A Tabela 10 ,que apresenta a concentração de enxofre nas diversas partes dos galhos em função da idade,mostra que ocorreu uma diminuição nessa concentração do terceiro para o quarto ano. A ponta dos galhos primários apresentou uma concentração superior à da sua base, provavelmente devido à maior intensidade de crescimento existente na ponta, sendo que os galhos secos apresentaram a concentração mais baixa. As concentraçōes obtidas no quarto ano $(0,05 \%$ para galhos se- 
cos e 0,08 e 0,06\% para ponta e base dos galhos primários, respectivamente) foram diferentes das obtidas por SHORROCKS (1965a) em ärvores adultas $(0,12 \%$ para galhos verdes e $0,06 \%$ para os galhos restantes).

\subsubsection{Acúmulo.}

A quantidade total de enxofre acumulada na planta em função da idade encontra-se na Tabela 7. A absorção de enxofre pelas plantas foi baixa inicialmente, correspondendo ao pequeno desenvolvimen to da planta nesse periodo. Entretanto, no terceiro e quarto anos ocorreram aumentos significativos. Esses resultados são conträrios aos obtidos por SHORROCKS (1965a), que obteve um grande aumento na absorção do primeiro para o segundo ano, diminuindo em relação ao terceiro e quarto anos. Também observa-se que as quantidades de enxofre extraidas pela seringueira, obtidas pelo referido autor, são bem maiores quando comparadas com as obtidas neste trabalho. Enquanto na Malásia a planta retirou $1,2 \mathrm{~kg} / \mathrm{ha}$ no primeiro ano, atingindo $48,1 \mathrm{~kg} / \mathrm{ha}$. no quarto ano; nas condições do Acre a planta retirou apenas $0,14 \mathrm{~kg} / \mathrm{ha}$ no primeiro ano e $1,88 \mathrm{~kg} / \mathrm{ha}$ no quarto ano. Essa diferença pode ter sido causada, possivelmente, pela utilização de clones diferentes.

A curva correspondente à variação da quantidade de enxofre em relação à idade è apresentada na Figura 16 , juntamente com a equação de regressão quadrātica, que foi aquela que mais se ajustou a esse tipo de variação.

0 acūmulo de enxofre nas folhas, mostrado na Tabela 8, 
quase não variou do primeiro para o segundo ano,triplicando do segundo para o terceiro ano e apresentando um aumento de 2,7 vezes do terceiro para o quarto ano. 0 enxofre foi o macronutriente acumulado em menores quantidades pelas folhas, atingindo $0,75 \mathrm{~kg} / \mathrm{ha}$ no quarto ano.

Com relação à variação da quantidade de enxofre no tron co, apresentada na Tabela 9, observa-se que houve um aumento de 2,4 ve zes do primeiro para o segundo ano, de 2,0 vezes do segundo para o ter ceiro ano e de 2,2 vezes do terceiro para o quarto ano. Durante os quatro anos, a distribuição da quantidade desse elemento nas partes do tronco foi sempre a seguinte: base > meio > ponta, sendo que no quarto ano o tronco apresentou um acúmulo estimado de $0,85 \mathrm{~kg} / \mathrm{ha}$, superior ao acumulado pelas folhas.

A variação da quantidade de enxofre nos galhos em função da idade é apresentada na Tabela 10. Houve um grande aumento do terceiro para o quarto ano, com cerca de 4,7 vezes, ocorrendo um acúmulo de $0,44 \mathrm{~kg} / \mathrm{ha}$ nesse ültimo ano, inferior ao acumulado pelas folhas e tronco. A base dos galhos primärios apresentaram quantidades superiores à sua ponta, provavelmente devido à base possuir maior peso de matēria seca do que a ponta, enquanto que os galhos secos apresentaram as menores quantidades.

A distribuição porcentual de enxofre em cada örgão da planta, considerando a quantidade total desse elemento na planta como sendo igual a 100\%, è apresentada na Figura 17. 0 tronco acumulou as maiores quantidades de enxofre nos très primeiros anos, apresentando 
$58,4 \%$ do primeiro, atingindo um mäximo de $67,7 \%$ no segundo e decrescen do rapidamente até o quarto ano, quando apresentou $36,7 \%$. As folhas acumularam $40,6 \%$ de enxofre no primeiro ano, decrescendo para $32,3 \%$ no segundo, e aumentando novamente até atingir $40,1 \%$ no quarto ano. Neste ültimo ano, o acúmulo nas folhas ultrapassou o do tronco, não poden do-se prever se essa relação serā mantida. 0 mesmo ocorre com os gaIhos, que apresentaram um aumento praticamente linear na absorção de en xofre, atingindo $23,2 \%$ no quarto ano, mas não podendo-se afirmar se esse aumento continuará nos anos seguintes. 


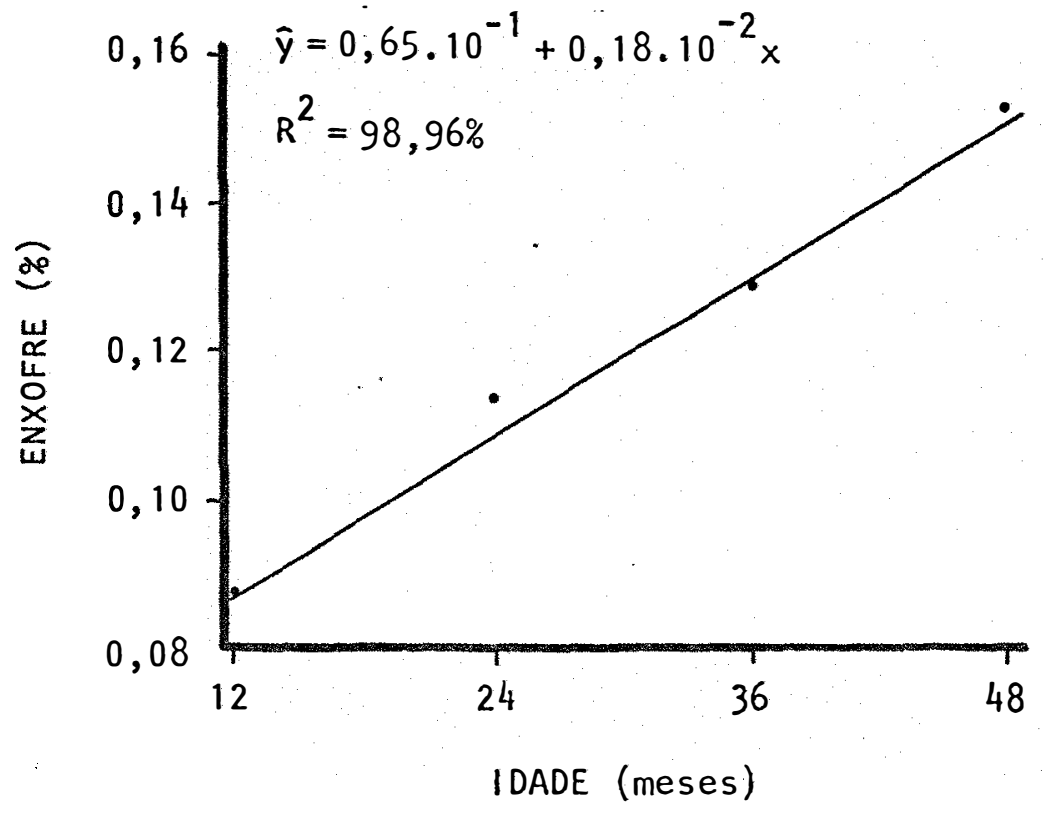

FIGURA 15 - Concentração de enxofre nas folhas, em função da idade.

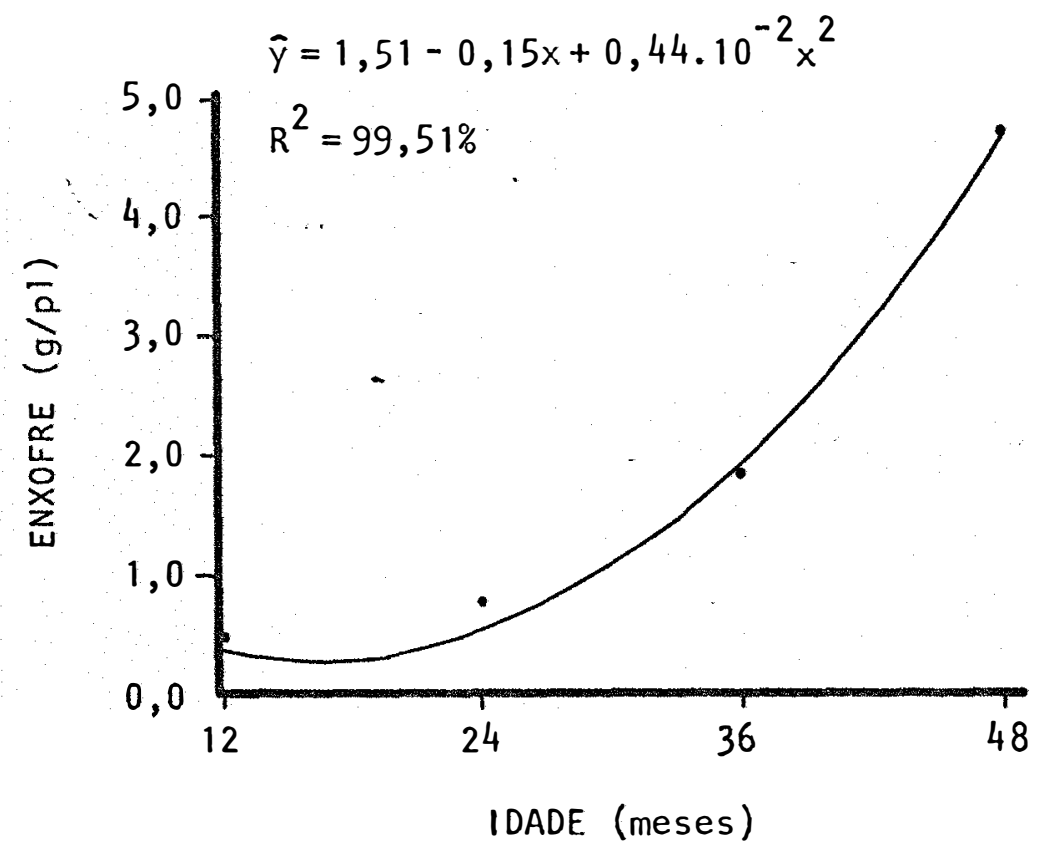

FIGURA 16 - Acúmulo total de enxofre na planta, em função da idade. 


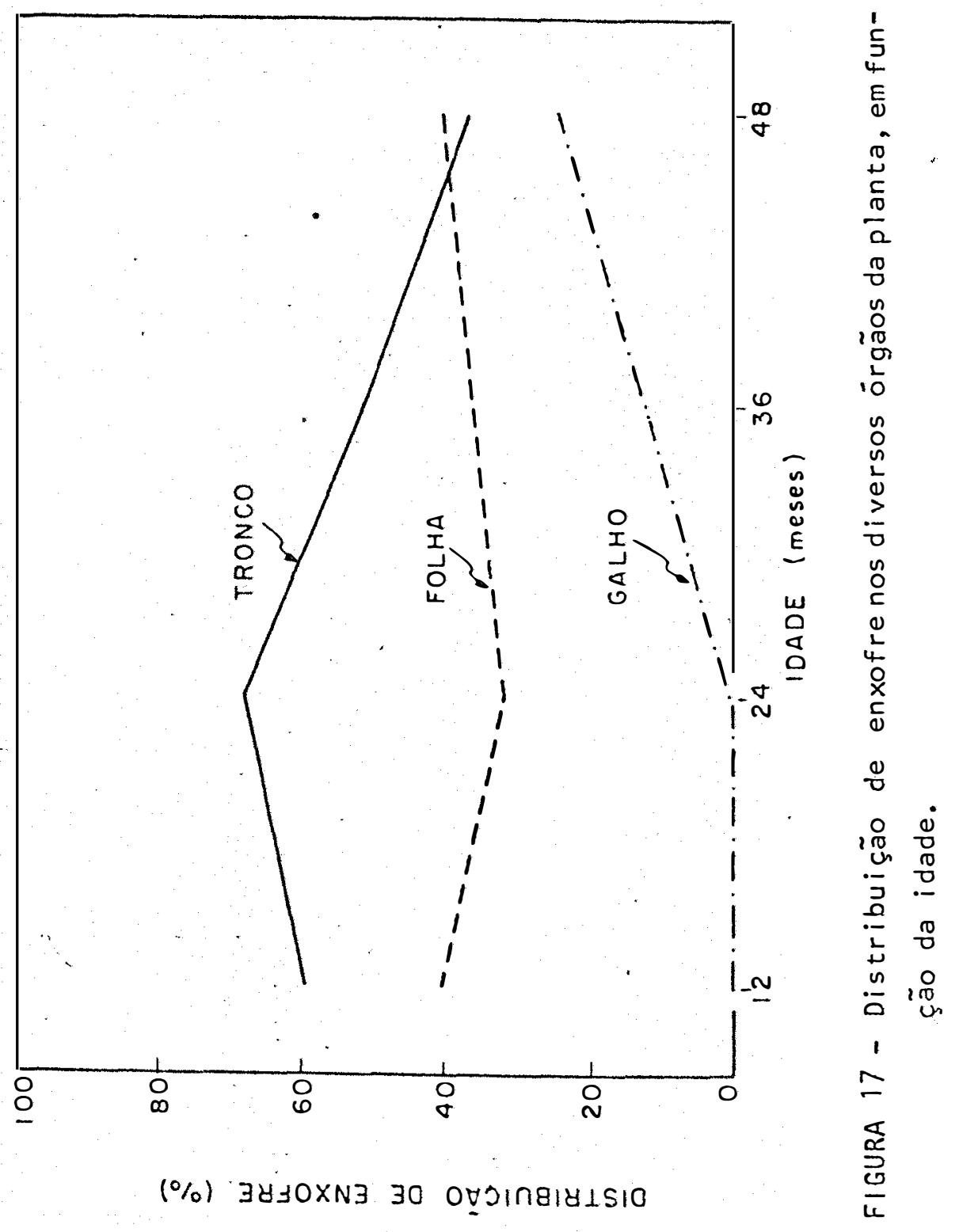




\subsection{Extração de Micronutrientes.}

\subsubsection{Boro}

\subsubsection{Concentração}

A concentração de boro nas folhaș, com base no peso de matéria seca, em função da idade, è apresentada na Tabela 12. Não se ajustou nenhuma regressão para esse tipo de variação,pois não houve di ferenças significativas nas concentrações de boro durante os quatro anos. No ültimo ano, a concentração de boro na folha $(23,2 \mathrm{ppm})$ foi bem prōxima à média apresentada por SHORROCKS (1965a) em ärvores adultas, ou seja, 29 ppm.

A Tabela 13, que apresenta a concentração de boro nas diversas partes do tronco em função da idade, mostra que essa concentra ção não apresentou uma tendência regular com o aumento da idade, sendo que no quarto ano a base do tronco apresentou uma concentração de 6,7 ppm, superior à obtida por SHORROCKS (1965a) em ärvores adultas (4 ppm).

A concentração de boro nas diversas partes dos galhos em função da idade, observada na Tabela 14, indica que essa concentra ção diminuiu do terceiro para o quarto ano, sendo que os galhos secos apresentaram concentrações superiores à ponta dos galhos primärios, e estes em relação à sua base, provavelmente devido à maior intensidade de crescimento existente na ponta. As concentrações obtidas no quarto ano (11,2 ppm para galhos secos e 9,8 e 8,0 ppm para ponta e base dos galhos primários respectivamente), foram bem diferentes das obtidas por SHORROCKS (1965a) em ärvores adultas (6 ppm para galhos verdes e 3 ppm para os galhos restantes). 
4.3.1.2. Acūmulo,

A Tabela 11 apresenta a quantidade total de boro acumulada na planta em função da idade. Nota-se que nos dois primeiros anos a absorção de boro não variou, coincidindo com o pequeno desenvolvimen to da planta nesse período, enquanto que o terceiro ano apresentou um aumento de mais de 5,0 vezes em relação ao segundo, e ocorrendo um pequeno, mas significativo, aumento do terceiro para o quarto ano. Esses resultados não concordam com os obtidos por SHORROCKS (1965a), que obte ve um aumento de 8,0 vezes do primeiro para o segundo ano, diminuindo em relação ao terceiro e quarto anos. Comparando-se ainda, os resultados obtidos neste trabalho aos de SHORROCKS (1965a) nota-se que enquanto esse autor obteve na Malásia um acūmulo de $10 \mathrm{~g} /$ ha no primeiro ano e $300 \mathrm{~g} / \mathrm{ha}$ no quarto ano, as condições do Acre apresentaram um acü mulo de $3,7 \mathrm{~g} / \mathrm{ha}$ no primeiro ano e $29,4 \mathrm{~g} / \mathrm{ha}$ no quarto ano. Uma das possíveis causas dessa grande diferença é a utilização de.clones diferentes.

'A equação de regressão que melhor se ajustou à varia ção da quantidade total de boro em relação à idade foi a quadrática,as sinalada,juntamente com a curva correspondente, na Figura 18 .

O acúmulo de boro nas folhas, mostrado na Tabela 12, quase não variou do primeiro para o segundo ano, com um incremento de 3,4 vezes do segundo para o terceiro ano e de 2,1 vezes do terceiro para o quarto ano. Nesse ültimo ano, as folhas apresentaram uma quantidade estimada de boro de $13,8 \mathrm{~g} / \mathrm{ha}$, superior apenas à quantidade de cobre nesse örgão. 
Quanto à variação da quantidade de boro no tronco, apre sentada na Tabela 13, nota-se que nãohouve variação do primeiro para o segundo ano, ocorrendo um acréscimo de 5,6 vezes do segundo para o ter ceiro ano, e com o quarto ano não apresentando nenhuma variação em relação ao terceiro. Durante os quatro anos, a base do tronco apresen tou quantidades superiores ao meio e à ponta, sendo que no ūltimo ano a quantidade de boro acumulada pelo tronco foi de $9,1 \mathrm{~g} / \mathrm{ha}$, menor que a acumulada pelas folhas.

Atravēs da Tabela 14, que apresenta a variação da quantidade de boro nos galhos, observa-se que houve um aumento de 3,4 vezes do terceiro para o quarto ano, com um acümulo de $6,5 \mathrm{~g} / \mathrm{ha}$ nesse úl timo ano, inferior ao acumulado pelas folhas e tronco. A base dos gaIhos primārios apresentaram quantidades superiores à sua ponta, provavelmente devido à base possuir maior peso de matéria seca do que a pon ta, enquanto que os gal hos secos apresentaram as menores quantidades.

Considerando a quantidade total de boro na planta como sendo igual a $100 \%$, a distribuição porcentual desse elemento em cada órgão è apresentada na Figura 19. 0 tronco acumulou as maiores quanti dades de boro, variando de $51,4 \%$ no primeiro ano até $31,0 \%$ no quarto ano, sendo que neste ültimo anootronco foi superado pelas folhas, as quais apresentaram uma variação de $48,6 \%$ no primeiro ano até $46,9 \%$ no quarto ano. Os galhos acumularam $10,0 \%$ do boro total no terceiro ano e $22,1 \%$ no quarto ano, podendo, nos anos seguintes,ultrapassar a quantidade existente no tronco. 


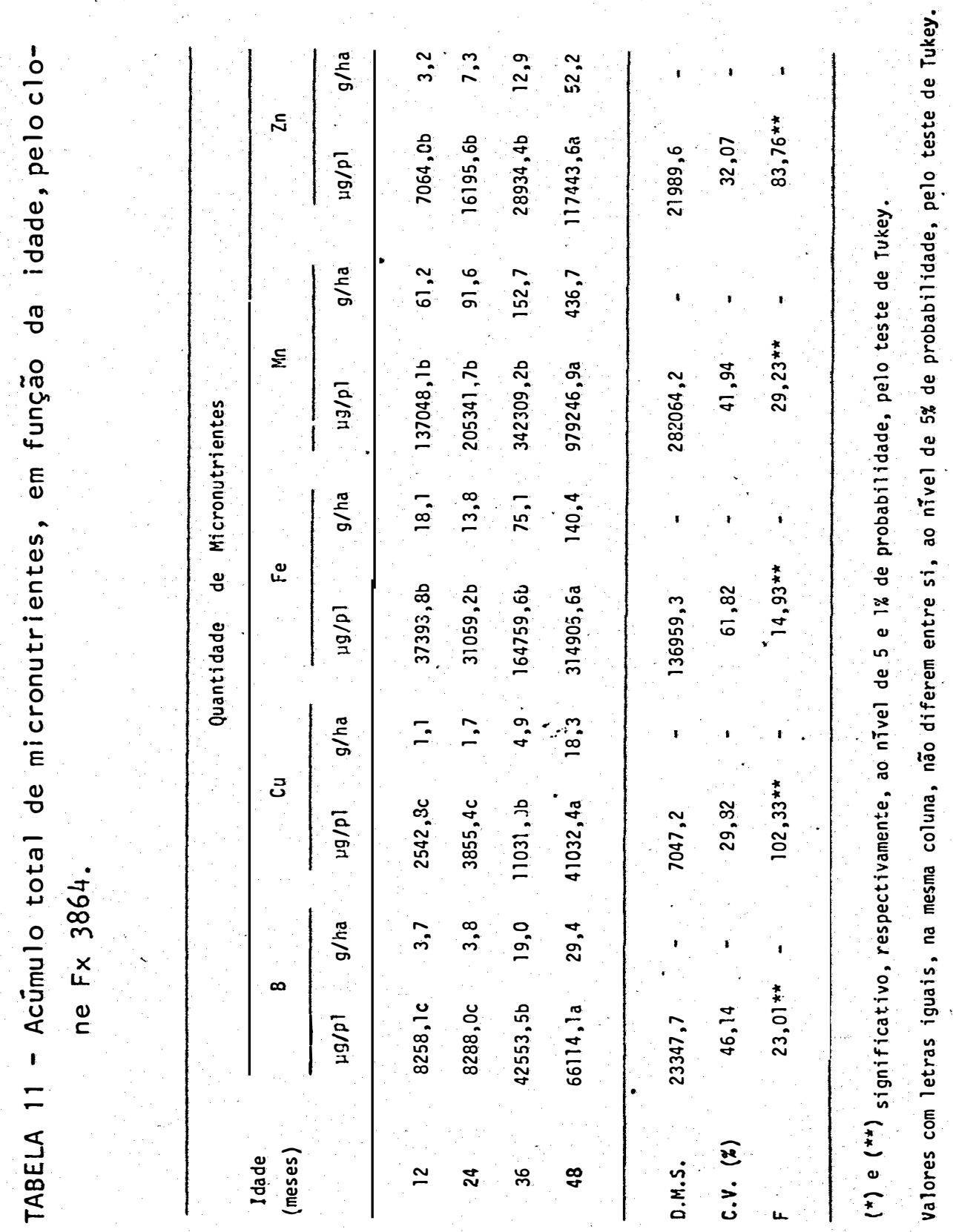




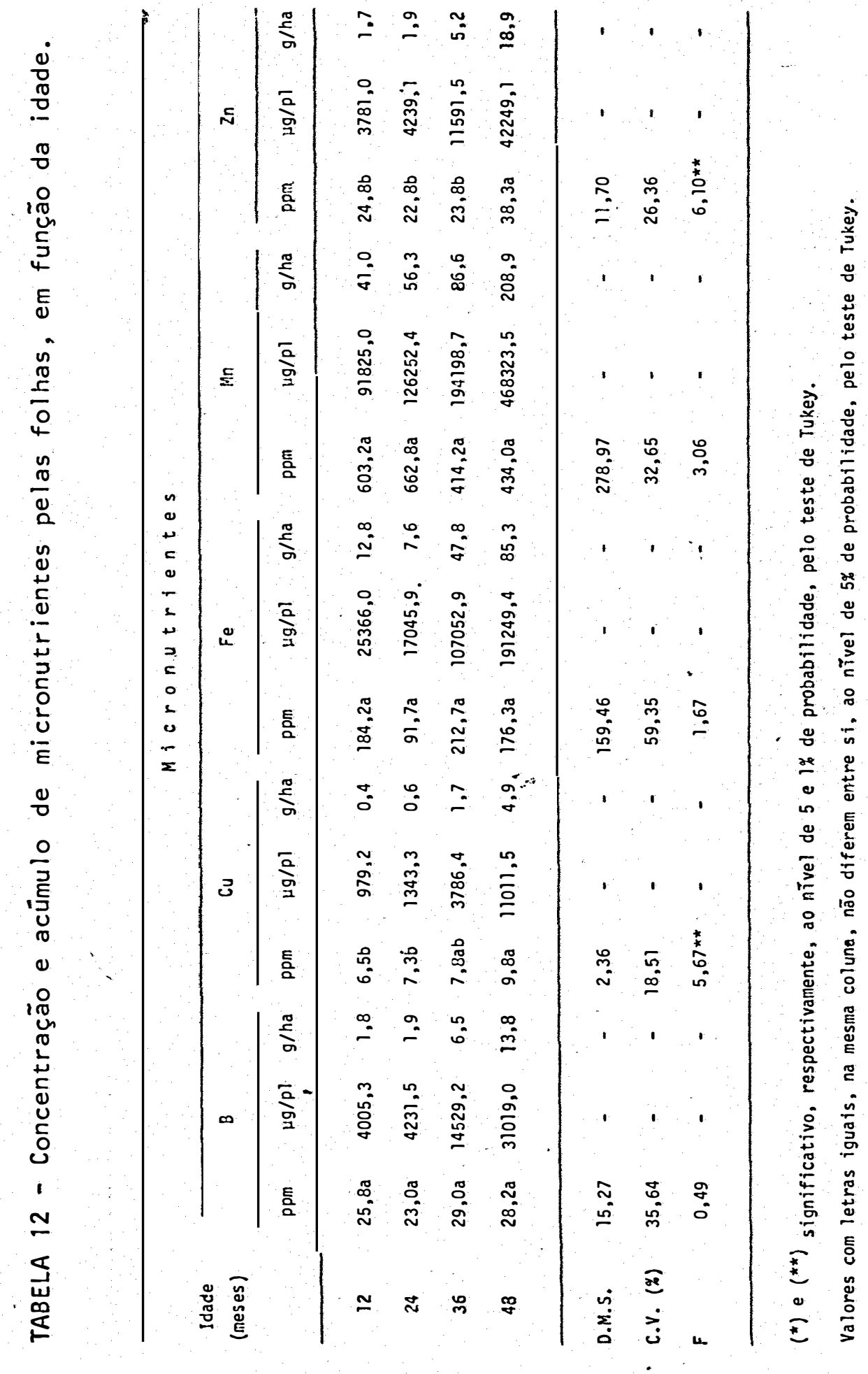




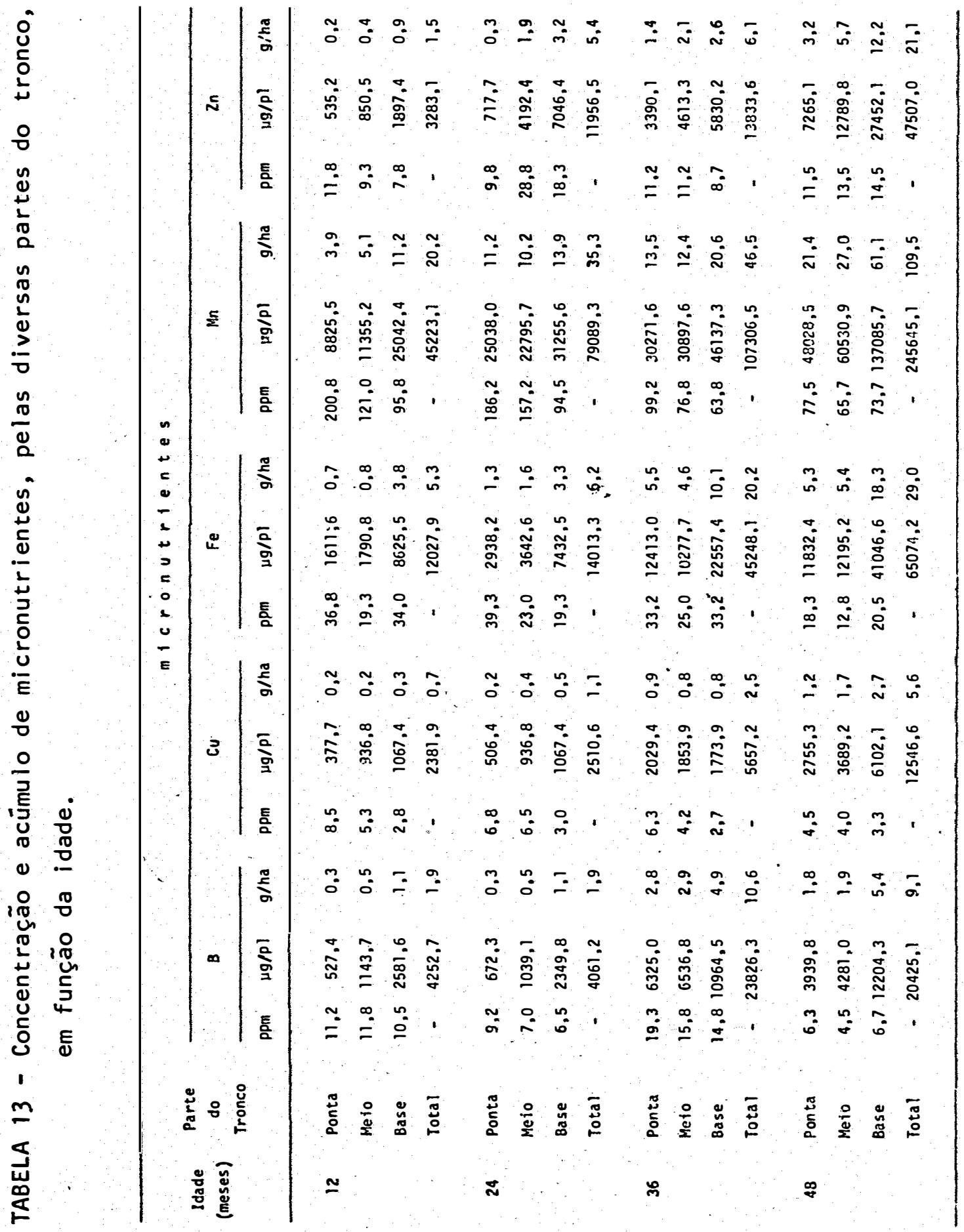




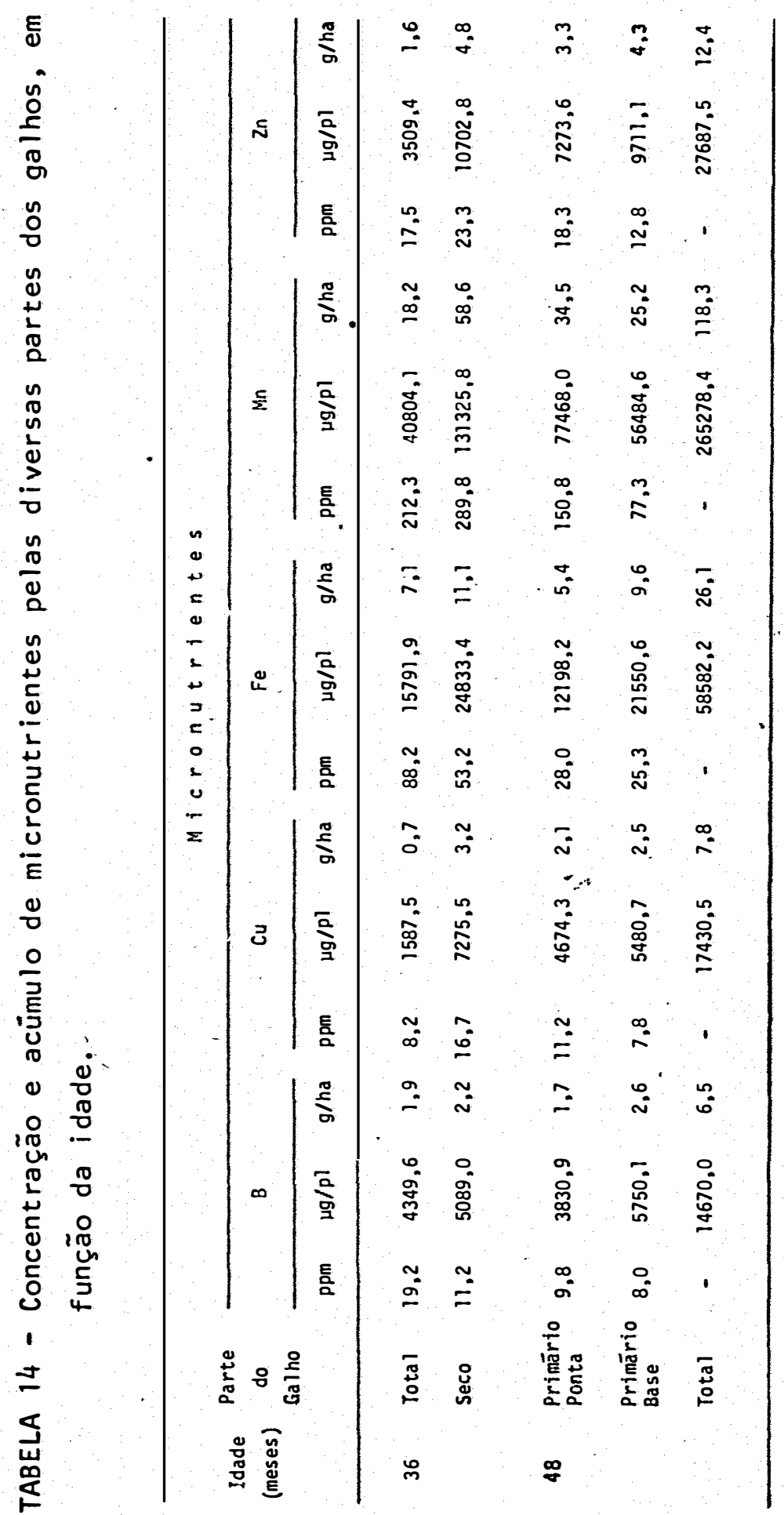




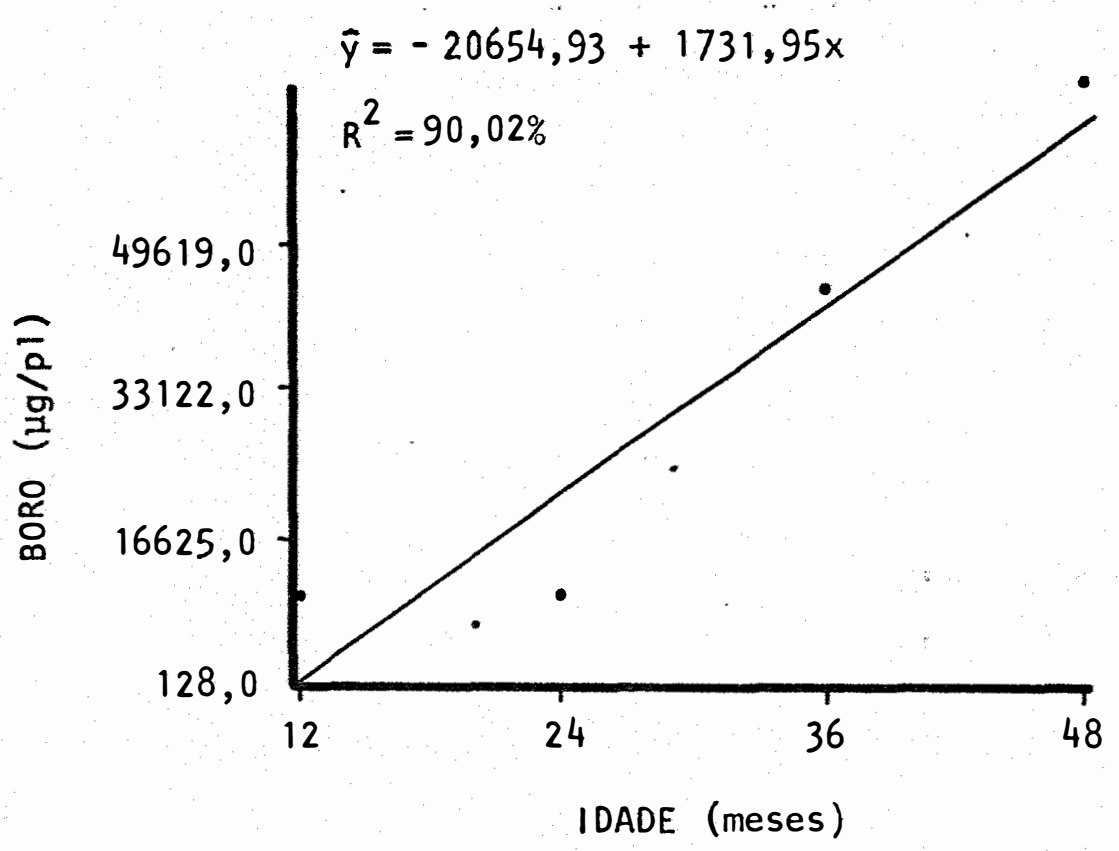

FIGURA 18 - Acúmulo total de boro na planta, em função da idade.

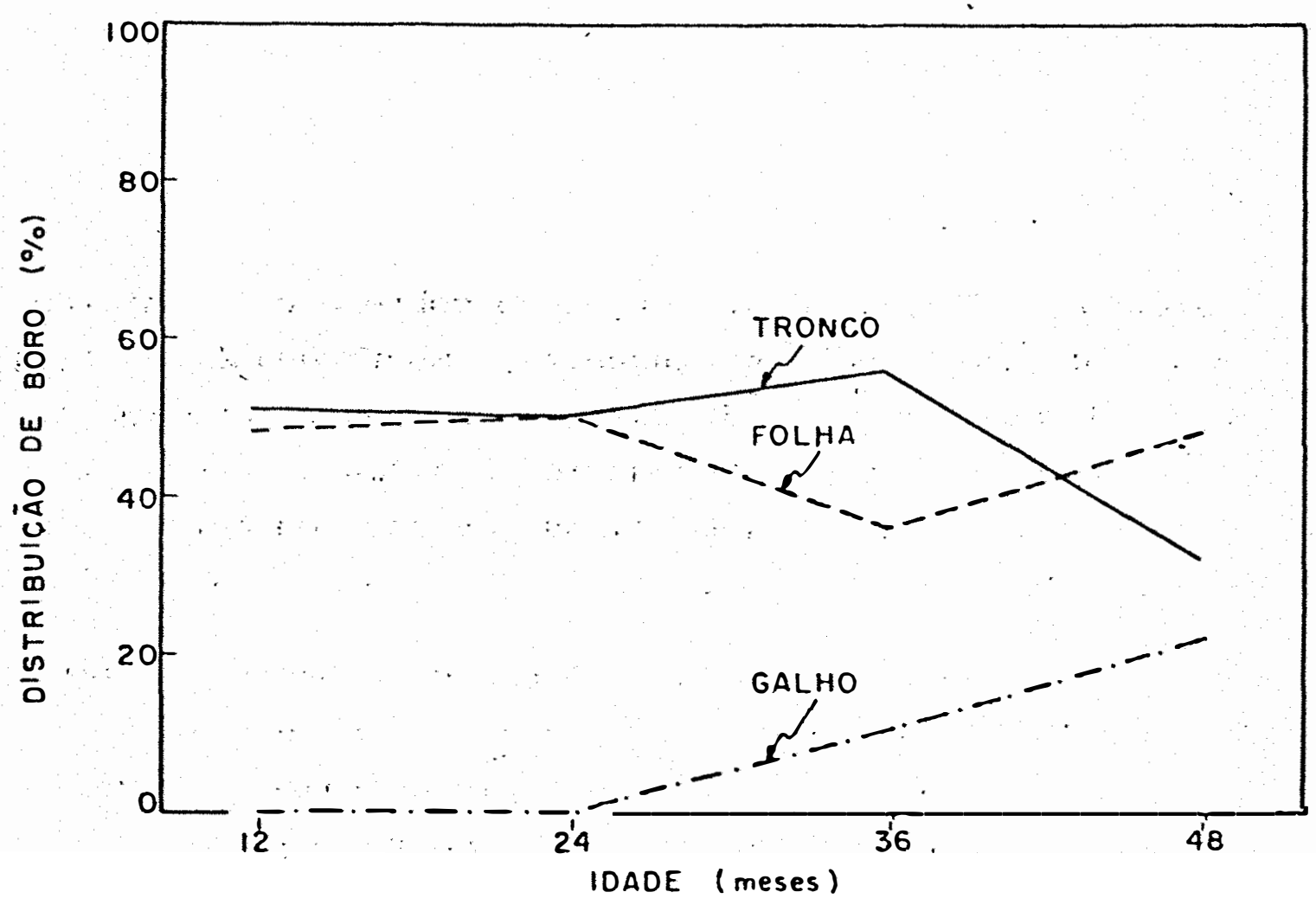

FIGURA 19 - Distribuição de boro nos diversos örgãos da planta, em função da idade. 


\subsubsection{Cobre}

\subsubsection{1: Concentração}

Os dados analíticos referentes à concentração de cobre nas folhas combase no peso de matéria seca, em função da idade, são apresentados na Tabela 12. Não houve variação na'concentração durante os três primeiros anos, ocorrendo um aumento significativo apenas no quarto ano em relação ao primei ro e segundo anos. Ajustou-se regressão linear para esse tipo de variação, sendo apresentada, juntamente com a reta correspondente, na Figura 20. A concentração obtidanoūl timo ano (9,8 ppm) foi inferior à obtí da por SHORROCKS (1965a) em ärvores adultas (11 ppm).

Atravēs da Tabela 13, que apresenta a concentração de cobre nas diversas partes do tronco em função da i dade, observa-se que essa concen tração diminuiucomo aumento da idade, sendo que a ponta do tronco sempre apresentou concentrações superiores ao meioe à base. A concentração obti da no quarto ano, 4,5 ppmpara a ponta do tronco, foi superior à obtida por SHORROCKS (1965a) em ärvores adultas (3 ppm). Esses valores são muito importantes, poi s os teores de cobre na borracha acima de 9 ppm não são tolerados, devido a esse elemento catal izar as reações de oxidação que conduzem ao envelhecimento precoce da borracha.

Com relação à concentração de cobre nas diversas partes dos galhos em função da idade, observada na Tabela 14, nota-se que a con centração desse elemento variou do terceiro para o quarto ano, aumentan do para os galhos secos e ponta dos galhos primärios e diminuindo para a base dos galhos primärios. A maior concentração existente na ponta em relação à base dos galhos primärios pode ser explicada pelo 
fato de ocorrer uma maior intensidade de crescimento na ponta. Compa rando-se os resultados obtidos no ültimo ano com os obtidos por SHORROCKS (1965a) em ärvores adultas, . nota-se que são diferentes, pois enquanto esse autor cita uma concentração média de 11 ppm nos galhos e 4 ppm nos galhos restantes na região da Maläsia, nas condições do Acre obteve-se 16,7 ppm nos galhos secos e 11,2 e 7,8 ppm na ponta e base dos galhos primärios, respectivamente. Essa diferença pode ser resul tado da utilização de clones diferentes nos dois experimentos.

\subsubsection{Acümulo}

A quantidade total de cobre acumulada na planta em função da idade encontra-se na Tabela 11. 0 cobre é absorvido em quantidades crescentes pela seringueira, sendo que a absorção é lenta inicial mente, correspondendo ao pequeno desenvolvimento da planta nesse período, mas quase triplicando do segundo para o terceiro ano e aumentando cerca de 3,7 vezes do terceiro para o quarto ano. Esses resultados não concordam com os obtidos por SHORROCKS (1965a), que obteve um aumento de 4 vezes do primeiro para o segundo ano e um incremento excepci onal no terceiro ano. Observa-se, também, que as quantidades de cobre absorvidas pela seringueira nas condições do Acre são bem menores que as obtidas por SHORROCKS (1965a). Enquanto esse autor registrou uma absurção de $10 \mathrm{~g} / \mathrm{ha}$ no primeiro ano e $250 \mathrm{~g} / \mathrm{ha}$ no quarto ano, neste tra balho obteve-se $1,1 \mathrm{~g} / \mathrm{ha}$ no primeiro ano e $18,3 \mathrm{~g} / \mathrm{ha}$ no quarto ano. Uma das possíveis explicações para essa diferença é a utilização de clones diferentes nos dois experimentos. 
A curva correspondente à variação da quantidade de cobre em relação à idade é apresentada na Figura 21 , juntamente com a equação de regressão quadrātica,que foi aquela que mais se ajustou a esse tipo de variação.

A quantidade de cobre acumulada pelas folhas, observada na Tabela 12, apresentou um incremento bem pequeno do primeiro para o segundo ano, aumentando 2,8 vezes do segundo para o terceiro ano e 2,9 vezes do terceiro para o quarto ano. 0 cobre foi o micronutriente acumulado em menores quantidades pelas folhas, as quais apresentaram. $4,9 \mathrm{~g} / \mathrm{ha}$ no quarto ano.

A Tabela 13 apresenta o acúmulo de cobre no tronco em função da idade. Houve um aumento de 2,3 vezes do seğundo para o terceiro ano e de 2,2 vezes do terceiro para o quarto ano,ocorrendo, portanto, um incremento anual menor em relação às folhas. A base do tron co apresentou quantidades superiores ao meio e à ponta, devido ao seu maior peso de matēria seca. No ültimo ano, a quantidade total acumula. da pelo tronco foi de $5,6 \mathrm{~g} / \mathrm{ha}$, superior à acumulada pelas folhas.

Com relação à variação da quantidade de cobre nos gaIhos, apresentada na Tabela 14, observa-se que houve um. incremento de 11,1 vezes do terceiro para o quarto ano,ocorrendo um acúmulo de 7,8 g/ha nesse ültimo ano, quantidade superior à das folhas e tronco. Os ga Ihos secos apresentaram quantidades superiores às da base dos galhos primärios, e estes em relação à sua ponta, devido à base possuir maior peso de matéria seca do que a ponta. 
A distribuição porcentual de cobre em cada örgão da planta, considerando a quantidade total desse elemento na planta como sendo igual a 100\%, è apresentada na Figura 22. 0 cobre acumulou-se em maiores quantidades no tronco durante os três primeiros anos, apre sentando $63,6 \%$ no primeiro e $30,6 \%$ no quarto ano. 0 porcentual nas fo Thas quase não variou nos três primeiros anos (mëdia de $35,4 \%$ ), decres cendo para $26,8 \%$ no quarto ano. Mesmo com esse decréscimo, a quantida de nas folhas, nesse ültimo ano, quase se iguala à do tronco. Os gaIhos apresentaram um grande aumento no quarto ano, com um porcentual de $42,6 \%$, ultrapassando as folhas e tronco. 


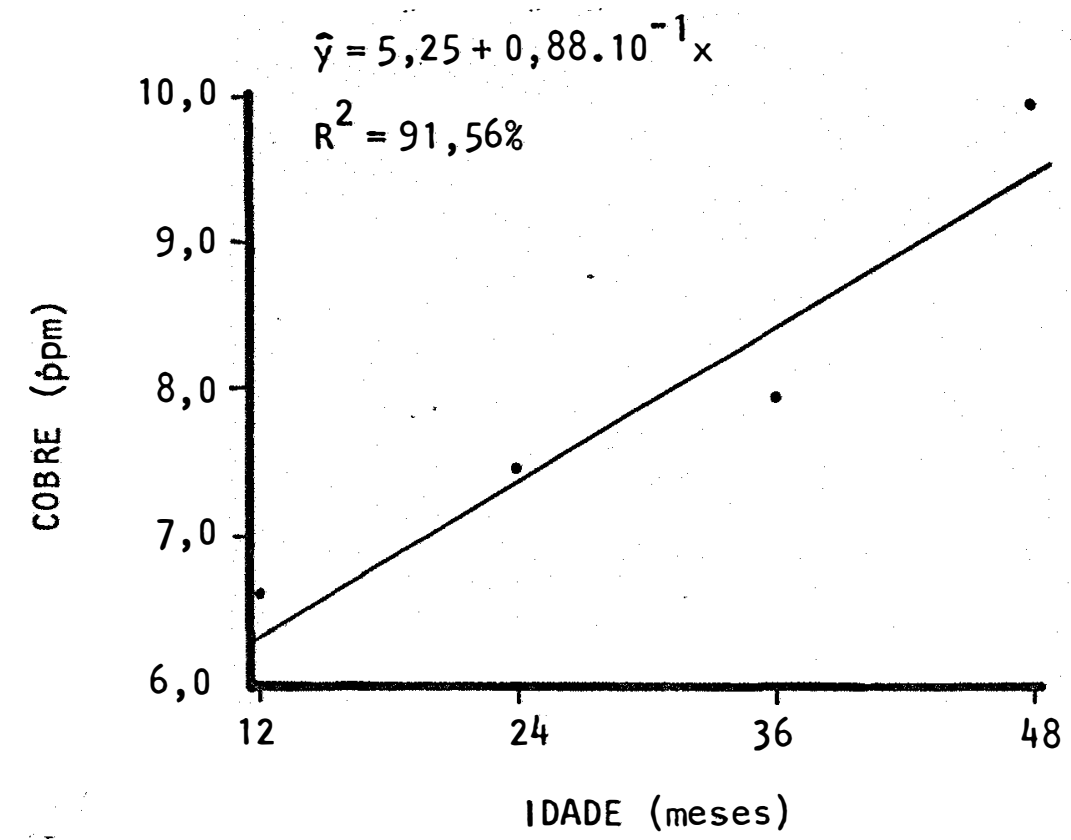

FIGURA 20 - Concentração de cobre nas folhas em função da idade.

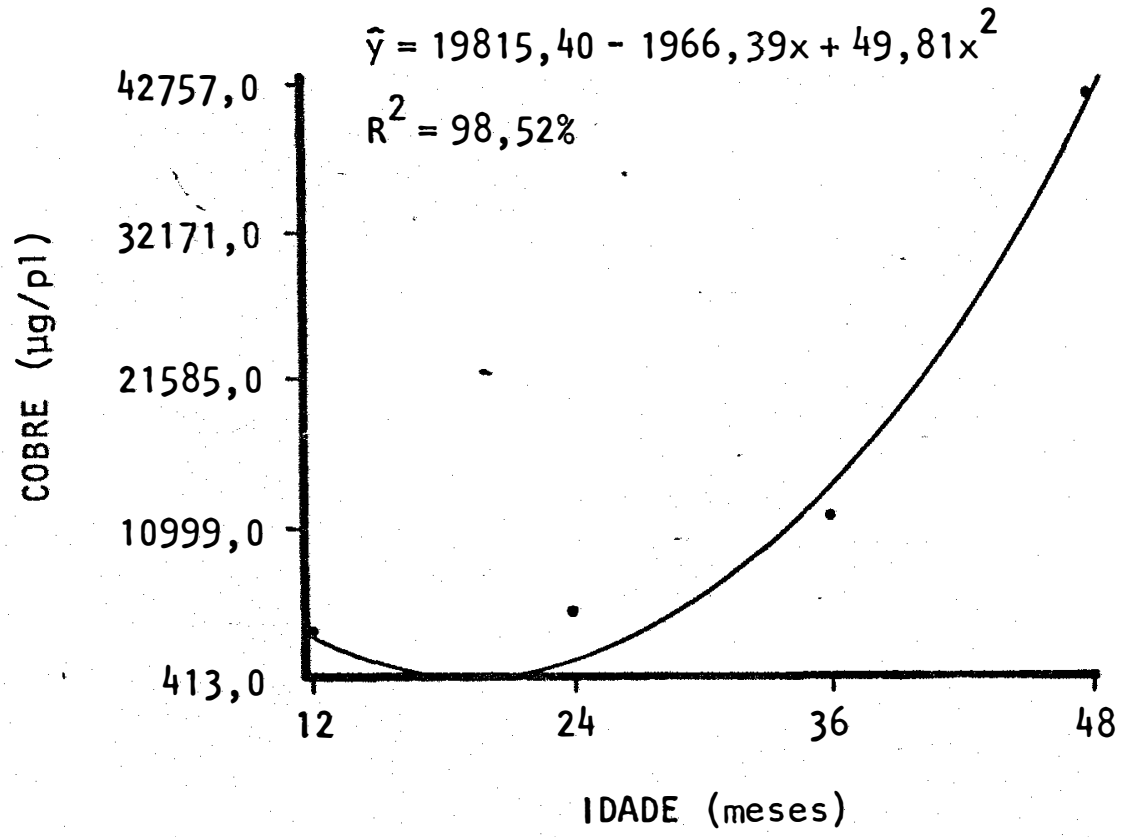

FIGURA 21 - Acúmulo total de cobre na planta, em função da idade. 


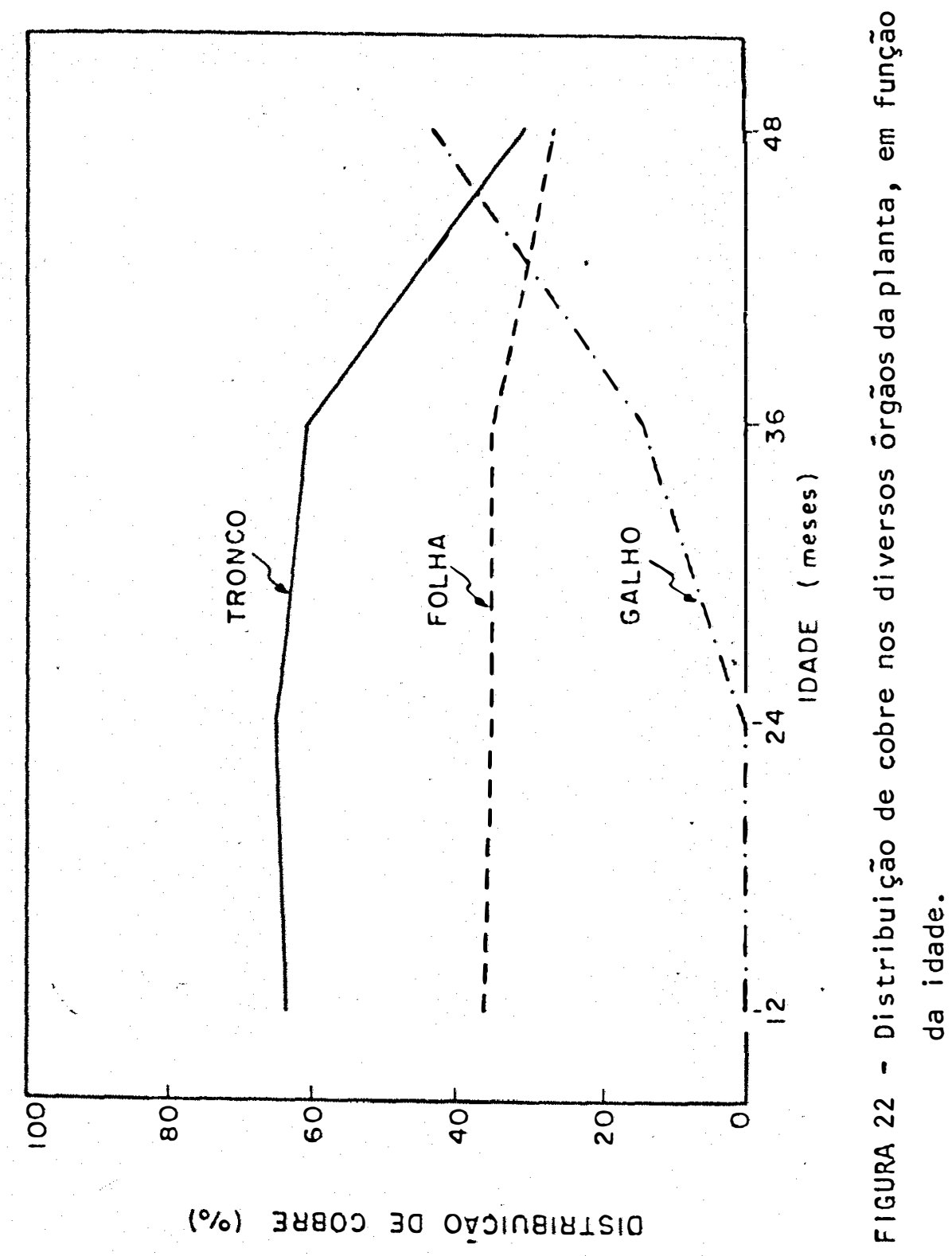




\subsubsection{Ferro}

\subsubsection{Concentração}

Os valores da concentração de ferro nas folhas, com ba se no peso da matéria seca, em função da idade, estão apresentados na Tabela 12. Não se ajustou nenhuma regressão para esse tipo de variação, pois não houve diferenças significativas nas concentraçōes de fer ro durante os quatro anos. No quarto ano, a concentração de ferro na folha (176,3 ppm) foi prōxima à média apresentada por SHORROCKS(1965a) em àrvores adultas (182 ppm).

A concentração de ferro nas diversas partes do tronco, mostrada pela Tabela 13, não apresentou uma tendência'regular com 0 aumento da idade, sendo que no quarto ano a base do tronco apresentou uma concentração de 20,5 ppm, inferior à obtida por SHORROCKS (1965a) em ärvores adultas (30 ppm).

A Tabela 14, que apresenta a concentração de ferro nas diversas partes dos galhos em função da idade, mostra que essa concentração diminuiu do terceiro para o quarto ano, com os galhos secos apresentando concentrações superiores à ponta e base dos galhos primários. As concentrações obtidas no ūltimo ano $(53,2 \mathrm{ppm}$ para galhos se cos e 28,0 e 25,3 ppm para ponta e base dos galhos primärios, respectivamente) foram diferentes das obtidas por SHORROCKS (1965a) em ärvores adultas ( 71 ppm para galhos verdes e $37 \mathrm{ppm}$ para os galhos restan tes). 


\subsubsection{Acümulo,}

A variação do acümulo total de ferro na planta em função da idade é apresentada na Tabela 11 . A absorção desse elemento p pe las plantas não variou durante os três primeiros anos, ocorrendo um au mento significativo no quarto ano. Esses resultados divergem dos obti dos por SHORROCKS(1965a), que obteve um grande aumento na absorção do pri meiro para o segundo ano, decrescendo nos anos seguintes. Comparando-se, ainda, os dois trabalhos, nota-se que enquanto esse autor obteve um acümulo de $140 \mathrm{~g} / \mathrm{ha}$ no primeiro ano e $560 \mathrm{~g} / \mathrm{ha}$ no quarto, neste trabaTho obteve-se $18,1 \mathrm{~g} /$ ha no primeiro ano e $140,4 \mathrm{~g} / \mathrm{ha}$ no quarto ano, ou seja, a quantidade obtida por SHORROCKS (1965a) no primeiro ano foi a mesma que a obtida neste trabalho no quarto ano. Essa grande diferença de resultados pode ter sido causada,possivelmente, pela utilização de clones diferentes.

A equação de regressão que melhor se ajustou a variação da quantidade total de ferro em relação à idade foi a quadrätica, assinalada,juntamente com a curva correspondente, na Figura 23.

A Tabela 12 apresenta as variações da quantidade de fer ro nas folhas em função da idade. Não houve variação na absorção do primeiro para o segundo ano, ocorrendo um acréscimo de 6,3 vezes do se gundo para o terceiro ano e de 1,8 vezes do terceiro para o quarto ano. Esse elemento foi o segundo micronutriente mais absorvido pelas folhas, apresentando $85,3 \mathrm{~g} /$ ha no ültimo ano.

Quanto à variação da quantidade de ferro no tronco,apre 
sentada na Tabela 13, nota-se que ocorreram aumentos crescentes na absor ção de ferro com o passar do tempo, sendo que do primeiro para o segundo ano o aumento foi de apenas 1,2 vezes,triplicando do segundo para o terceiro ano, e com cerca de 1,4 vezes do terceiro para o quarto ano. A distribuição da quantidade desse elemento pelo tronco mostrou que houve uma diminuição do teor no sentido base-ponta, provavelmente devi do ao peso de matéria seca da base ser maior que a do meio e ponta. No último ano, a quantidade total acumulada pelo tronco foi de 29,0 g/ha, bem abaixo da acumulada pelas folhas.

Atravēs da Tabela 14, que apresenta a variação da quantidade de ferro nos galhos, observa-se que o aumento do terceiro para o quarto ano foi de 3,7 vezes, quase alcançando a quantidade existente no tronco. Nota-se também que, no ūltimo ano, a base dos galhos primārios apresentou quantidades de ferro bem superiores em relação à ponta, provavelmente devido ao maior peso de matéria seca existente na base, embora essas quantidades tenham sido menores quando comparadas com as dos galhos seços. A quantidade total estimada desse elemento no ültimo ano, apresentada pelos galhos, foi de $26,1 \mathrm{~g} / \mathrm{ha}$.

Considerando a quantidade total de ferro na planta como sendo igual a $100 \%$, a distribuição porcentual desse elemento em cada örgão è apresentada na Figura 24. As folhas apresentaram as mais altas quantidades de ferro,variando de $70,7 \%$ no primeiro ano até $60,8 \%$ no quarto ano, mostrando, portanto, que mais da metade do ferro absorvido pela planta está concentrado nas folhas. No tronco as quantidades são baixas, apresentando $29,3 \%$ no primeiro ano, quase alcançando 
as follhas no segundo ano, com $44,9 \%$, e decrescendo novamente até $20,6 \%$ no quarto ano. Os galtios apresentaram um acümulo de $18,6 \%$ no quar to ano, com uma tendência de ultrapassar o tronco nos anos seguintes. 


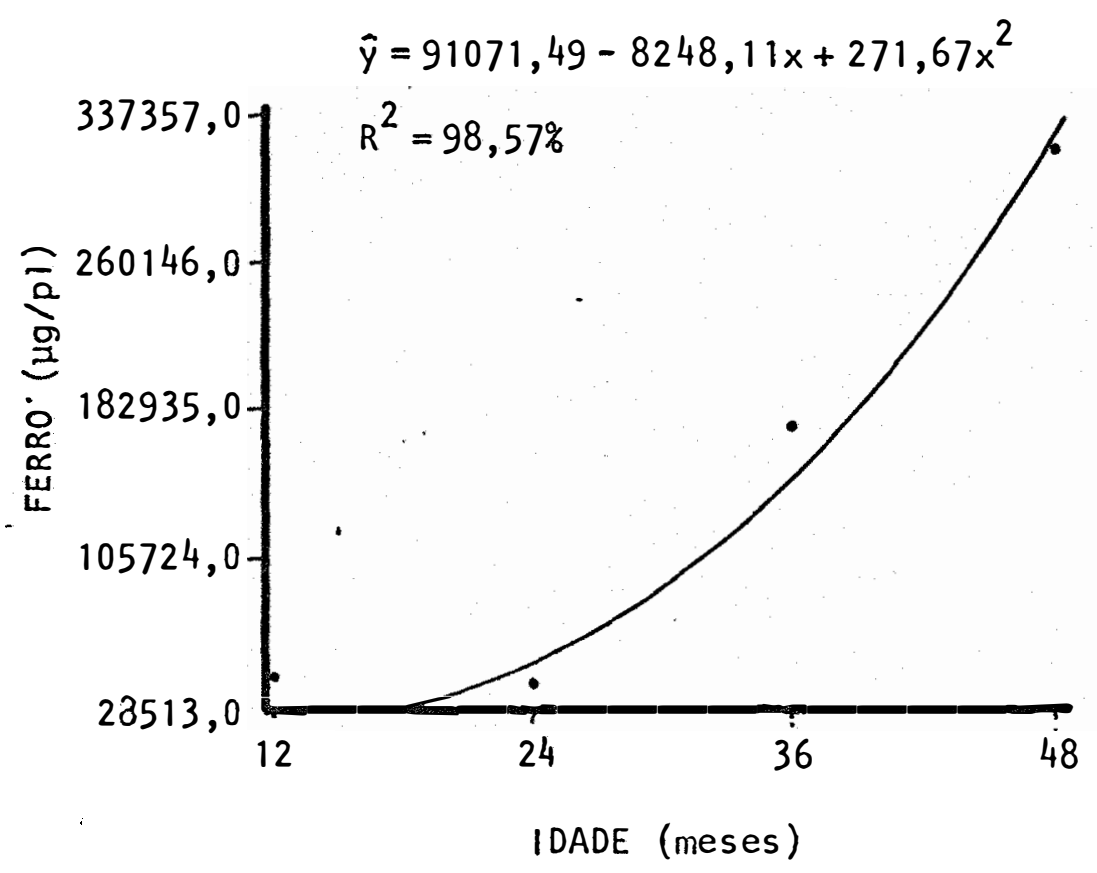

FIGURA 23 - Acúmulo total de ferro na planta, em função da idade.

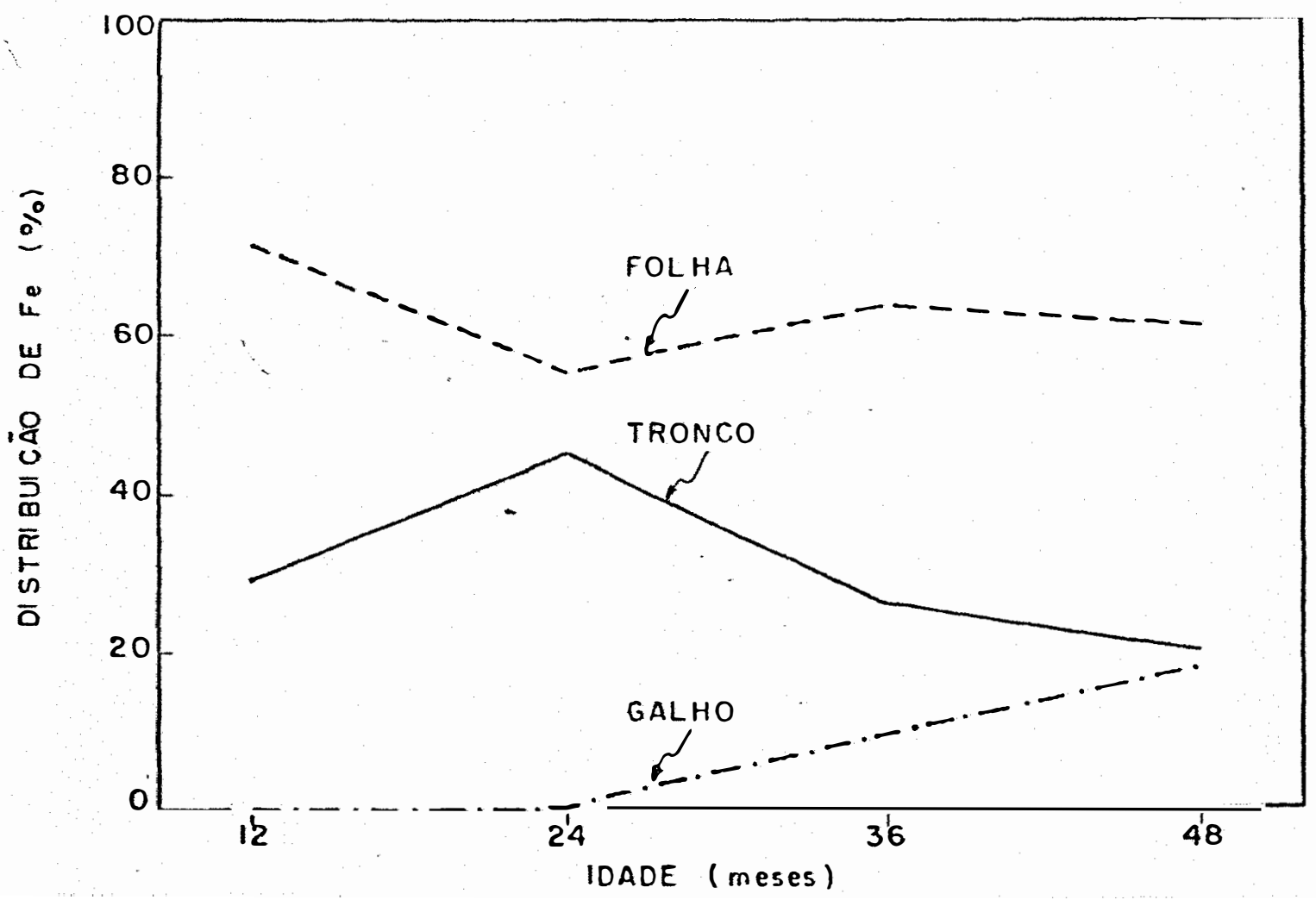

FIGURA 24 - Distribuição de ferro nos diversos órgãos da planta, em função da idade. 


\subsubsection{Manganês.}

\subsubsection{Concentração.}

A concentração de manganēs nas folhas, com base no peso da matēria seca, em função da idade, ē apresentada na Tabela 12. Não se ajustou nenhuma regressão para esse tipo de variação,pois não houve diferenças significativas nas concentrações de manganês durante os qua tro anos. No ūltimo ano, a concentração de manganês na folha $(434,0$ Ppm) foi bem superior à média apresentada por SHORROCKS (1965a) em ärvores adultas (211 $\mathrm{ppm})$.

Atravēs da Tabela 13, que apresenta a concentração de manganês nas diversas partes do tronco em função da idade, nota-se que essa concentração diminuiu com o aumento da idade, com a ponta do tron co apresentando concentrações superiores ao meio e base. 0 quarto ano apresentou uma concentração de 77,5 ppm para a ponta do tronco, três vezes mais que a obtida por SHORROCKS (1965a), ou seja, 25 ppm.

Com relação à concentração de manganês nas diversas partes dos galhos em função da idade, observada na Tabela 14, observa-se que a concentração desse elemento variou do terceiro para o quar to ano, aumentando nos galhos secos e diminuindo na ponta e base dos galhos primärios. Houve diferenças entre as concentrações obtidas nes te trabalho (289,8 ppm para galhos secos e 150,8 e 77,3 ppm para ponta e base dos galhos primärios, respectivamente) e as apresentadas por SHORROCKS (1965a), que obteve 90 ppm para os galhos verdes e 26 ppm para os galhos restantes. 


\subsubsection{Acúmulo}

A Tabela 11 apresenta a quantidade total de manganês a cumulada na planta em função da idade. A absorção desse elemento pelas plantas não variou durante os três primeiros anos, ocorrendo um aumento significativo no quarto ano. Esses resulta dos não diferem muito dos obtidos por SHORROCKS (1965a), pois enquanto esse autor obteve um acúmulo de $140 \mathrm{~g} / \mathrm{ha}$ no primeiro ano e $560 \mathrm{~g} / \mathrm{ha}$ no quarto ano, neste trabalho foi obtido $61,2 \mathrm{~g} / \mathrm{ha}$ no primeiro ano e 436,7 g/ha no quarto ano. Nota-se, tambēm, que o manganès foi o micronutriente mais absorvido pelas plantas, concordando com o autor anterior, embora a adubação realizada com sulfato de manganês tambēm tenha influenciado nesse resultado.

A curva correspondente à variação da quantidade de manganês em relação à idade è apresentada na Figura 25, juntamente com a equação de regressão quadrática, que foi aquela que mais se ajustou a esse tipo de variação.

A quantidade de manganês acumulada pelas folhas, observada na Tabela 12, apresentou aumentos crescentes com o passar do tempo, com pequenos incrementos nos três primeiros anos, mas apresentando um aumento de 2,4 vezes do terceiro para o quarto ano. 0 manganês foi - micronutriente mais acumulado pelas folhas, com um total de $208,9 \mathrm{~g} / \mathrm{h} a$ no ültimo ano, ou seja, 2,5 vezes a mais que o ferro, que foi o segundo mais absorvido. 
Com relação à variação da quantidade de manganês no tronco, apresentada na Tabela 13, observa-se que ocorreram pequenos incrementos nos três primeiros anos, com um aumento de 2,3 vezes do terceiro para o quarto ano. A base do tronco apresentou quantidades supe riores ao meio e à ponta, devido ao seu maior peso de matéria seca.

A variação da quantidade de manganês nas diversas partes dos galhos è apresentada na Tabela 14. Nota-se que houve um aumen to de 6,5 vezes do terceiro para o quarto ano, com os galhos secos apresentando quantidades superiores à ponta dos galhos primários, e estes em relação à sua base.

A distribuição porcentual de manganês em cada órgão da planta, considerando a quantidade total desse elemento na planta como sendo igual a 100\%, è apresentada na Figura 26 . As folhas apresentaram as maiores quantidades de manganês, as quais decresceram com o aumento da idade, variando de $67,0 \%$ no primeiro ano atē $47,8 \%$ no quarto ano. No tronco as quantidades variaram de $33,0 \%$ no primeiro ano, atingindo um máximo de $38,5 \%$ no segundo e decrescendo até $25,1 \%$ no quarto ano. Os galhos apresentaram um grande aumento na quantidade de manga nês com o passar do tempo, com $11,9 \%$ no terceiro e $27,1 \%$ no quarto ano, ultrapassando o tronco nesse ültimo ano. 


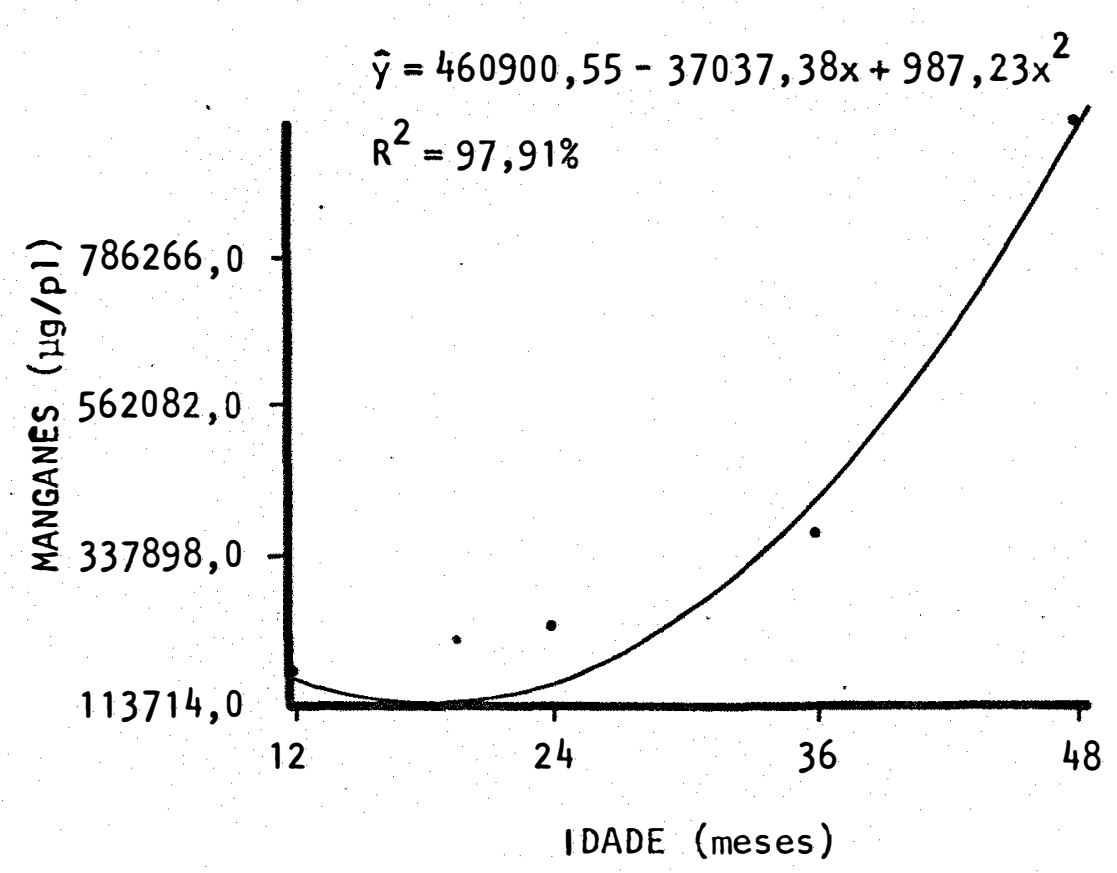

FIGURA 25 - Acümulo total de manganês na planta, em função da idade.

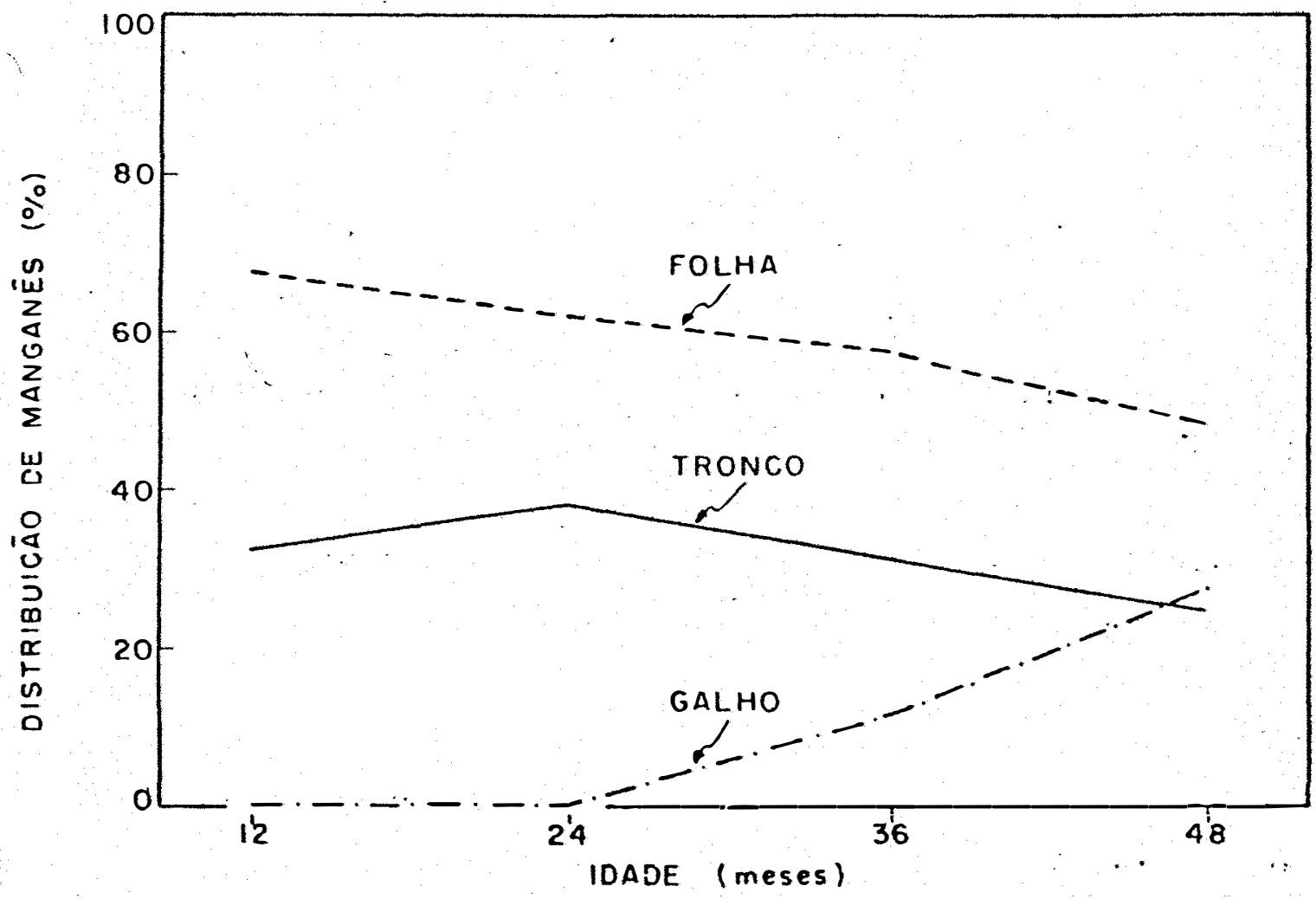

FIGURA 26 - Distribuição de manganês nos diversos örgãos da planta, em função da idade. 


\subsubsection{Zincio}

\subsubsection{Concentração}

Os dados analiticos referentes à concentração de zinco nas folhas com base no peso de matēria seca,em função da idade, são apresentados na Tabela 12. Não houve diferença na concentração dé zin co durante os três primeiros anos, ocorrendo um aumento significativo no quarto ano. Ajustou-se regressão quadrática para esse tipo de variação, estando apresentada, juntamente com a curva correspondente, na Figura 27. No ültimo ano, a concentração de zinco na folha (38,3 ppm) foi bem superior à apresentada por SHORROCKS (1965a) em àrvores adultas (23 ppm).

A concentração de zinco nas diversas partes do tronco, mostrada pela. Tabela 13, não apresentou uma tendência regular com o aumento da idade, sendo que no quarto ano a base do tronco apresentou uma concentração de 14,5 ppm, quase igual à obtida por SHORROCKS (1965a), ou seja, 16 ppm.

A Tabela 14, que apresenta a concentração de zinco nas diversas partes dos galhos em função da idade,mostra que essa concentração variou do terceiro para o quarto ano, aumentando nos galhos secos, permanecendo praticamente a mesma na ponta dos galhos primários e diminuindo na sua base. Houve diferenças entre as concentrações obtidas neste trabalho (23,3 ppm para galhos secos e 18,3 e 12,8 ppm para ponta e base dos galhos primários, respectivamente) e as apresentadas por SHORROCKS (1965a), que obteve 12 ppm para os galhos verdes e 8 
ppm para os galhos restantes.

\subsubsection{Acümulo .}

A quantidade total de zinco acumulada na planta em função da idade encontra-se na Tabela 11. Observa-se que a absorção desse micronutrientes pelas plantas não variou durante os três primeiros anos, ocorrendo um aumento significativo no quarto ano. Esses resulta dos não concordam com os obtidos por SHORROCKS (1965a), que obteve um aumento de 5,5 vezes do primeiro para o segundo ano, diminuindo nos anos seguintes. Comparando-se, ainda, esses dois trabalhos, observa-se que enquanto nas condições do Acre a seringueira absorveu 3,2 g/ha no primeiro ano e 52,2 g/ha no quarto ano, na Malásia essa planta absorveu $20 \mathrm{~g} / \mathrm{ha}$ no primeiro ano e $570 \mathrm{~g} / \mathrm{ha}$ no quarto ano. Essas grandes diferenças na absorção de zinco,provavelmente, devem ter sido causadas pela utilização de clones diferentes nos dois experimentos.

A equação de regressão que melhor se ajustou à variação da quantidàde total de zinco em relação à idade foi a quadrática, assinalada,juntamente com a curva correspondente, na Figura 28.

0 acúmulo de zinco nas folhas, mostrado na Tabela 12, praticamente não variou do primeiro para o segundo ano, aumentando 2,7 vezes do segundo para o terceiro ano e 3,6 vezes do terceiro para o quarto ano, sendo que no ültimo ano as folhas apresentaram uma quantida de estimada de $18,9 \mathrm{~g} / \mathrm{ha}$.

A Tabela 13 apresenta o acúmulo de zinco no tronco em 
função da idade. Houve um grande aumento do primeiro para o segundo ano, com cerca de 3,6 vezes, aumentando muito pouco do segundo para o terceiro ano e apresentando, novamente, um grande aumento do terceiro para o quarto ano, com cerca de 3,5 vezes. A base do tronco apresentou quantidades superiores ao meio e à ponta, sendo que no ültimo ano a quantidade total acumulada pelo tronco foi de $21,1 \mathrm{~g} / \mathrm{ha}$, superior à apresentada pelas folhas.

Quanto à variação da quantidade de zinco nos galhos, apresentada na Tabela 14, nota-se que houve um grande aumento do terceiro para o quarto ano, com cerca de 7,8 vezes. No quarto ano os gaIhos secos apresentaram quantidades superiores à ponta e base dos galhos primários, sendo que a quantidade total acumulada pelos galhos nes se ano foi de $12,4 \mathrm{~g} / \mathrm{ha}$, inferior às acumuladas pelas folhas e tronco.

Considerando a quantidade total de zinco na planta como sendo igual a 100\%, a distribuição porcentual desse elemento em cáda örgão ë apresentada na Figura 29. 0 tronco apresentou as maiores quan tidades de zinco em relação aos outros órgãos, com excessão do primeiro ano. Nesse ano, o tronco apresentou $46,9 \%$, atingindo um máximo de 74,0\% no segundo ano e decrescendõ até $40,4 \%$ no quarto ano. As fol has apre sentaram quantidades superiores ao tronco no primeiro ano com cerca de $53,1 \%$, decrescendo para $35,8 \%$ no quarto ano, e com uma tendência de ul trapassar as quantidades existentes no tronco nos pröximos anos. Os ga Ihos apresentaram uma porcentagem de $12,4 \%$ no terceiro ano e $23,8 \%$ no quarto, tambëm com tendência de ultrapassar as quantidades existen tes nas folhas e tronco nos anos seguintes. 


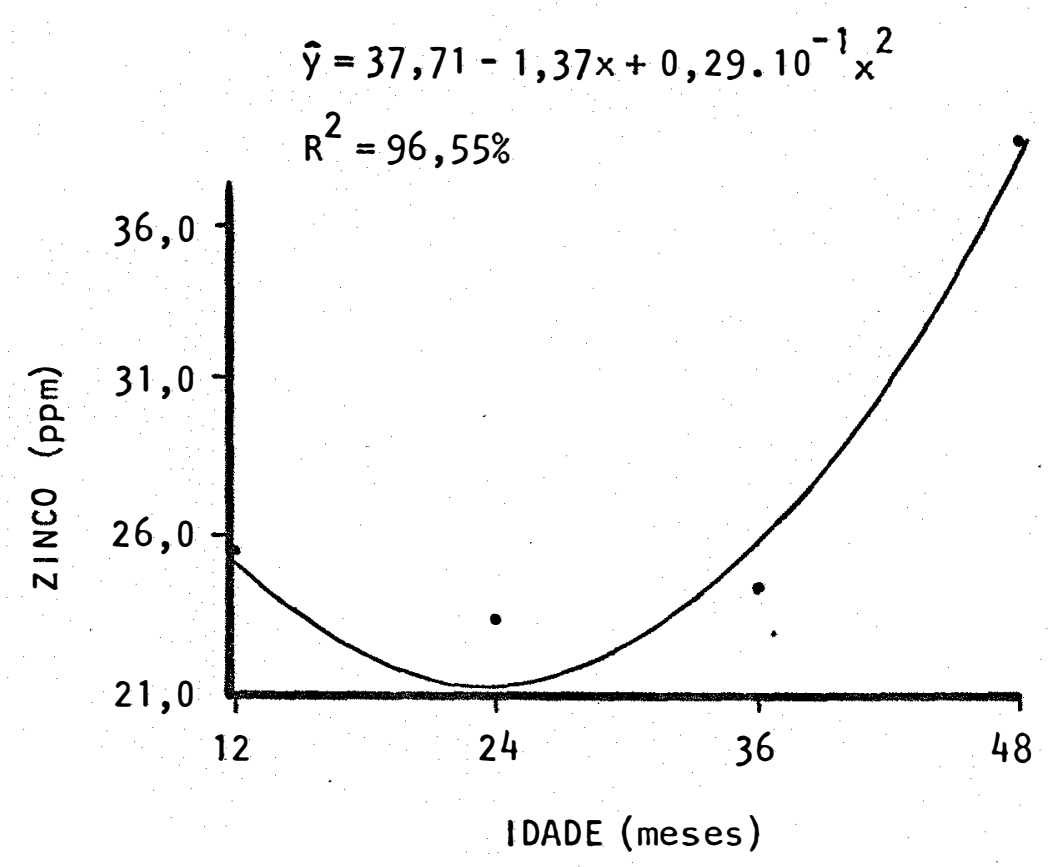

FIGURA 27 - Concentração de zinco nas folhas, em função da idade.

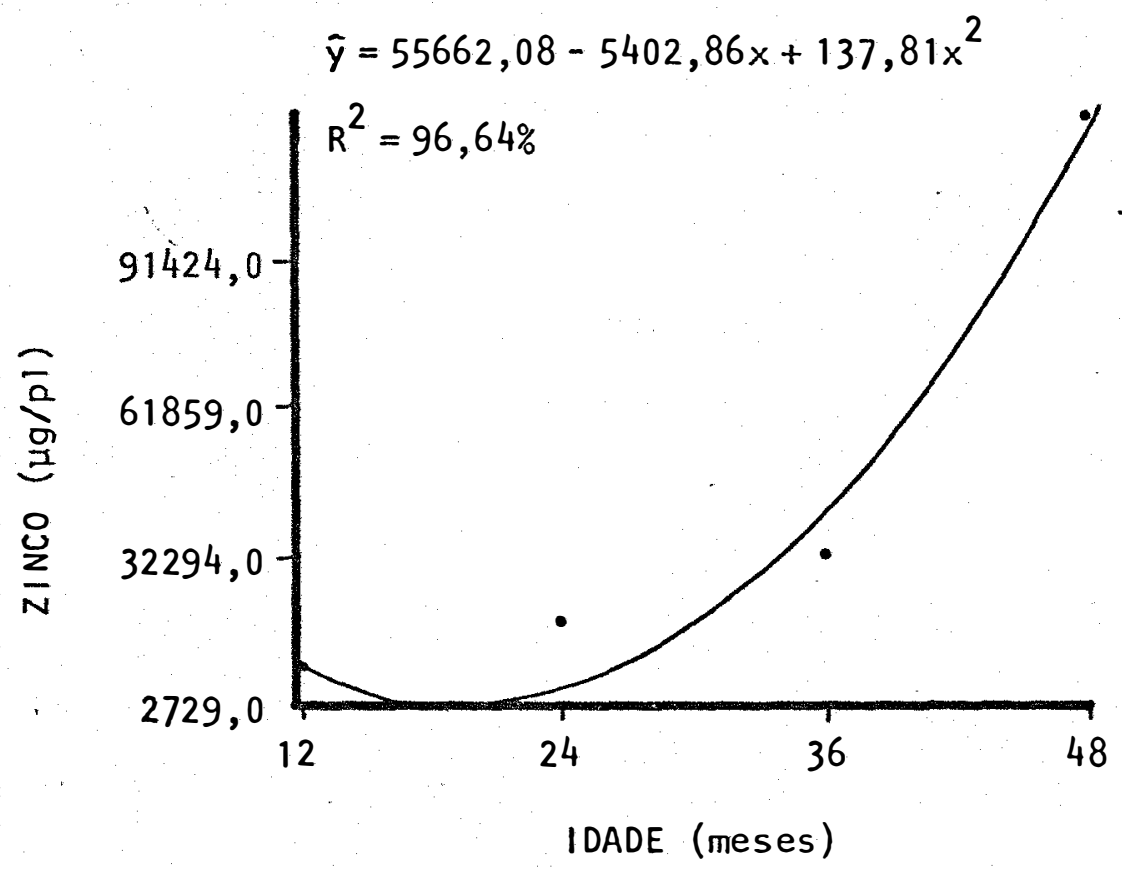

FIGURA 28 - Acümulo total de zínco na planta, em função da idade. 


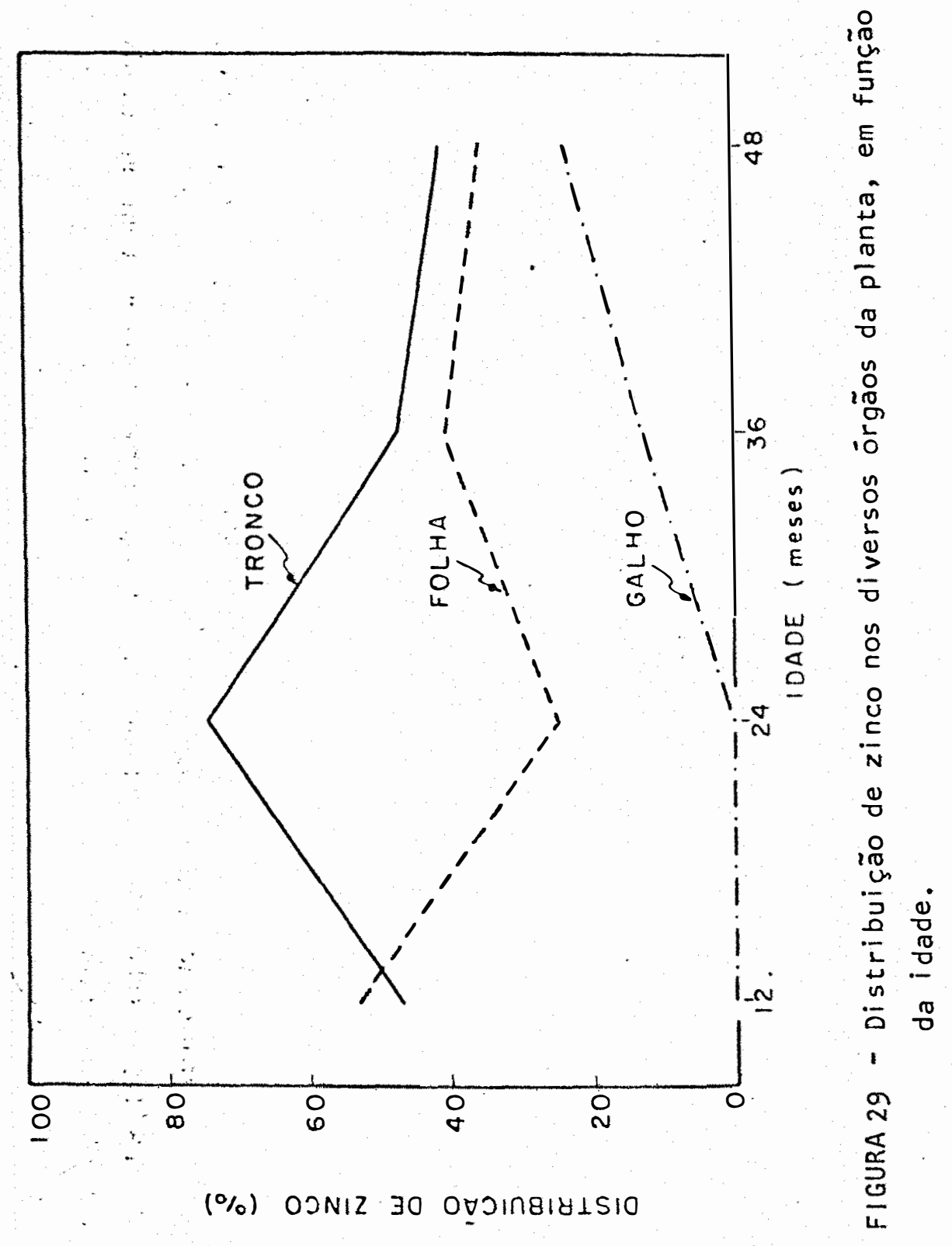


4.4. Extração de nutrientes pela cobertura verde e nutrientes contidos na cobertura morta.

Os estudos têm demonstrado que a cobertura com leguminosas contribui para aumentar o teor de nitrogênio no solo, beneficiando grandemente o desenvolvimento da seringueira. Na área da BONAL S.A., a leguminosa utilizada para esse fim è a Pueraria phaseoloides, recomendada pela EMBRATER/EMBRAPA (1980). Foi coletada uma amostra do terceiro e outra do quarto ano para se fazer a avaliação das quantidades de nutri entes absorvidas pela leguminosa. Essas amostras não são bem representa tivas da ärea, mas servem para dar uma idéia da quantidade de nutrientes retirada do solo. Os resultados estão apresentados nas Tabelas 15 e 16 .

A matëria seca proporcionada pela leguminosa foi superior à da seringueira, duplicando do terceiro para o quarto ano. Nota-se tambèm que a leguminosa absorveu grande quantidade de nutrientes, superando a absorvida pela pröpria seringueira. Dentre os macronutrientes, os mais absorvidos foram o potāssio e o nitrogênio, seguidos de longe pelo cálcio. Portanto, o nitrogênio, alēm de ser fixado pela leguminosa e colocado à disposição para ser absorvido pela seringueira, também è absorvido em grandes quantidades pela prōpria leguminosa.

Comparando-se as quantidades absorvidas pela leguminosa no terceiro e quarto anos, observa-se um incremento de 1,5 vezes para o nitrogênio, de 2,0 vezes para o fösforo e potāssio, de 1,8 vezes para o cālcio; de 1,6 vezes para o magnēsio e de quase 10 vezes para o enxofre. Este ültimo dado è muito importante, pois o enxofre, sendo um elemento encontrado em pequenas quantidades nos solos amazônicos, ficarāainda menos disponivel para a seringueira. 
TABELA 15 - Quantidade de macronutrientes e peso de matéria seca acumula dos pela cobertura verde no terceiro e quarto anos.

\begin{tabular}{|c|c|c|c|c|c|c|c|}
\hline \multirow{2}{*}{$\begin{array}{c}\text { Idade } \\
\text { (meses) }\end{array}$} & \multirow{2}{*}{$\begin{array}{c}\text { Peso de } \\
\text { Matéria Seca } \\
(\mathrm{kg} / \mathrm{ha})^{\star}\end{array}$} & \multicolumn{6}{|c|}{ Nutrientes } \\
\hline & & N & $P$ & K & $\mathrm{Ca}$ & $\mathrm{Mg}$ & $S$ \\
\hline 36 & 1643,5 & 29,26 & 1,97 & 41,09 & 11,67 & 5,26 & 0,33 \\
\hline 48 & 3185,5 & 43,32 & 4,14 & 79,64 & 21,34 & 8,60 & 3,19 \\
\hline
\end{tabular}

Os cálculos foram feitos supondo que a leguminosa cubra $50 \%$ da área, estando descontado o espaço limpo deixado ao redor das árvores.

TABELA 16 - Quantidade de micronutrientes acumulada pela cobertura verde no terceiro e quarto anos.

\begin{tabular}{|c|c|c|c|c|c|}
\hline \multirow{2}{*}{$\begin{array}{c}\text { Idade } \\
\text { (meses) }\end{array}$} & \multicolumn{5}{|c|}{ Nutrientes ( $g / h a)$} \\
\hline & B & $\mathrm{Cu}$ & $\mathrm{Fe}$ & Mn & $2 n$ \\
\hline 36 & 34,5 & 54,3 & 2531,0 & 611,4 & 78,9 \\
\hline 48 & 217,4 & 60,5 & 3121,8 & 1277,4 & 140,2 \\
\hline
\end{tabular}


Quanto aos micronutrientes, os mais absorvidos foramofer ro e o manganês, apresentando uma absorção altíssima no quarto ano. Embora os outros micronutrientes tenham sido absorvidos em quantidades menores em relação a esses dois, quando essas quantidades são comparadas com as absorvidas pela seringueira, nota-se que foram bem superiores, con tribuindo ainda mais para o empobrecimento do solo.

Com relação aos incrementos obtidos do terceiro para o quarto ano para os micronutrientes, nota-se que o boro apresentou 0 maior aumento, com cerca de 3,7 vezes. Já o manganês, duplicou a sua quantidade, enquanto o zinco teve um aumento de 1,8 vezes. Os incrementos obtidos na absorção de cobre e ferro foram muito pequenos.

Ao mesmo tempo em que foram coletadas as amostras da legu minosa, coletou-se uma amostra do terceiro e outra do quarto ano da cobertura morta existente sobre o solo. Essa cobertura morta é constituída por folhas e galhos de seringueira, alēm de plantas mortas da leguminosa, formando a manta orgânica do solo. Os resultados das análises estão nas Tabela 17 e 18 .

Observa-se que a matēria seca produzida pela coberturamor ta foi extremamente alta, embora aumente apenas de 1,2 vezes do terceiro para o quarto ano. Deve-se salientar, entretanto, que esses resultados são provenientes de apenas uma amostra da cobertura morta, não representando efetivamente a ärea em estudo, mas servindo para se ter uma idéia das quantidades de matéria seca e nutrientes nela contidas. 
TABELA 17 - Quantidade de macronutrientes e peso de matēria seca acumula dos pela cobertura morta, no terceiro e quarto anos.

\begin{tabular}{|c|c|c|c|c|c|c|c|}
\hline \multirow{2}{*}{$\begin{array}{c}\text { Idade } \\
\text { (meses) }\end{array}$} & \multirow{2}{*}{$\begin{array}{c}\text { Peso de } \\
\text { Matéria Seca } \\
(\mathrm{kg} / \mathrm{ha})^{*}\end{array}$} & \multicolumn{6}{|c|}{ Nutrientes } \\
\hline & & N & $P$ & $K$ & $\mathrm{Ca}$ & $\mathrm{Mg}$ & $S$ \\
\hline 36 & 5031,5 & 104,50 & 3,20 & 21,86 & 49,58 & 14,93 & 5,87 \\
\hline 48 & 5912,5 & 95,78 & 3,55 & 27,20 & 41,98 & 16,56 & 4,32 \\
\hline
\end{tabular}

* Os călculos foram feitos supondo que a cobertura morta cubra $50 \%$ da ärea, estando descontado o espaço limpo deixado ao redor das árvores.

TABELA 18 - Quantidade de micronutrientes acumulada pela cobertura morta, no terceiro e quarto anos.

\begin{tabular}{|c|c|c|c|c|c|}
\hline \multirow{2}{*}{$\begin{array}{c}\text { Idade } \\
\text { (meses) }\end{array}$} & \multicolumn{2}{|c|}{ - } & \multicolumn{3}{|c|}{ Nutrientes $(\mathrm{g} / \mathrm{ha})$} \\
\hline & B & $\mathrm{Cu}$ & $\mathrm{Fe}$ & $M n$ & $Z n$ \\
\hline 36 & 117,3 & 149,3 & 47738,3 & 1839,4 & 202,6 \\
\hline 48 & 189,2 & 106,5 & 31673,3 & 5007,9 & 207,0 \\
\hline
\end{tabular}


Com relação aos nutrientes existentes na cobertura morta, pode-se observar as quantidades altíssimas, tanto dos macro como dos micronutrientes, superando em muito as quantidades absorvidas pela seringueira. Deve ser ressaltado que essa grande quantidade de nutrientes näo estā disponível de imediato à seringueira, pois está retida na manta orgânica. Esta estā sujeita a um grande número de fatores, dos quais resultam a sua decomposição atē-uma consequente mineralização do material ó gânico e liberação dos elementos minerais, podendo ser fonte de nutrientes para a vegetação que nela se desenvolve e estabelecendo uma ciclagem de nutrientes: manta-solo-planta.

Observando-se as quantidades de nutrientes existentes na manta orgânica, nota-se que alguns elementos, tanto macro como micronutrientes, apresentaram-se em maiores quantidades no terceiro ano em rela ção ao quarto ano. Isso pode ter sido causado pela falta de repetições na amostragem. 


\subsection{Extração total de nutrientes.}

A Tabela 19 apresenta a quantidade total de nutrientes ab sorvida pela seringueira em função da sua idade. Inicialmente, a absorção de nutrientes foi lenta, aumentando apenas 1,4 vezes do primeiro para o segundo ano. Entretanto, o incremento na absorção foi de cerca de 2,7 vezes do segundo para o terceiro ano e de 3,0 vezes do terceiro para o quarto ano. Portanto, nota-se que houve maior absorção com o passar do tempo.

Comparando-se a extração total de nutrientes como peso de matēria seca, tem-se que essa relação praticamente não variou durante os quatro anos, com o peso de nutrientes sendo $2,3 \%$ em relação ao peso de ma téria seca. Portanto, nota-se que o aumento na absorção de nutrientes pela seringueira foi proporcional ao aumento da matéria seca. Essa rela ção é vālida somente até certo ponto, pois com o passar do tempo, a seringueira, assim como todas as plantas, tende a estabilizar o seu cresci mento, embora continue absorvendo nutrientes no solo.

A Tabela 20 apresenta os acréscimos porcentuais de nutrientes em função da idade. Os acréscimos porcentuais do primeiro para o segundo ano foram baixos, com cerca de $155,6 \%$ em média. Do segundo para o terceiro ano, os acréscimos já foram maiores, com aumento de $400,7 \%$. Agora, do terceiro para o quarto ano, os acréscimos foram excepcionais, com uma média de $1147,5 \%$. 
TABELA 19 - Quantidade de nutrientes contidos em 446 ärvores por hectare.

\begin{tabular}{|c|c|c|c|c|c|}
\hline \multirow{2}{*}{ Nutrientes } & \multirow{2}{*}{ Un idade } & \multicolumn{4}{|c|}{ Idade (meses) } \\
\hline & & 12 & 24 & 36 & 48 \\
\hline N & $\mathrm{kg}$ & 2,29 & 2,87 & 8,81 & 24,54 \\
\hline$P$ & $\mathrm{~kg}$ & 0,19 & 0,27 & 0,63 & 1,82 \\
\hline K & $\mathrm{kg}$ & 1,79 & 1,77 & 5,61 & 18,29 \\
\hline $\mathrm{Ca}$ & $\mathrm{kg}$ & 0,78 & 1,69 & 3,56 & 11,07 \\
\hline $\mathrm{Mg}$ & $\mathrm{kg}$ & 0,43 & 0,90 & 1,50 & 5,29 \\
\hline$S$ & $\mathrm{~kg}$ & 0,14 & 0,29 & 0,77 & 1,88 \\
\hline$B$ & $g$ & 3,7 & 3,8 & 19,0 & 29,4 \\
\hline $\mathrm{Cu}$ & $g$ & 1,1 & 1,7 & 4,9 & 18,3 \\
\hline $\mathrm{Fe}$ & $\mathrm{g}$ & 18,1 & 13,8 & 75,1 & 140,4 \\
\hline$M n$ & $g$ & 61,2 & 91,6 & 152,7 & 436,7 \\
\hline $2 n$ & $g$ & 3,2 & 7,3 & 12,9 & 52,2 \\
\hline Total & $\mathrm{kg}$ & 5,71 & 7,91 & 21,14 & 63,57 \\
\hline $\begin{array}{l}\text { Peso de } \\
\text { Matēria Seca }\end{array}$ & $\mathrm{kg}$ & $242,7^{\circ}$ & 346,1 & 949,0 & 2785,6 \\
\hline $\begin{array}{l}\text { Nutrientes em } \\
\text { Relação à } \\
\text { Matéria Seca }\end{array}$ & $\%$ & $\begin{array}{r}2,4 \\
-\quad\end{array}$ & 2,3 & 2,2 & 2,3 \\
\hline
\end{tabular}


TABELA 20 - Acrēscimos porcentuais da absorção de nutrientes em função da idade.

\begin{tabular}{ccccc}
\hline Nutrientes & \multicolumn{4}{c}{ Idade (meses) } \\
\cline { 2 - 5 } $\mathrm{N}$ & 12 & 24 & 36 & 48 \\
\hline $\mathrm{P}$ & 100,0 & 125,3 & 384,7 & 1071,6 \\
$\mathrm{~K}$ & 100,0 & 142,1 & 331,6 & 957,9 \\
$\mathrm{Ca}$ & 100,0 & 98,9 & 313,4 & 1021,8 \\
$\mathrm{Mg}$ & 100,0 & 216,7 & 456,4 & 1419,2 \\
$\mathrm{~S}$ & 100,0 & 209,3 & 348,8 & 1230,2 \\
$\mathrm{~B}$ & 100,0 & 207,1 & 550,0 & 1342,9 \\
$\mathrm{Cu}$ & 100,0 & 102,7 & 513,5 & 794,6 \\
$\mathrm{Fe}$ & 100,0 & 154,5 & 445,5 & 1663,6 \\
$\mathrm{Mn}$ & 100,0 & 76,2 & 414,9 & 775,7 \\
$\mathrm{Zn}$ & 100,0 & 149,7 & 249,5 & 713,6 \\
& 100,0 & 228,1 & 403,1 & 1631,3 \\
\hline
\end{tabular}


Esse tipo de estudo é mui to importante para se acompanhar a necessidade de adubação. No quarto ano, por exemplo, quase todos os ma cronutrientes, exceção feita ao fósforo, sofreram um acrēscimo de absorção superior a $1000 \%$ em relação ao primeiro ano, devendo esta ser uma ēpoca de adubação pesada para evitar problemas futuros de deficiência.

No caso do cálcio e magnésio, devido ao tipo de solo da ă rea da BONAL S.A. ser muito äcido e com baixa porcentagem de saturação de bases (como pode ser visto pela anālise do solo), sendo, portanto, um so lo pobre em nutrientes, e aliado à grande absorção pela seringueira, nota-se a necessidade de se fazer um estudo mais profundo de calagem, näo só para repor esses dois nutrientes, como tambēm para elevar o pH desse solo, aumentando a disponibilidade dos outros elementos às plantas.

0 enxofre também. foi um elemento que sofreu um grande acréscimo porcentual de absorção no quarto ano, com cerca de $1342,9 \%$. De vido ao fato dos solos amazônicos serem muito pobres nesse elemento, tor nando-se até fator limitante para certas culturas, nota-se a necessidade de se utilizar adubos contendo enxofre em sua fórmula para supriressa ca rência.

Quanto aos micronutrientes, deve-se dar maior importância ao cobre e ao zinco (sem desprezar os outros, entretanto), pois são os que apresentaram maiores acréscimos porcentuais no quarto ano, ultrapassando a casa dos $1600 \%$. Porcentualmente, esses dois elementos são os mais absorvidos dentre todos os macro e micronutrientes, podendo tornar-se fa tores limitantes para o desenvolvimento da seringueira, caso não sejam devolvidos ao solo através de adubações. 
A extração total de nutrientes do solo, somando-se as quan tidades retiradas apenas no quarto ano pela seringueira e coberturas ver de e morta, è apresentada na Tabela 21. Pode-se notar a grande quantidade de nutrientes extraida do solo por essas coberturas. Das quantidades extraídas, uma parte deveră retornar ao solo, que corresponde aos nutrientes contidos na cobertura morta. Em termos de porcentagem, serão restituidos ao solo: $58,5 \%$ de $\mathrm{N} ; 37,3 \%$ de $\mathrm{P} ; 21,7 \%$ de $\mathrm{K} ; 56,4 \%$ de Ca; $54,4 \%$ de Mg; $51,2 \%$ de S; $54,7 \%$ de B; $57,5 \%$ de $\mathrm{Cu} ; 90,7 \%$ de Fe; $74,5 \%$ de $\mathrm{Mn}$ e $51,8 \%$ de $\mathrm{Zn}$.

Deve ser ressaltado que essa grande devolução de nutrientes ao solo, além de processar-se apenas a longo prazo, não será total mente aproveitada pela seringueira. Isto porque uma parte será consumida pelos microorganismos, outra sofrerä lixiviação, outra será absorvida pela leguminosa, além de ocorrerem outras perdas. Mas, embora isto acon teça, uma boa parte dos nutrientes ficaráa disposição da seringueira, o que deverá diminuir os gastos com adubação, que, entretanto, é imprescin divel. 
TABELA 21 - Extração total de nutrientes do solo.

\begin{tabular}{|c|c|c|c|c|c|}
\hline \multirow{2}{*}{ Nutrientes } & \multirow{2}{*}{ Unidade } & \multicolumn{2}{|r|}{ Quantidade } & \multicolumn{2}{|l|}{ Extraída } \\
\hline & & Seringuei ra & Leguminosa & $\begin{array}{c}\text { Cobertura } \\
\text { Morta }\end{array}$ & Total \\
\hline $\mathbf{N}$ & $\mathrm{kg}$ & 24,54 & 43,32 & 95,78 & 163,64 \\
\hline$P$ & kg & . 1,82 & $4,14^{\circ}$ & 3,55 & 9,51 \\
\hline$K$ & $\mathrm{~kg}$ & 18,29 & 79,64 & 27,20 & 125,13 \\
\hline $\mathrm{Ca}$ & $\mathrm{kg}$ & 11,07 & 21,34 & 41,98 & 74,39 \\
\hline $\mathrm{Mg}$ & $\mathrm{kg}$ & 5,29 & 8,60 & 16,56 & 30,45 \\
\hline $\mathbf{S}$ & $\mathrm{kg}$ & 1,88 & 3,19 & 5,32 & 10,39 \\
\hline B & $\mathrm{g}$ & 29,4 & 127,4 & 189,2 & 346,0 \\
\hline $\mathrm{Cu}$ & $g$ & 18,3 & 60,5 & 106,5 & 185,3 \\
\hline $\mathrm{Fe}$ & $g$ & 140,4 & 3121,8 & 31673,3 & 34935,5 \\
\hline$M n$ & $g$ & 436,7 & 1277,4 & 5007,9 & 6722,0 \\
\hline$Z n$ & $g$ & 52,2 & 140,2 & 107,0 & 399,4 \\
\hline
\end{tabular}


5. CONCLUSOES

\section{Crescimento}

0 período de crescimento mais intenso da seringueira ocor reu a partir do terceiro ano.

As folhas apresentaram, proporcionalmente, uma alta porcentagem de matéria seca em relação ao total $(17,87 \%)$.

\section{Concentração de nutrientes.}

As folhas apresentaram as maiores concentrações de nutrientes, exceto para o cobre.

As concentrações de $P, C a, B, F e$ e Mn nas folhas não variaram com a idade, enquanto que as de $N, K$ e $Z n$ variaram quadraticamente e as de $\mathrm{Mg}$, S e Cu variaram linearmente.

\section{Extração de nutrientes.}

A quantidade de nutrientes extraida pela seringueira, por 
hectare, no quartó ano, foi a seguinte:

Macronutrientes: $24,54 \mathrm{~kg}$ de $\mathrm{N}, 1,82 \mathrm{~kg}$ de $\mathrm{P}, 18,29 \mathrm{~kg}$ de $\mathrm{K}, 11,07 \mathrm{~kg}$ de $\mathrm{Ca}, 5,29 \mathrm{~kg}$ de $\mathrm{Mg} \mathrm{e} 1,88 \mathrm{~kg}$ de $\mathrm{S}$.

Micronutrientes: $29,4 \mathrm{~g}$ de $\mathrm{B}, 18,3 \mathrm{~g}$ de $\mathrm{Cu}, 140,4 \mathrm{~g}$ de $\mathrm{Fe}, 436,7 \mathrm{~g}$ de Mn e 52,2 g de $Z n$.

Os acréscimos percentuais de absorção de nutrientes do prí meiro ao quarto ano, em ordem crescente, foram os seguinte: Mn - $713,6 \%$, $\mathrm{Fe}-775,7 \%, \quad B-794,6 \%, \quad P-957,9 \%, \quad K-1021,8 \%, N-1071,6 \%, \quad M g-$ $1230,2 \%$, S $-1342,9 \%$, Ca $-1419,2 \%, \quad$ n $-1631,3 \%$ e Cu $-1663,6 \%$.

A porcentagem de nutrientes nas folhas em relação à quantidade total acumulada pela planta no quarto ano, em ordem crescente, foi a seguinte: $\mathrm{Cu}-26,8 \%, \mathrm{~K}-30,9 \%, \mathrm{Ca}-32,0 \%, \mathrm{Mg}-34,7 \%, \mathrm{Zn}-35,8 \%$, $S-40,1 \%, \quad P-44,7 \%, \quad B-46,9 \%, \quad M n-47,8 \%, N-56,4 \%, \quad F e-60,8 \%$.

\section{Extração de nutrientes pela leguminosa.}

A quantidade de nutrientes extraída pela leguminosa, por hectare, no quarto ano, foi a seguinte:

Macronutrientes: $43,32 \mathrm{~kg}$ de N, 4,14 kg de P, $79,64 \mathrm{~kg}$ de $\mathrm{K}, \quad 21,34 \mathrm{~kg}$ de $\mathrm{Ca}, 8,60 \mathrm{~kg}$ de $\mathrm{Mg}$ e $3,19 \mathrm{~kg}$ de $\mathrm{S}$.

Micronutrientes: $127,4 \mathrm{~g}$ de B, $60,5 \mathrm{~g}$ de $\mathrm{Cu}, 3131,8 \mathrm{~g}$ de $\mathrm{Fe}, 1277,4 \mathrm{~g}$ de Mn e $140,2 \mathrm{~g}$ de $\mathrm{Zn}$. 


\section{Nutrientes contidos na cobertura morta}

A quantidade de nutrientes contida por hectare, no quarto ano, fioi a seguinte:

Macronutrientes: $95,78 \mathrm{~kg}$ de $\mathrm{N}, 3,55 \mathrm{~kg}$ de $P, 27,20 \mathrm{~kg}$ de $\mathrm{K}, \quad 41,98 \mathrm{~kg}$ de $\mathrm{Ca}, 16,56 \mathrm{~kg}$ de $\mathrm{Mg}$ e $5,32 \mathrm{~kg}$ de $\mathrm{S}$.

Micronutrientes: $189,2 \mathrm{~g}$ de B, $106,5 \mathrm{~g}$ de $\mathrm{Cu}, 31673,3 \mathrm{~g}$ de $\mathrm{Fe}, 5007,9 \mathrm{~g}$ de Mn e 207,0 g de $\mathrm{Zn}$.

\section{Extração total de nutrientes pelo sistema.}

A quantidade total de nutrientes extraída do solo, por hec tare, no quarto ano, foi a seguinte:

Macronutrientes: $163,64 \mathrm{~kg}$ de $\mathrm{N}, 9,51 \mathrm{~kg}$ de $P, 125,13 \mathrm{~kg}$ de $\mathrm{K}, 74,39 \mathrm{~kg}$ de $\mathrm{Ca}, 30,45 \mathrm{~kg}$ de $\mathrm{Mg}$ e $10,39 \mathrm{~kg}$ de $\mathrm{S}$.

Micronutrientes: $346,0 \mathrm{~g}$ de $\mathrm{B}, \quad 185,3 \mathrm{~g}$ de $\mathrm{Cu}, \quad 34935,5 \mathrm{~g}$ de Fe, 6722,0 $\mathrm{g}$ de $\mathrm{Mn}$ e $399,4 \mathrm{~g}$ de $\mathrm{Zn}$.

\section{Ciclagem de nutrientes no sistema.}

Da quantidade total de nutrientes extraída do solo, a porcentagem que será restituída através da cobertura morta, em ordem crescen te, è a seguinte: $K-21,7 \%, P-37,3 \%, S-51,2 \%, \quad \mathrm{n}-51,8 \%, \mathrm{Mg}-54,4 \%$, $\mathrm{B}-54,7 \%, \mathrm{Ca}-56,4 \%, \mathrm{Cu}-57,5 \%, \mathrm{~N}-58,5 \%, \mathrm{Mn}-74,5 \%$ e $\mathrm{Fe}-90,7 \%$. 


\section{LITERATURA CITADA}

BEAUFILS, E.R., 1955. Mineral diagnosis of some Hevea brasiliensis. Archs. Rubber Cult., 32: 1 .

BOLLE-JONES, E.W. e K. RATNASINGAM, 1954. Nutrition of Hevea brasiliensis. IV. Interclonal and seasonal variation in composition of leaves. Journal of the Rubber Research Institute of Malaysia, Kuala Lumpur, 14: 257 .

BRASIL. Departamento Nacional da Produção Mineral. Projeto RADAMBRASIL, 1976. Folha SC. 19 Rio Branco: geologia, geomorfologia, pedologia, vegetação e uso potencial da terra. Rio de Janeiro. v. 12.

EMBRATER, 1979. Manual tēcnico: cultura da seringueira. Brasília. 218 p. (Manuais, 9).

EMBRATER/EMBRAPA, 1980. Sistemas de produção para a cultura da seringueira. no Estado do Amazonas. Manaus. 104 p. (Boletim 189). 